\title{
An angler and creel survey of the walleye (Sander vitreus ) fishery at Summersville Reservoir, West Virginia
}

Dustin Shane Wichterman
West Virginia University

West Virginia University

Follow this and additional works at: https://researchrepository.wvu.edu/etd

\section{Recommended Citation}

Wichterman, Dustin Shane, "An angler and creel survey of the walleye (Sander vitreus ) fishery at Summersville Reservoir, West Virginia" (2011). Graduate Theses, Dissertations, and Problem Reports. 3297.

https://researchrepository.wvu.edu/etd/3297

This Thesis is protected by copyright and/or related rights. It has been brought to you by the The Research Repository @ WVU with permission from the rights-holder(s). You are free to use this Thesis in any way that is permitted by the copyright and related rights legislation that applies to your use. For other uses you must obtain permission from the rights-holder(s) directly, unless additional rights are indicated by a Creative Commons license in the record and/ or on the work itself. This Thesis has been accepted for inclusion in WVU Graduate Theses, Dissertations, and Problem Reports collection by an authorized administrator of The Research Repository @ WVU. For more information, please contact researchrepository@mail.wvu.edu. 
An angler and creel survey of the walleye (Sander vitreus) fishery at Summersville Reservoir, West Virginia

Dustin Shane Wichterman

Thesis Submitted to the Davis College of Agriculture, Natural Resources, and Design

at West Virginia University

in partial fulfillment of the requirements

for the degree of

Master of Science

in

Wildlife and Fisheries Resources

Stuart A. Welsh, Ph. D., Chair

George Merovich, Ph. D

David Wellman, M.S.

Division of Forestry and Natural Resources

Morgantown, WV

2011

Key Words: Angler Creel Survey, Catch and Harvest Rates, Summersville Lake, WV, Human Dimensions, Demographics, Angler Satisfaction 


\begin{abstract}
An angler and creel survey of the walleye (Sander vitreus) fishery at Summersville Reservoir, West Virginia
\end{abstract}

Dustin Shane Wichterman

\begin{abstract}
Catch and harvest information and angler attitudes are important for management of the walleye fishery of Summersville Reservoir, WV, especially given previous estimates of high harvest proportions and low growth rates of walleyes. I used data from angler and creel surveys from November 28, 2008-October 31, 2009 to estimate monthly catch rates, harvest rates, total effort, and total catch of walleyes. Estimates were partitioned by boat anglers, bank anglers, anglers targeting walleyes, and all anglers. Also, angler attitudes were documented for fishing trip satisfaction and the sizes of "keepable" and trophy fish. A total of 84 survey days yielded 165 interviews (111 boat anglers, and 54 bank anglers). Boat angler surveys mostly represented completed trips (98 of 111 interviews), and bank angler surveys were primarily incomplete trips (40 of 54). Walleyes caught during our survey period rarely exceeded $381 \mathrm{~mm}$ (15 inches), and most $(74.5 \%)$ were harvested. Catch rates, harvest rates, and estimates of effort and catch for walleyes were highest during December and March. Boat anglers had higher catch rates and harvest rates than those of bank anglers during all months, except March. A large percentage of anglers indicated that $356 \mathrm{~mm}$ to $381 \mathrm{~mm}$ (14 to 15 inches) walleye were "keepable." Anglers considered trophy walleyes to be 457.2-889 mm (18-35 inches). Angler satisfaction of fishing trips ranged from low $($ rank $=1)$ to high $($ rank $=9)$, with the highest amount of anglers reporting a rank of 1 (35 boat anglers, 17 bank anglers) and a rank of 3 (15 boat anglers, 9 boat anglers). Although anglers harvested a high percentage of the walleye catch, catch and harvest rates for most months were low relative to those reported from other walleye fisheries. Angler dissatisfaction at Summersville Reservoir is likely associated with the slow growth rates, small size structure, and lack of "trophy-sized" fish. Future research on walleye diets, food availability, and walleye movements (daily and seasonal) would be useful toward answering questions about the slow growth rates and the small-size structure of walleyes within Summersville Reservoir.
\end{abstract}




\section{Acknowledgements}

I would like to thank my long time mentor and advisor Dr. Stuart Welsh, the WVU Division of Forestry and Natural Resources, and everyone in the WVU/USGS Cooperative Fish and Wildlife Research Unit. I would also like to thank Dr. George Merovich and David Wellman for serving on my committee, and for their suggestions and guidance along the way. Additionally, I would like to thank the West Virginia Division of Natural Resources for funding my project, and providing me with the opportunity to have such a great project. Thanks also to the WVU Department of Biology for providing me with a teaching assistantship.

I would also like to give special thanks to Brandon Keplinger, Chris McMillion, Chris Zetlin, Ryan and Missy Braham, and my Mom and Dad for their support and encouragement. Lastly, I would like to extend a great deal of thanks to my girlfriend, Amanda White, for supporting me throughout the entire effort, and constantly having faith in me. 


\section{Table of Contents}

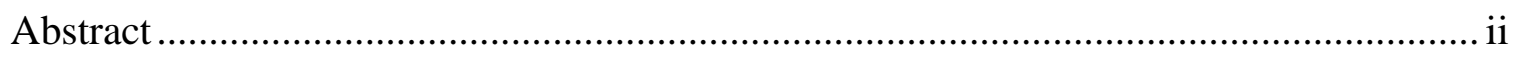

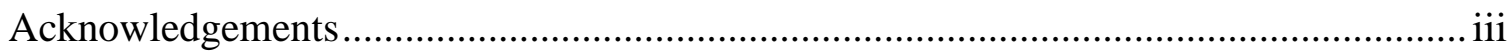

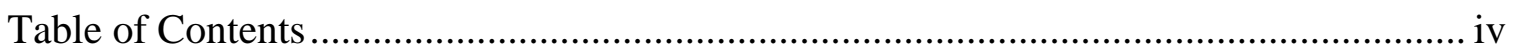

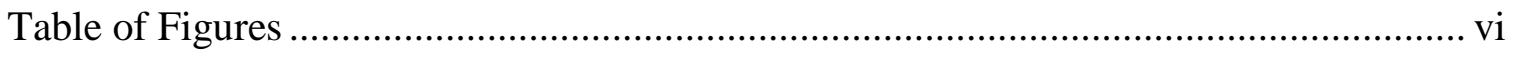

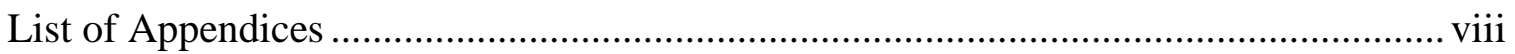

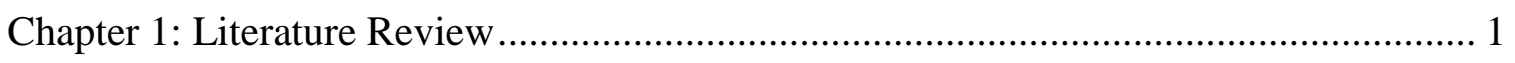

Contents of the thesis .......................................................................................... 1

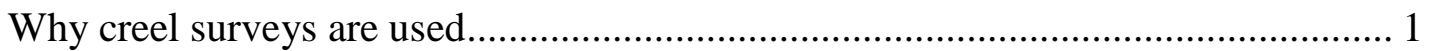

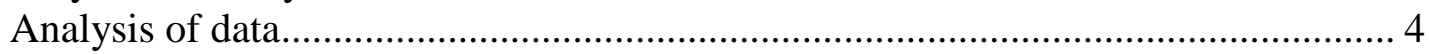

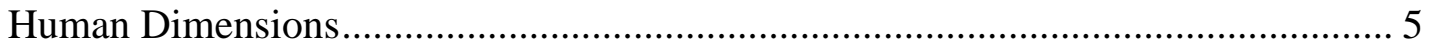

Limitations with creel surveys: Ratio of means vs. means of ratios............................ 6

Target species.................................................................................................. 8

Walleye Management: Catch, Harvest, and Effort ………………………………... 9

Study area: Summersville Lake ......................................................................... 10

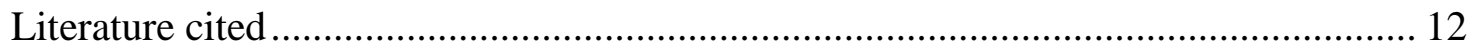

Chapter 2: An angler and creel survey of the walleye (Sander vitreus) fishery at Summersville Reservoir, West Virginia ......................................................................... 16

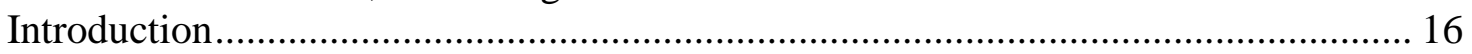

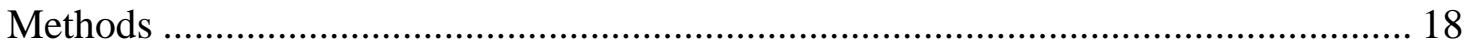

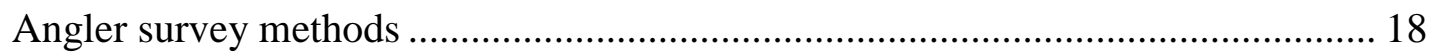

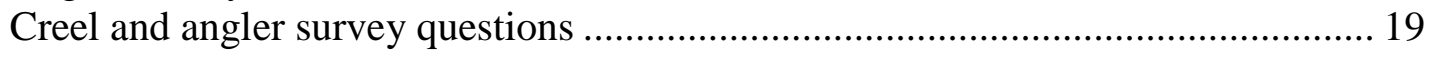

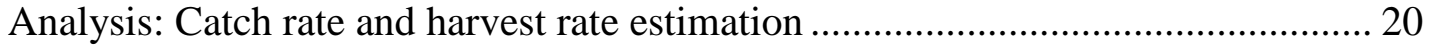

Direct expansion of effort and catch from boat and bank angler data .................... 20

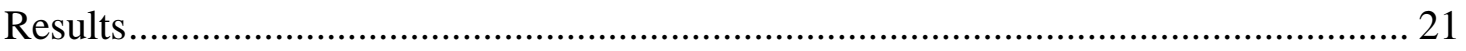

Catch rates, harvest rates, and harvest lengths...................................................... 22

Total fishing effort and total catch from boat and bank angler data ......................... 23

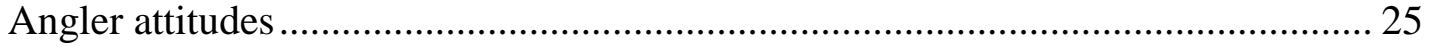

Angler-reported information from previous fishing trips ....................................... 26

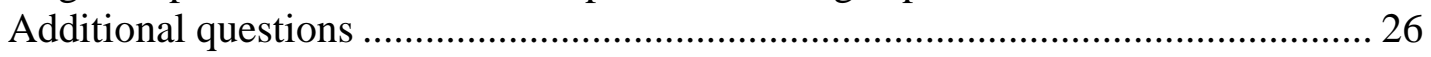

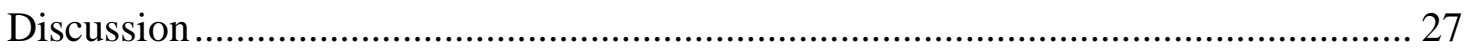




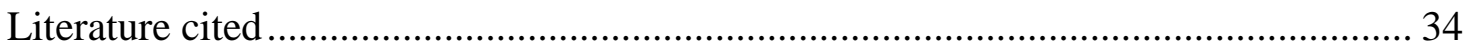




\section{List of Figures}

Figure 1. Summersville Reservoir and the locations of access roads and boat ramps. .... 37

Figure 2. Geographic distribution of angler residences (zip codes). Zip codes of four nonresident anglers were not plotted (Belpre, OH; Elyria, OH; Humble, TX; and Manor,

TX).

Figure 3. Number of walleyes caught and harvested by month at Summersville Reservoir based on creel and angler surveys. Surveys were not conducted for November and August; no walleyes were reported during September surveys.

Figure 4. Length frequency of walleyes caught by boat and bank anglers based on fish measured during the creel survey.

Figure 5. Lengths considered by anglers to be "keepable" walleyes.

Figure 6. Lengths considered by anglers to be "trophy" walleyes.

Figure 7. Angler responses to (A) changes in the overall walleye fishery during the last five years, and (B) changes to the size of walleyes during the last five years.

Figure 8. Angler opinions on changes to the walleye fishing regulations, such as (A) size

limits, (B) bag limits, and (C) size and bag limits. 42

Figure 9. Rank of angler satisfaction of the fishing trip (on the day of interview), where a

rank of 1 means extremely dissatisfied and a rank of 9 means extremely satisfied. 43

Figure 10. Percent of walleye harvested from all walleye caught. 43

Figure 11. Percent of all walleye caught greater than 15 inches. 44

Figure 12. Percent of walleye kept from walleye caught greater than 15 inches. 44 


\section{List of Tables}

Table 1. Residences of surveyed anglers and the estimated time (min) and distance (km) of travel to Summersville, WV.

Table 2. Percent of anglers that targeted four fisheries (walleye, black bass, crappie, and sunfish) or did not target a specific fishery (Any species) within Summersville Reservoir.

Table 3. Frequency of any species, black bass, and walleye fisheries targeted by month (November 2008-October 2009).The November period represents two survey days. There were no surveys during the month of August.

Table 4. Monthly catch rates and harvest rates of anglers targeting walleye estimated from boat (complete trips) and bank (incomplete trips) angler survey data at Summersville Reservoir, WV. Number of interviews followed by standard error are given in parentheses. An asterisk (*) indicates that no anglers were encountered during the survey period.

Table 5. Monthly catch rates and harvest rates for all anglers estimated from boat (complete trips) and bank (incomplete trips) angler survey data from Summersville Reservoir, WV. Number of interviews followed by standard error are given in parentheses. An asterisk (*) indicates that no anglers were encountered during the survey period.

Table 6. Total fishing effort and total catch for boat anglers estimated with angler survey data from Summersville Reservoir, WV. Standard errors are given in parentheses. An asterisk $(*)$ indicates that no anglers were encountered during the survey period.

Table 7. Total fishing effort and total catch for bank anglers estimated with angler survey data from Summersville Reservoir, WV. Standard errors are given in parentheses. An asterisk $(*)$ indicates that no anglers were encountered during the survey period.

Table 8. Total fishing effort and total catch for all anglers (boat and bank anglers combined) estimated with angler survey data from Summersville Reservoir, WV. Standard errors are given in parentheses. An asterisk (*) indicates that no anglers were encountered during the survey period.

Table 9. Comparison of walleye catch and harvest rates for all anglers (boat anglers, bank anglers, weekday and weekend combined) for two West Virginia reservoirs. An asterisk

(*) indicates no available information..

Table 10. Expanded effort (hours) estimated from the number of parked vehicles (which also included an unknown proportion of vehicles associated with non-angling activities). The months of August and November were not sampled. 


\section{List of Appendices}

Appendix A. Core and additional questions of the angler and creel survey at Summersville Reservoir.

Appendix B. Data collected prior to each angler survey at Summersville Reservoir....... 57

Appendix C. Daily weather and water conditions for angler surveys on Summersville

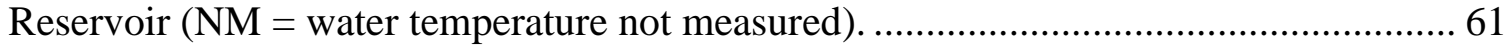

Appendix D. Counts of vehicles (VC) and bank anglers (BA) from angler surveys at

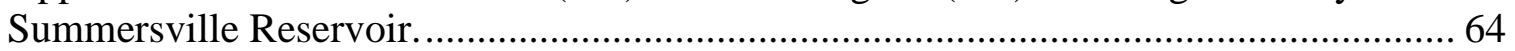




\section{Chapter 1: Literature Review}

\section{Contents of the thesis}

This thesis includes a review of the literature on creel and angler surveys (Chapter 1) and a manuscript from an angler and creel study of the walleye fishery of Summersville Lake, WV (Chapter 2). Chapter 1 reviews angler and creel surveys, analysis methods, human dimensions information, and limitations of creel surveys. Chapter 1 also summarizes the species of interest (walleye) and the study area (Summersville Lake) for the angler and creel study of Chapter 2. The manuscript of Chapter 2 reports catch and harvest rates of walleyes, total effort of anglers and total catch of walleyes, and angler attitudes associated with the walleye fishery at Summersville Lake, WV. Why creel surveys are used

Data from creel and angler surveys are useful for evaluating fisheries and fishery regulations, and aiding fishery management decisions (Matlock 1991). Creel surveys provide estimates related to catch and harvest, such as angling success, the proportion of fish released alive or harvested, and mean length at harvest (Baccante and Colby 1991). Additionally, angler surveys include information on human dimensions, such as angler demographics, opinions, and expectations (Pollock et al. 1994, Malvestuto 1996).

Angler and creel survey data aid fisheries professionals with management decisions for specific fisheries and specific bodies of water. Surveys provide catch and harvest data for specific angler groups, such as boat anglers versus bank anglers, or anglers targeting single species versus those targeting multiple species. Data from angler and creel surveys on diverse groups of anglers, as well as the differential effort, catch 
rates, and harvest rates of angler groups, provide important information for managing a fishery (Pollock et al. 1994). One must have knowledge of available resources in order to correctly manage and utilize the resources (Rawson 1957, Matlock 1991). Creel surveys measure resource use through public interactions, and allow a variety of fishery parameters to be estimated, including catch rates, harvest rates, total effort, and total catch.

How creel surveys are used

Different methods are used for angler and creel surveys depending on available funding, personnel, and research questions. The size of the study area also influences the study design of an angler or creel survey. Methods include both passive and active techniques to obtain angler and creel survey information. Study designs and methods can be simple or complex. For example, mail surveys involve sending sampling forms to angler's residences, and do not require extensive sampling efforts. Access point surveys are more labor-intensive where creel clerks intercept anglers during or after fishing trips (Pollock et al. 1994).

When sampling the recreational creel, one must consider size and access of the study area. For example, if there is only one site, then the clerk would likely choose a single-access design. However, if a study area has multiple sites then one may choose to use a roving creel survey or a multiple access point method, where the clerk conducts interviews at multiple sites. Most methods allow for estimation of catch and harvest rates, total catch, and total effort, but it is important to select a method relevant to the sampling area (Pollock et al. 1994). For the Summersville Lake study (Chapter 2), I used a roving design for bank angler interviews, and a multiple access point design to interview boat 
anglers at boat ramps. Bank angler interviews primarily represented incomplete trips, and boat angler interviews were predominantly completed trips. This was because I interviewed bank anglers while they were actually fishing and boat anglers as they were coming off of the water from a day of fishing.

Randomized survey designs are used to reduce bias in estimates of catch rates, harvest rates, total effort, and total catch (Pollock et al. 1994). Also, Malvestuto et al. (1978) discussed the importance of non-uniform probability sampling. Specifically, sampling units are often stratified into days, months, or years. Deroba et al. (2007) suggested that studies should be stratified seasonally to account for temporal variability. Angler and creel surveys are often stratified by weekends and weekdays because angler effort is often higher on weekends (Austen et al. 2007, Deroba 2007).

With roving creel surveys, the creel clerk moves from site to site during one or more sampling periods within a sampling day. Sampling periods within a single day are often randomized. The number of interviews often differs among morning, midday, and evening time periods. One study found that most interviews were taken in the latter part of the day (Deroba et al. 2007). Studies that use random sampling throughout the entire day reduce biases associated with time of day (Malvestuto et al. 1978, Hayne 1991, Beard et al. 1997).

As mentioned previously, angler and creel surveys are used to estimate total catch, total harvest, catch and harvest rates, and total effort for a sample area. Total catch is the number of fish caught in the sample area over a particular period of time. Harvest is the total number of individuals kept or harvested over a particular amount of time. Catch 
and harvest rates are often estimated as means of the total number of fish (caught or harvested) divided by effort (the total number of hours fished; Pollock et al. 1994).

It is important to consider how information on groups of anglers is recorded, as a fishing party or individually. If the information is obtained for a group, then one must multiply the effort hours by the number of individuals present (Vandevalk et al. 2007). This allows the clerk to obtain estimates of the catch, harvest, and effort of the particular group without singling out individuals for interviews. Also, this can provide more time for interviews of other parties.

Analysis of data

Two of the most commonly used methods for analysis of creel survey data are the ratio of means method, and the means of ratio method. The ratio of means method is used to find the actual amount of catch for each day in the sample, and is often used for completed trip data. The catch rate is calculated by dividing the total daily catch by the total daily effort of all anglers. The means of ratios method estimates the average angler catch, and is used for incomplete fishing trips. Therefore, the selection of which method depends on the type of sampling used (incomplete versus complete trips). Access point surveys work well with the ratio of means method because data often represent completed fishing trips. Roving surveys work well with means of ratio method because the creel clerk is interviewing anglers during a fishing trip (which represents incomplete fishing trip data; Hayne 1991, Pollock et al. 1994, Jones et al. 1995, Rasmussen et al. 1998).

The choice of estimator is also based on the objectives of the study. Jones et al. (1995) found that when the objective is to produce a measure of angler satisfaction, it is 
best to use the means of ratio method. However, when total catch is the target they found it depends on whether or not the fishery can be sampled with equal probability. Both estimates were found to have had decreased bias when over 100 anglers were interviewed, so a large sample size will produce better estimates (Jones et al. 1995, Austen et al. 2007). The ratio of means estimator has been found to have less bias than the other method, especially in the case that the means of ratio estimators have several trips with short durations. These shorter trip lengths can cause variances to be unstable (Lockwood 2004, Keefe et al. 2009).

\section{Human Dimensions}

The field of human dimensions is described as the science of using the thoughts and attitudes of the general public in making wildlife and fisheries management decisions (Wilde et al. 1996, Manfredo et al. 1998). In a general sense, human dimension data focus on the angler instead of the fish. For example, angler demographics provide information on angler residences, and on the proportion of in-state versus out-of-state anglers using a fishery (Churchill et al. 2002). Angler survey questions that address opinions on regulation changes, such as size limits and bag limits, are useful to fishery management decision-making processes (Matlock 1991). Also, data from survey questions on angler expectations, such as sizes of "keepable" and "trophy" fish are useful toward regulation changes. Human dimensions data gathered from surveys can be as important to fisheries management as biological data in some instances (Wilde et al. 1996). These data can allow decision makers to make choices that more strongly support their constituency's thoughts and opinions, and by combining this information with 
biological data one can provide a much more satisfied community of anglers (Wilde et al. 1996, Churchill et al. 2002).

Angler attitudes are important aspects of human dimensions data, such as attitudes about changing regulations, trophy sizes, stocking, or harvestable fish sizes (Churchill et al. 2002, Simson 2008). Wilde et al. (1996) found that most fisheries agencies (>50\%) thought that support of regulations, angler attitudes and opinions, satisfaction, and economic information ranked among the highest importance as human dimensions information.

\section{Limitations with creel surveys: Ratio of means vs. means of ratios}

Numerous studies have been conducted to examine the relationship between ratio of means and means of ratios estimators (Fierstine et al. 1978, Lockwood et al. 1999, Lockwood 2004, Keefe et al. 2009). Some have expressed concern about the potential for bias associated with the means of ratios equation, because catch rate and total catch are based on incomplete trips, essentially extrapolating an amount based upon what the angler has caught previously. This equation also is based upon the assumption that the amount of fish caught per hour does not change. If the number of fish caught increases or decreases after the initial interview, then the equation can provide biased estimates (Pollock et al. 1994, Lockwood 2004, Keefe et al. 2009).

There are many assumptions associated with angler and creel surveys. An important assumption is that anglers accurately recall their catch totals. Catch and harvest rates are based upon angler recollection. Anglers often over or underestimate catch, harvest, and effort (Malvestuto et al. 1978, Mallison and Cichra 2004). Therefore, this must be taken into consideration when interviewing anglers. Lengths of fishing trips must 
be correctly determined, and clerks must measure this in a consistent manner. Rates can be skewed because of angler experience, and fishing trips are assumed to have uniform catch and harvest rates during the trip. If assumptions are violated, then estimates are likely to be biased.

Another factor to consider with both incomplete and complete fishing trips is the length of the fishing trip at the time of the interview. Phippen and Bergsen (1987) debated that fishing time could either be considered from the time the angler left the car, or could be measured as the amount of time that fishing lines are in the water. One must consider such factors, while also acknowledging that the estimate is based from the angler's memory and could be exaggerated (Malvestuto et al. 1978).

Both catch and harvest rates can be biased because of differential angling abilities. Experienced anglers often catch more fish (Baccante et al. 1995, Jones et al. 1995). VanDeValk et al. (2007) found that larger party sizes often reduce estimates of catch rates. Also, some angler groups practice catch and release fishing, whereas others do not (Ker 2007). If study objectives are focused on the total angling population, but data are based on a specific group, then harvest rates could be over or underestimated. Angler catch and harvest rates do not always reflect population density as expected. For instance, VanDeValk et al. (2005) found that angler catch rates for walleye are not always related to population abundance, and that catch rates can vary based upon the competition for available resources. They found that when prey abundance declined, then walleyes became more susceptible to angling. Also, anglers caught a greater amount of fish during periods of lower walleye abundance. However, Beard et al. (1997) suggested that walleye catch rates are proportional to walleye density. This relationship 
was also supported by Serns and Kempinger (1981), who also found that older walleyes were less vulnerable to angling.

All of the aforementioned variables must be taken into consideration in order to conduct a successful creel survey. Catch rate estimators can vary on the amount of bias associated with them. Angler recollection can play an important role on how viable the information is. The length of the time the angler spends fishing the area can affect catch rates as well. The abilities and techniques used by anglers can produce varying results, and have the potential to create bias in both directions. Also, when managing the resource, agencies must take into consideration the fact that not all catch rates reflect population abundances. Careful examination of these variables will produce less bias. Target species

For the study at Summersville Lake, the species of interest was the walleye (Sander vitreus), which are a highly sought after sport fish in many regions (Johnson et al. 1988, Mion et al. 1998). Walleyes support economical benefit through both sport and commercial fisheries (Rose et al. 1999). Walleye harvest rates are often high, because of their status as an excellent table fish (Palmer et al. 2005). Walleyes are affected by water clarity, temperature, habitat structure, and overall quality issues including $\mathrm{pH}$ (Lester et al. 2004). They prefer and proliferate in areas of good water quality, productive systems with low water clarity, and areas with good structure to provide baitfish habitat. Walleyes act as a terminal predator, and through predation have the ability to affect the population abundance and structure of many different prey species (Rose et al. 1999). Walleyes occur in both lotic and lentic systems, and are stocked in many areas. The native distribution of walleye is generally limited to the natural lakes and rivers of 
Canada and the northern United States (Carlander1997, Zipfel 2006). However, reproducing populations exist in many rivers and lakes throughout the Mississippi drainage, and across the eastern and western United States (Mion et al. 1998, Ickes et al. 1999, Rose et al. 1999). Some bodies of water do not support walleye reproduction, and are stocked annually by agencies in order to please the public (Johnson et al. 1988).

\section{Walleye Management: Catch, Harvest, and Effort}

Estimates of catch rates of walleyes based on angler and creel surveys differ among regions and water bodies, including values of $0.04-0.56$ walleye/hr for Island Lake Reservoir, MN (Frohnaue 2008), 0.04-0.47 walleyes/hr for Oneida Lake, NY (VanDeValk et al. 2005), and 0.20 walleye/hr in Northern Wisconsin (Beard et al. 1997). Harvest rate estimates also differ, with estimates reported as 0.03 walleyes/hr in Northern Wisconsin (Deroba et al. 2007), 0.65 walleyes/hr in Wisconsin (Staggs et al. 1990), and 0.84 walleyes/hr (Frohnaue 2008). Catch and harvest rates are affected by time of year, angling pressure, size and age structure, and angler specialization.

Catch and harvest of walleyes vary temporally, and tend to increase when water temperatures are cool. Walleyes move more frequently during cooler water periods, and may move from the pelagic areas to inland banks in an attempt to find prey, which increases their susceptibility to anglers. Catch rates often increase during the spawning period when fish congregate in smaller areas, and are more susceptible to angling (Olson 1958). Also, catch rates of walleyes often increase during their preferred foraging periods of early morning, late evening, and night (Lester et al. 2004).

Walleye catch and harvest differ during warm months due to increases in the amount of total anglers using the fishery. Many anglers do not have the ability or 
equipment to successfully target walleye. Specialized groups of anglers, such as anglers that target walleyes, have the greatest angling success (Baccante 1995). Therefore, when there is an increase in unspecialized anglers it can cause catch and harvest rates to be biased based upon dilution of the catch rates (Baccante 1995, Jones et al. 1995). Study area: Summersville Lake

Summersville Reservoir, located one mile south of Summersville, WV, is a 1052 hectare (2600 acre) impoundment on the Gauley River in south-central West Virginia and supports an established recreational walleye (Sander vitreus) fishery. The reservoir, impounded in 1966 for flood control, undergoes a draw-down period that begins each year during fall. During draw-down, reservoir elevation is lowered from 1652 to $1575 \mathrm{ft}$ during mid September, and remains at low levels during winter. With increased rainfall and higher river discharges during spring, the lake is elevated during April (United States Army Corps of Engineers 2009). The reservoir has five boat ramps: the "Winter Ramp" near the dam, Salmon Run boat ramp, Long Point boat ramp, and two ramps at Battle Run. During draw-down, the Battle Run boats ramps are closed when reservoir elevations are $<1624$ and $1649 \mathrm{ft}$, and the Salmon Run boat ramp is closed at a reservoir elevation $\leq 1639 \mathrm{ft}$. All boat ramps and adjacent areas are open to bank angling and the use of small boats year-round, except the Long Point boat ramp where the marina restricts bank fishing access.

Walleyes are targeted by boat and bank anglers during all months, but effort increases during the draw down period from fall through spring (Shingleton 1992, 1993). The reservoir also provides year-round fishing opportunities for several other game 
fishes, including channel catfish (Ictalurus punctatus), rockbass (Ambloplites rupestris), smallmouth bass (Micropterus dolomieu), spotted bass (M. punctulatus), largemouth bass (M. salmoides), black crappie (Pomoxis nigromaculatus), white crappie (P. annularis), and bluegill (Lepomis macrochirus).

Summary

This first thesis chapter provided a review of angler and creel surveys, analysis methods, human dimensions information, and limitations of creel surveys. Also, this chapter summarized the species of interest (walleye) and the study area (Summersville Lake) for the angler and creel study of Chapter 2. The following manuscript (Chapter 2) reports catch and harvest rates of walleyes, total effort of anglers and total catch of walleyes, and angler attitudes associated with the walleye fishery at Summersville Lake, WV. 


\section{Literature cited}

Austen, D., W. Brofka, J. Marsden, J. Francis, J. Palla, J. Bence, R. Lockwood, J. Rakoczy, K. Smith and B. Eggol. 2007. Lake Michigan creel survey methods. University of Illinois at Urbana-Champaign Library Large-scale Digitization Project.

Baccante, D.A., and P.J. Colby. 1991. Quantifying walleye angling success. American Fisheries Symposium 12: 397-405.

Baccante, D. 1995. Assessing catch inequality in walleye angling fisheries. North American Journal of Fisheries Management 15: 661-665.

Beard, T.D., Jr., S.W. Hewett, Q. Yang, R.M. King, and S.J. Gilbert. 1997. Prediction of angler catch rates based on walleye population density. North American Journal of Fisheries Management 17: 621-627.

Carlander, K. D. 1997. Handbook of Freshwater Fishery Biology, Vol. III.

Churchill, T., P. Bettoli, D. Peterson, W. Reeves, and B. Hodge. 2002. Angler conflicts in fisheries management: A case study of the striped bass controversy at Norris Reservoir, Tennessee. Fisheries Management Feature 27: 10-19.

Deroba J., M. Hansen, N. Nate, and J. Hennessy. 2007. Temporal profiles of walleye angling effort, harvest rate, and harvest in Northern Wisconsin lakes. North American Journal of Fisheries Management 27: 717-727.

Fierstine, H., J. Geis, and S. Gustafson. 1978. A statistical comparison of incomplete and complete angler trip catch rates. Minnesota Department of Natural Resources Division of Fish and Wildlife Section of Ecological Services Investigational Report 360.

Frohnaue, N. 2008. Completion report: Estimating creel statistics and walleye exploitation on Island Lake Reservoir, Minnesota using a stratified random, roving creel survey and walleye tagging. Minnesota Department of Natural Resources Section of Fisheries

Hayne, D.W. 1991. The access point creel survey: procedures and comparison with the roving-clerk survey. Pgs. 123-138 in D. Guthrie, J.M. Hoenig, M. Holliday, C.M. Jones, M.J. Mills, S.A. Moberly, K.H. Pollock, and D. R. Talhelm, editors. Creel and Angler Surveys in Fisheries Management. American Fisheries Society, Symposium 12, Bethesda, Maryland.

Ickes, B., A. Stevens, and D. Pereira. 1999. Seasonal distribution, habitat use, and spawning locations of walleye (Stizostedion vitreum) and sauger (S. canadensis) in pool 4 of the Upper Mississippi River, with special emphasis on winter 
distribution related to a thermally altered environment. Minnesota Department of Natural Resources Investigational Report, 481.

Johnson, B., D. Smith, and R. Carline. 1988. Habitat preferences, survival, growth, foods, and harvest of walleyes and walleye X sauger hybrids. North American Journal of Fisheries Management 8: 292-304.

Jones C., D. S. Robson, H. Lakkis, and J. Kressel. 1995. Properties of catch rates used in analysis of angler surveys. Transactions of the American Fisheries Society 124: 911-928.

Keefe, D., R. Perry, and J. Luther. 2009. A comparison of two methodologies for estimating brook trout catch and harvest rates using incomplete and complete fishing trips. North American Journal of Fisheries Management 29: 1058-1064.

Ker, S. J. 2007. Characteristics of Ontario muskellunge (Esox masquinongy) fisheries based on volunteer angler diary information. Environmental Biology of Fishes 79: 61-69.

Lester, N., A. Dextrase, R. Kushneriuk, M. Rawson, and P. Ryan. 2004. Light and temperature: key factors affecting walleye abundance and proportion. Transactions of the American Fisheries Society. 133: 588-605.

Lockwood, R., D. Benjamin, and J. Bence. 1999. Estimating angling effort and catch from Michigan roving and access site angler survey data. Michigan Department of Natural Resources Fisheries Research Report 2044.

Lockwood, R. 2004. Comparison of access and roving catch rate estimates under varying within-trip catch-rates and different roving minimum trip lengths. Michigan Department of Natural Resources Fisheries Research Report 2069.

Mallison, C and C. Cichra. 2004. Accuracy of angler-reported harvest in roving creel surveys. North American Journal of Fisheries Management 24: 880-889.

Manfredo, M., D. Decker, and M. Duda. 1998. What is the future for human dimensions of wildlife? Transactions of the $63^{\text {rd }}$ North American Wildlife and Natural Resources Conference 278-292.

Malvestuto, S, W. Davies, and W. Shelton. 1978. An evaluation of the roving creel survey with nonuniform probability sampling. Transactions of the American Fisheries Society 107: 255-262.

Malvestuto, S. 1996. Sampling the recreational creel. Pgs. 591-623 in B. R. Murphy and D. W. Willis, editors. Fisheries Techniques, second edition, American Fisheries Society, Bethesda, Maryland. 
Matlock, G. C. 1991. Use of surveys in decision making. Pgs. 1-4 in D. Guthrie, J. M. Hoenig, M. Holliday, C.M. Jones, M. J. Mills, S. A. Moberly, K. H. Pollock, and D. R. Talhelm, editors. Creel and Angler Surveys in Fisheries Management. American Fisheries Society, Symposium 12, Bethesda, Maryland.

Mion, J., R. Stein, E. Marschall. 1998. River discharge drives survival of larval walleye. Ecological Applications 8: 88-103.

Olson, D. 1958. Statistics of a walleye sport fishery in a Minnesota Lake. Transactions of the American Fisheries Society 87: 52-72.

Palmer, G., B. Murphy, and E. Hallerman. 2005. Movements of walleyes in Claytor Lake and the Upper New River, Virginia, indicate distinct lake and river populations. North American Journal of Fisheries Management 25: 1448-1455.

Phippen K. and E. Bergersen. 1987. Angling definitions and their effects on the accuracy of count-interview creel survey harvest estimates. North American Journal of Fisheries Management 7: 488-492.

Pollock, K.H., C.M. Jones, and T.L. Brown. 1994. Angler survey methods and their applications in fisheries management. American Fisheries Society, Special Publication 25, Bethesda, Maryland.

Rasmussen P., M. Staggs, T. Beard, and S. Newman. 1998. Bias and confidence interval coverage of creel survey estimators evaluated by simulation. Transactions of the American Fisheries Society 127: 469-480.

Rawson, D.S. 1957. The life history and ecology of the yellow walleye, Stizostedion vitreum, in Lac la Ronge, Sascatchewan. Transactions of the American Fisheries Society 86 : 15-37.

Rose K., E. Rutherford, D. McDermot, J. Forney, and E. Mills. 1999. Individual-based model of yellow perch and walleye populations in Oneida Lake. Ecological Monographs 69: 127-154.

Serns, S. and J. Kempinger. 1981. Relationship of angler exploitation to the size, age, and sex of walleyes in Escanaba Lake, Wisconsin. Transactions of the American Fisheries Society 110: 216-220.

Shingleton, M.V. 1992. Reservoir investigations, Summersville Lake study for period of January 1, 1991 - December 31, 1991. West Virginia Department of Natural Resources, D-J Report, Project F-11-R-30.

Shingleton, M.V. 1993. Reservoir investigations, Summersville Lake study for period of January 1, 1992 - December 31, 1992. West Virginia Department of Natural Resources, D-J Report, Project F-11-R-31. 
Simonson, T. 2008. Muskellunge Management Update. Wisconsin Department of Natural Resources: Bureau of Fisheries Management

Staggs, M., R. Moody, M. Hansen, and M. Hoff. 1990. Spearing and sport angling for walleye in Wisconsin's ceded territory. Wisconsin Department of Natural Resources, Administrative Report 31.

VanDeValk, A., J. Jackson, S. Krueger, T. Brooking, and L. Rudstam. 2007. Influence of party size on trip length on angler catch rates on Oneida Lake, NY. North American Journal of Fisheries Management 27: 127-136.

VanDeValk, A., J. Forney, J. Jackson, L. Rudstam, T. Brooking, and S. Krueger. 2005. Angler catch rates and catchability of walleyes in Oneida Lake, New York. North American Journal of Fisheries Management 25: 1441-1447.

Wilde, G.R., Ditton, R.B., Grimes S.R., and R.K. Riechers. 1996. Status of human dimensions surveys sponsored by state and provincial fisheries management agencies in North America. North American Journal of Fisheries Management 21: 12-17.

Zipfel, K. 2006. The distribution and status of native walleye (Sander vitreus) in West Virginia. Master of Science thesis Submitted to the College of Art and Sciences of Ohio University. 


\section{Chapter 2: An angler and creel survey of the walleye (Sander vitreus) fishery at Summersville Reservoir, West Virginia}

\section{Introduction}

Summersville Reservoir, a 1052 hectare (2600 acre) flood-control impoundment on Gauley River in south-central West Virginia, provides a year-round recreational walleye fishery for boat and bank anglers. An annual water level draw-down occurs during fall for flood-control, which influences angler access and walleye catch rates within the reservoir. The West Virginia Division of Natural Resources (WVDNR) manages the walleye fishery of Summersville Reservoir and sets regulations, based in part, on fishery dependent and fishery independent data. Current estimates of catch rates, harvest rates, total fishing effort, and total catch are needed to aid management decisions on the walleye fishery in Summersville Reservoir and these data are obtainable from creel and angler surveys (Pollock et al. 1994). Also, survey data on attitudes and demographics of anglers are desirable for making informed management decisions regarding the walleye fishery at Summersville Reservoir.

Angler access at Summersville Reservoir is influenced by annual water level draw-down and availability of boat ramps. Reservoir elevation is lowered from $503.5 \mathrm{~m}$ (1652 feet) to $480.1 \mathrm{~m}$ (1575 ft) during September, remains at low levels during winter (but fluctuates with rain events), and is elevated to pre draw-down levels during April. The reservoir has four boat ramps (Salmon Run, Long Point, Battle Run, and the "Winter Ramp" near the dam, Figure 1). During water level draw-down, the Battle Run boat ramp is dewatered at reservoir elevations below 495 m (1624 ft), and the Salmon Run boat ramp is closed at a reservoir elevation below $499.6 \mathrm{~m}$ (1639 ft). All boat ramps and 
adjacent areas are open to bank angling and the use of small boats year-round, except the Long Point boat ramp where the marina restricts bank fishing access.

During the early 1980s and early 1990s, the WVDNR found that anglers harvested a high percentage of their catch, but estimated relatively low catch rates of walleye in Summersville Reservoir (Ramsey and Pierce 1981; Shingleton 1992, 1993). A creel survey in 1980 estimated a catch of 476 walleyes (412 fish or $87 \%$ harvested) during a three month period, April - June (Ramsey and Pierce 1981). Five additional creel surveys during April 1990 - October 1990, November 1990 - March 1991, April 1991 - October 1991, November 1991 - March 1992, and April - October 1992 estimated catches of 359 (66\% harvested), 241 (77\% harvested), 643 (81\% harvested), 841 (62\% harvested), and 593 (87\% harvested), respectively (Shingleton 1992, 1993). Based on these surveys, catch rates of walleyes in Summersville Reservoir by all anglers (estimated as total catch divided by total effort) ranged from 0.008 to 0.148 fish per hour (Ramsey and Pierce 1981; Shingleton 1992, 1993). Also, the ratio of walleyes harvested to total effort ranged from 0.006 to 0.092 fish per hour (Ramsey and Pierce 1981; Shingleton 1992, 1993). These estimates, however, are based on the combined effort (hours) of walleye anglers and anglers targeting other species. Separate estimates of catch rates and harvest rates are needed for bank anglers versus boat anglers, and walleye anglers versus all anglers.

Studies have also reported slow growth rates of walleyes within Summersville Reservoir. Wellman (2011) reported a narrow range of mean lengths from age 2 (378 mm, 14.9 inches) to age 10 (393 mm, 15.5 inches; Figure 2). Estimates of average lengths for age 3 and age 4 walleyes in 1991 were $414 \mathrm{~mm}$ (16.3 inches) and $450 \mathrm{~mm}$ (17.7 
inches), and those for 1992 were $422 \mathrm{~mm}$ (16.6 inches) and $460 \mathrm{~mm}$ (18.1 inches)

(Shingleton 1992, 1993). These estimates of age 3 and age 4 individuals are higher than those reported by Wellman (2011), but individuals older than age 4 were not reported by Shingleton $(1992,1993)$. Slow growth rates not only shape the age/length distribution of a walleye population, but also impact total catch, catch rates, and angler attitudes.

The goal of my study was to evaluate the walleye fishery at Summersville Reservoir using data from creel and angler surveys. My specific objectives were to (1) estimate catch and harvest rates of walleyes using catch and effort data, and (2) assess angler attitudes on current and previous fishing trip satisfaction, the quality of the fishery, bag limit and size limit changes, and the size of "keepable" and "trophy" fish. Current catch information and angler attitudes are important for management of the fishery, especially given previous estimates of high harvest proportions and low growth rates of walleyes.

\section{Methods}

\section{Angler survey methods}

I conducted creel and angler surveys of boat and bank anglers at Summersville Reservoir from 28 November 2008 through 31 October 2009. Boat angler surveys followed a point access design, and bank angler surveys followed a roving design (Pollock et al. 1994). In addition to angler surveys, I recorded the number of vehicles in parking areas and the number of bank anglers during each site visit. All months except August and November were represented in the survey period. Angler surveys were randomly selected for two 10-hour sample days per week (stratified for 1 weekend and 1 week day). The study design included site visits to all open boat ramps during each 
survey day, but closures left only two or three boat ramps open during most of the study period. Each 10-hour sample day was partitioned into three rounds of visits to three or four access sites, where site visits within each round were randomized. The duration of each site visit ranged from 40 to 60 minutes.

Creel and angler survey questions

During each interview, I recorded angler type (boat or bank angler), trip status (incomplete or complete trip), and number of anglers in the fishing party. I also asked for permission to count and measure walleyes (total length, mm) from angler creels, and asked questions to determine the following: angler residence (zipcodes, to estimate mean travel distance and mean travel time), start time of fishing trip (to estimate hours of fishing effort), species of fish targeted, and numbers of fish caught, kept, and released (to estimate catch and harvest; Appendix A).

Angler responses to additional survey questions provided information on the number of days per year anglers fish for walleyes, the percent of walleyes kept on an average fishing trip, the percent of walleyes caught that exceed 15 inches $(381 \mathrm{~mm})$ on an average fishing trip, and the percent of walleyes greater than 15 inches $(381 \mathrm{~mm}) \mathrm{kept}$ on an average fishing trip. I recorded the following information based on angler attitudes: angler satisfaction of the fishing trip (rank scores 1-9 based upon overall trip satisfaction), lengths that anglers would consider as "trophy" and "keepable" walleyes, the quality of the walleye fishery at Summersville Reservoir within the last five years, and opinions about future bag limit and size limit changes for the walleye fishery at Summersville Reservoir. Two questions were unrelated to the walleye fishery at 
Summersville: (1) What warmwater fish species do you fish for most often in West Virginia?; (2) Do you fish other West Virginia waters for walleye?

\section{Analysis: Catch rate and harvest rate estimation}

Using data from boat anglers (primarily completed trips), I estimated catch and harvest rates of walleyes as the ratio of mean catch to mean effort and as the ratio of mean harvest to mean effort (Hoenig et al. 1997, Pollock et al. 1997). For data from bank anglers (primarily incomplete trips), I used the mean of ratios estimator (Hoenig et al. 1997, Pollock et al. 1997) to estimate catch and harvest rates of walleyes.

\section{Direct expansion of effort and catch from boat and bank angler data}

For boat anglers, direct expansion of effort and catch for each sample month followed the methods of Pollock et al. (1994) for multiple access sites and two strata (weekday and weekend). I used mean values of daily fishing effort and daily catch for weekday and weekend strata to estimate total fishing effort and total catch. I estimated total fishing catch and effort separately for weekday and weekend strata by multiplying the catch rate or mean daily effort by the total week or weekend days within the month. Weekday and weekend estimates were summed to obtain a monthly estimate. I calculated variances for total effort and total catch using equations provided in Pollock et al. (1994). These variances took into account the number of values in a sample, other variances, and the number of days available to sample, each of which varied depending on the weekend, weekday, or catch rate used.

I used counts of bank anglers and the length of time of survey routes for each site visit to estimate daily effort, weekend and weekday total effort, and monthly total effort. I estimated weekend, weekday, and monthly total catch by multiplying the bank angler 
catch rate (from the mean of ratios estimator) by the weekend, weekday, and monthly estimates of total effort, respectively. I calculated variances for total effort and total catch following Pollock et al. (1994).

\section{Direct expansion of effort from vehicle count data}

The time interval count method (vehicle counts) was also used to estimate effort for all anglers following the methods of Pollock et al. (1994). The number of parked vehicles was counted at each access site during each site visit. The number of parked vehicles at all access sites was converted to daily averages of angler party hours and direct expansion was used to estimate total angler party hours for weekdays and weekends. For each month, weekday and weekend estimates were summed to estimate total angler party hours. Total angler hours of effort for each month were estimated by multiplying the estimate of angler party hours by the average number of anglers per party. Vehicle count data does not include information on angler types, so total angler hours could not be partitioned by boat anglers vs. bank anglers, or by walleye anglers vs. all anglers.

\section{Results}

A total of 84 survey days yielded 165 interviews (111 boat anglers, and 54 bank anglers). Boat angler surveys mostly represented completed trips (98 of 111 interviews), and bank angler surveys were primarily incomplete trips (40 of 54; Appendix B). I could not conduct surveys on eight days of ice cover during part of January and February (Appendix C). I also did not conduct surveys within the months of November or August, except data collected on 28 November were included in the analysis for December.

Most interviews were with West Virginia resident anglers (97.6\%; Figure 3). 
Using a GIS-based navigator, I estimated the travel distances $[$ mean $=82.7 \mathrm{~km}(51.3$ miles), $\mathrm{SE}=6.01]$ and travel times (mean $=56.5$ minutes, $\mathrm{SE}=3.69)$ between West Virginia residence zipcodes and Summersville, West Virginia (Table 1). A large proportion of anglers (45.9\%) were within 50 road kilometers (31 miles) of Summersville, WV. Residences within 100 road kilometers (62 miles) of Summersville, WV, represented $65.4 \%$ of anglers. Angler residences from farther distances (> 100 road $\mathrm{km}$ ) were often close to interstate corridors, possibly reflecting driving time or population centers (Figure 3).

Walleye anglers comprised $18.8 \%$ of anglers within the survey (Table 2). The highest numbers of interviews of walleye anglers occurred in March (n=7), and December ( $n=5$; Table 3). Numbers of interviews of all anglers were highest in April $(n=26)$, May $(n=43)$ and June $(n=21)$. The number of walleyes caught and reported was highest during the period from 28 November to December 31(n $=38)$, representing $53.5 \%$ of all walleyes caught. Twenty walleyes were caught and reported on 28 November, and 18 walleyes were caught during interviews within December. I interpret this as evidence that November was also a month with a relatively high walleye catch. March was the only other month with a relatively high walleye catch $(n=17)$. Catch rates, harvest rates, and harvest lengths

Anglers within the survey caught 71 walleyes (55 harvested, 16 released; Figure 4). Boat and bank anglers harvested 76.1\% (38 of 53 walleyes) and 94\% (17 of 18), respectively. Walleye anglers typically had higher catch rates and higher harvest rates of walleyes than those of all anglers (Tables 4 and 5). The December period (which included the last weekend in November) had the highest catch and harvest rates, where 
boat anglers had weekday and weekend catch rates of 0.94 and 1.10 walleyes per hour, respectively (Figure 4, Table 4). Boat angler harvest rates for the December period were 0.58 (weekday) and 0.81 (weekend) walleyes per hour (Table 4). Relatively few bank anglers reported catches of walleyes during the study, except for bank anglers targeting walleyes during March and April. The March estimates of catch and harvest rates for bank anglers were 0.88 walleyes/hr (weekday) and 0.26 walleyes/hr (weekend). In April, a weekend catch rate of 0.62 walleyes/hr was estimated for bank anglers. Lengths were measured or reported by anglers from 60 of 71 walleyes caught; mean= $378.6 \mathrm{~mm}(14.9$ inches), $\mathrm{SE}=4.6$, range 304-455 $\mathrm{mm}$ (11.9-17.9 inches) (Figure 5). The mean length of walleyes harvested by boat anglers mean=378.29 (14.9 inches), $\mathrm{SE}=5.97$, range 330-455 (12.9-17.9 inches), $\mathrm{n}=38$ was similar to that of bank anglers mean= 377.1 (14.8 inches), $\mathrm{SE}=7.0$, range $340-440 \mathrm{~mm}(13.3-17.3$ inches), $\mathrm{n}=17$ (Figure 5).

\section{Total fishing effort and total catch from boat and bank angler data}

Estimates of fishing effort and total catch of boat anglers exceeded those of bank anglers (Tables 6 and 7). For boat anglers targeting walleye, the estimates of fishing effort and catch were highest during the December period, where an estimated 728 hours of effort produced an estimated 624.5 walleyes (Table 6). For all boat anglers (including those targeting walleyes), estimates of fishing effort were highest during December (1152.7 hours) and May (2029.6 hours), but the estimates of walleye catches differed between December (609.8 walleyes) and May (13.5 walleyes; Table 6).

The highest frequency of bank anglers was recorded at Salmon Run (54.0\%) and the lowest was at Long Point Marina (3.2\%), with a remaining distribution of Battle Run (28.6\%), Brock’s Bridge (9.5\%), and Winter Ramp (4.8\%). For bank anglers targeting 
walleyes, estimates of both fishing effort and walleye catches were highest for March (80.8 hours and 62.8 walleyes) and April (13.5 hours and 8.3 walleyes; Table 7). For all bank anglers (including those targeting walleyes), estimates of fishing effort were highest during April (52.8 hours, 11.9 walleyes), May (114.5 hours, 0.0 walleyes), and June (124.5 hours, 0.0 walleyes; Table 7).

Estimates of total effort and total catch of walleyes during 5 months of low water levels (October - March, excluding November) exceeded those for the months of April September (excluding August; Table 8). Estimates of total effort and total catch of anglers targeting walleyes (boat and bank anglers combined) were 908.9 hours and 778.8 walleyes during October - March, and 968.5 hours and 29.6 walleyes during April September (Table 8). For all boat and bank anglers (including those targeting walleyes), estimates of total effort and total catch were 3467.9 hours and 887.1 walleyes during October - March, and 5716.9 hours and 29.4 walleyes during April - September (Table 8).

\section{Total fishing effort from vehicle counts}

Counts of vehicles were lowest during late fall and winter and highest during spring and summer, and early fall (October) (Appendix D). The three lowest estimates of total angler effort from vehicle count data were from December (1162.4 hrs), January (55.6 hrs), and February (404.4 hrs) and the three highest estimates were from April (10767.7 hrs), May (29713.4 hrs) and June (21978.0 hrs; Table 10). All vehicles parked and counted at access sites, however, did not represent anglers; therefore, the total angler effort was likely overestimated with this method. Although the proportion of angler vehicles at access sites was not estimated, it is likely that a lower proportion of angler 
vehicles were present during the high recreation use periods of spring and summer months.

\section{Angler attitudes}

I obtained angler opinions for sizes of "keepable" and "trophy" walleyes, the quality of the walleye fishery, size and bag limit changes, and angler satisfaction of the fishing trip on the day of the interview (Appendix A). Many anglers considered the length of a "keepable" walleye to be between $12(304.8 \mathrm{~mm})$ and 15 inches $(381 \mathrm{~mm})(\mathrm{n}$ $=78$, mean $=342.9 \mathrm{~mm}$ or 13.5 inches, $\mathrm{SE}=0.57$, range from 8-28 inches; Figure 6). Anglers considered "trophy" walleyes to be $18(457.2 \mathrm{~mm})$ to 35 inches $(888.9 \mathrm{~mm})$ $(\mathrm{n}=61$, mean $=695.9 \mathrm{~mm}$ or 27.4 inches, $\mathrm{SE}=0.68 ;$ Figure 7$)$

In a two-part question related to the change in the walleye fishery within the last 5 years, anglers responded to whether the overall walleye fishing has improved ( $7 \%$ of responses), no response (7\% of responses), stayed the same (12\%), worsened (21\%), or did not know (53\%; Figure 8), and if walleye size has improved (4\%), no response (7\% of responses), stayed the same (15\%), worsened (21\%), or did not know (53\%; Figure 8 ). Angler opinions of possible future fishing regulations changes were as follows: size limit (42\% support, $4 \%$ oppose, $53 \%$ no response), bag limit (40\% support, $7 \%$ oppose, $52 \%$ no response), size and bag limit (38\% support, $4 \%$ oppose, $57 \%$ no response; Figure 9 ). Angler satisfaction with the fishing trip (on the day of the interview) ranged from low $($ rank $=1)$ to high (rank =9), with peaks for rank 1 (35 boat anglers, 17 bank anglers) and rank 3 (15 boat anglers, 9 bank anglers, Figure 10) 


\section{Angler-reported information from previous fishing trips}

I asked several questions regarding walleye angling in addition to the core set of questions (Appendix A). One set of three questions was as follows: On an average fishing trip to Summersville Reservoir, (a) what percent of all walleyes you catch do you keep?, (b) what percent of walleyes you catch are greater than 15 inches?, and (c) what percent of walleyes you catch greater than 15 inches do you keep? Responses for percentages of all walleyes kept ranged from 0 to $100 \%$ with peaks at $0 \%$ (11 boat anglers, 1 bank angler), 20\% (6 boat anglers, 4 bank anglers), 50\% (12 boat anglers, 1 bank angler), 80\% ( 7 boat anglers, 3 bank anglers), and 100\% (6 boat anglers, 4 bank anglers, Figure 11). Most responses for percentages of $>15$ inch walleyes caught were $50 \%$ or less (46 boat anglers, 18 bank anglers), with only 15 responses over $50 \%$ (12 boat anglers, 3 bank anglers, Figure 12). Responses for percentages of $>15$ inch walleyes kept ranged from 0 to $100 \%$, and the two highest frequencies of angler responses were for $0 \%$ (14 boat anglers, 1 bank anglers) and 100\% (15 boat anglers, 12 bank anglers, Figure 13). Sixty-five of 165 anglers reported that they never fish for walleyes at Summersville Reservoir, and the remaining 100 anglers reported from 1 to 300 walleye fishing trips per year at Summersville Reservoir $($ mode $=3$, mean $=28.2, \mathrm{SE}=5.02$ ).

\section{Additional questions}

Out of 144 responses, 98 indicated that they primarily fished for black bass in West Virginia, but others primarily fished for walleye $(\mathrm{n}=26)$, any species (14), catfish (12), crappie (4), hybrid striped bass (2), and sunfish (1). Anglers provided a list of other places fished for walleye: Kanawha River (14 anglers), Gauley River (9), New River (8), Ohio River (7), Elk River (4), Burnsville Tailwaters (1), and Guyandotte River (1). 
Additional reservoirs fished for walleye included Burnsville Lake (5 anglers), Stonewall Jackson Lake (4), Sutton Lake (2), R. D. Bailey Lake (1), and Stephens Lake (1).

\section{Discussion}

My data on the size of walleyes and the percent of walleyes harvested are consistent with data from previous studies during the 1980s, 1990s, and 2000s (Ramsey and Pierce 1981; Shingleton 1992, 1993; Wellman 2011). Walleyes reported during my survey period rarely exceeded 15 inches, and most (74.5\%) were harvested. All studies have reported a small-size structured population of walleyes within Summersville Reservoir. Previous studies, however, did not partition estimates of catch rates and harvest rates of walleyes between boat and bank anglers and between walleye anglers and all anglers. My data provide evidence that walleye anglers contribute to a large proportion of estimates of catch rates, harvest rates, and total catches of walleyes. Further, my study found that catch rates, harvest rates, and total catches of walleyes are highest at low water levels during the lake draw-down period, a finding consistent with that of previous studies.

Catch rates, harvest rates, and estimates of effort and catch for walleyes were highest during December and March. Also, data for November based on one weekend provided evidence that November was a month with relatively high catch rates and harvest rates of walleyes, but these data were included with December estimates. These results are not unexpected, given that walleyes are known to actively forage during late fall and winter periods, a time when many other gamefishes are less active. January and February could also be months of relatively high catch rates and harvest rates because of the colder water temperatures making them more vulnerable to anglers, but ice cover 
during these months prevented angling efforts during our study. Catch rates are expected to decrease from spring to summer if walleyes move from shallow areas to deeper pelagic areas (Deroba et al. 2007a, 2007b). Deroba (2007b) also suggested that catch rates may decline during summer when tourists and non-local anglers comprise a larger proportion of all anglers. This dilution effect on catch rates may also result from an increase in party size during warmer months, because some members in large parties are often less skilled at angling (VanDeValk et al. 2007).

Angler hours of effort based on vehicle counts are likely overestimated.

Summersville Reservoir is a multi-use recreational area, and parked vehicles could not be reasonably attributed to anglers. I initially predicted that parked vehicles during fall and winter would be associated with angling, but discovered that hiking and hunting are common fall and winter activities at the reservoir. Also, a relatively high proportion of vehicles associated with non-angling activities were present during high use times of spring and summer. Because of uncertainty of the exact recreational or other activity associated with parked vehicles, I suggest that the effort estimates based on vehicle counts (Table 10) should be used with caution.

Catch rates of walleyes from my study varied in comparison to other studies within WV reservoirs based upon the season. For April-June, estimated catch rates at Summerville Reservoir were similar between my study (0.007-0.009 walleyes/hr) and Ramsey and Pierce (1981; 0.008 walleyes/hr). For April-October, catch rates were similar between my study (0.009) and Shingleton (1992, 1993; 0.01-0.018; Table 9). For December-March, the catch rate from my study (0.353) was higher than those of Shingleton (1992, 1993; 0.058-0.148; Table 9). Monthly catch rates (estimated as total 
catch divided by total effort) for walleyes within Tygart Reservoir, WV, ranged from 0.08 to 0.61 walleyes/hr (Jernejcic 1986; Table 9). Baccante (1995) summarized walleye catch rates ranging from 0.02 to 0.61 walleyes/hr from 31 studies within Alberta, Ontario, Minnesota, Wisconsin, and northern Ohio. Catch rates from these northern fisheries, however, may not be directly comparable to those for Summersville Reservoir. Baccante (1995) indicated that low catch rate estimates can result from angler preference for artificial bait instead of live bait. My survey did not determine if anglers at Summersville Reservoir primarily used artificial or live bait.

Harvest rates also varied among the seasons of the study, and were similar to catch rates in most seasons. For April-June, the estimate of harvest rate from my study (0.00 walleyes/hr) was similar to that of Ramsey and Pierce (1981; 0.007 walleyes/hr). The harvest rate from April-October for my study (0.00 walleyes/hr) was slightly lower than that of Shingleton (1992, 1993; 0.006-0.016), but December-March had higher harvest rates (0.272, my study; 0.044-0.092, Shingleton 1992, 1993). My study, however, did not encompass the months of November and August, which affects the comparisons of catch and harvest rates among studies.

Boat anglers had higher catch rates and harvest rates than those of bank anglers during all months, except March. Most of the March catch was at the Brock's Bridge site, which is located in the headwater region of the lake (Figure 1). Spawning behavior during March likely increased walleye susceptibility to bank anglers in this area. In some fisheries, estimates of boat angler catch and harvest rates can exceed those of bank anglers, which may result from increased mobility and access, or the use of electronics by boat anglers (VanDeValk et al. 2005, Johnson et al. 1988). Also, boat angler surveys at 
access points (boat ramps) often represent completed trips, where bank angler interviews during roving surveys often represent incomplete trips. Inaccurate reporting of trip duration for incomplete trips is not expected (McEachron et al. 1986, Mallison and Cichra 2004), but catch rate estimates from complete and incomplete trips can differ (Keefe et al. 2009). During March, walleye bank anglers targeted walleyes during the peak feeding time within evening or crepuscular hours, so catch rates were relatively high for this angler group. If catch rates are higher during crepuscular hours, then data from incomplete trips may often exclude the time with higher catch rates. Boat anglers, generally do not make the trip for one or two evening hours of fishing, so catch rate and harvest rate estimates from boat anglers often include hours during the day when walleyes are not likely to be caught.

An important addition to our study, compared to previous studies, was questions regarding angler attitudes. Approximately half of all walleye anglers (18 of 31) did not catch a walleye during the fishing trip, which likely explains the high number of dissatisfied anglers (19 of 32 walleye anglers reported a low satisfaction rank of 3 or less). The general opinion of anglers who were concerned with the walleye fishery varied. Twenty-one percent of anglers reported that overall walleye fishing (number and size of fish) has worsened in the past five years, which is also another likely contributor to low satisfaction rates. But, $19 \%$ of anglers reported that the number and size of walleyes had improved or stayed the same. Many anglers were not opposed to management regulations; $91 \%, 85 \%$, and $90 \%$ of anglers (excluding those with no response) within the survey approved of bag limits, size limits, or both, respectively. 
A large percentage of anglers indicated that 14 inch and $15 \mathrm{inch}$ walleyes were "keepable" fish, but I do not know if this common angler opinion is influenced by the existing small size structure of the population, or if the angler opinion and associated harvest of 14 and 15 inch fish influence the small-size structure of the population. The percentage of fish harvested is relatively high, but the overall effort and catch seem relatively low during most months of the year. It is not known what levels of total effort and harvest rates would be required to cause growth overfishing in a walleye population in an oligotrophic reservoir, such as Summersville Reservoir.

My access site creel and angler survey was designed to obtain completed trip information from boat anglers at boat ramps, but also included a roving component of obtaining incomplete trip information from bank anglers fishing in the vicinity of boat ramps. A common concern for point-access creel surveys involves whether survey sites represent angler access. If high-use access areas are not sampled, then effort and catch estimates will be inaccurate and biased (Hayne 1991). Our spatial coverage was likely adequate, given the limited number of boat ramps, and one bank fishing site (Brocks Bridge) on the reservoir. It is possible that other areas within the reservoir were used by bank anglers or anglers in small boats (which can be launched without a boat ramp). However, much of the shoreline is wooded without road access. Also, steep banks and cliffs limit access for much of the reservoir during the water draw-down period.

My survey design of morning, mid-day, and evening rounds may have underestimated catch rates and harvest rates of the walleye fishery at Summersville Reservoir. If night fishing is common, then my design missed fish caught and harvested during that time. Walleyes are susceptible to angling during low-light hours (Ali et al. 
1997, Deroba et al. 2007, Lester et al. 2004, Niemuth et al. 1972, Olson 1958). Much of my sampling time occurred during the time of day when walleyes are not known to actively forage. A survey design that targets crepuscular hours may provide as much information at less of a cost in man-hours and travel costs. This could increase the creel clerk's ability to contact anglers specifically targeting walleye (Ali et al. 1997, Deroba et al. 2007); however, several creel clerks would be needed to simultaneously cover multiple sites.

Future studies should focus on the causal factors of low growth rates. Angler catch rates and angler satisfaction are directly influenced by walleye growth rates (VanDeValk et al. 2005). Slow rates of growth are supported by the narrow size distribution of walleye from this study, and the length-age distribution data from separate studies of Wellman (2011). One explanation for slow growth is an inadequate forage base. Shingleton $(1992,1993)$ discussed the forage base within Summersville Reservoir, and several efforts have been made to introduce emerald shiners, threadfin shad, and brook silversides, but more studies are needed to assess the forage base. Productivity also influences the forage base, and Summersville Reservoir is a low-fertile reservoir (Phosphorus, total mg/L $<0.02 ;$ Marchese 2011). High densities of fishes can also cause reduced growth rates, although we do not have estimates of walleye densities within the reservoir. Also, overfishing could explain the current size structure, given that walleyes with faster growth would have a higher probability of being harvested. This could cause selection against faster growing individuals within the population.

Walleye mortality associated with passage through the dam outlet should be another focus for future research, because dam-induced mortality could be associated 
with the perceived low growth rate and the small size structure of walleyes. Ramsey and Pierce (1981) predicted 100\% mortality for fish passing through the Howell Bunger outlet structure of Summersville Dam. Fish mortality has been noted downstream of the dam, with dead walleyes as the most frequently encountered (Ramsey and Pierce 1981). This is likely to occur infrequently, but could have an effect if there are an abundance of walleye in the area during a larger than normal outflow event. Jernejcic (1986) reported walleye migration through Tygart Dam, another reservoir within West Virginia, where walleyes $\leq$ age 2 migrated out of the lake using the tail-water dam. We do not have historic or recent estimates of dam-induced mortality of walleyes. Further research is needed to determine the extent of dam-induced mortality of walleyes.

The slow growth rates of walleyes within Summersville Reservoir are a management concern, and likely influenced my data from creel and angler surveys. Although anglers harvest a high percentage of the walleye catch, the catch rates and harvest rates are low relative to those reported from other walleye fisheries. However, Summersville Reservoir is a small, oligotrophic system with low productivity (Marchese 2011), and low catch and harvest rates may be common for this fishery. The walleye fishery in Summersville Reservoir is seasonal, and catch and harvest rates and total effort and total catch are highest during the water level draw-down period which extends from September to April. Slow growth rates, lack of "trophy-sized" fish, and small size structure of the walleye population are likely associated with angler dissatisfaction. Future research on diets, food availability, and movements (daily and seasonally) would be useful toward answering questions about growth rates and size structure of walleyes within Summersville Reservoir. 


\section{Literature cited}

Ali, M.A., R. A. Ryder, and M. Anctil. 1997. Photoreceptors and visual pigments as related to behavioral responses and preferred habitat of perches (Perca spp.) and pikeperches (Stizostedion spp.). Journal of the Fisheries Research Board of Canada 34:1475-1480.

Baccante, D. 1995. Assessing catch inequality in walleye angling fisheries. North American Journal of Fisheries Management 15:661-665.

Deroba, J.J., Hansen M.J., Nate, N.A., Hennessy, J.M. 2007a. Temporal profiles of walleye angling effort, harvest rate, and harvest in Northern Wisconsin Lakes. North American Journal of Fisheries Management 27:717-727.

Deroba, J.J., Hansen M.J., Nate, N.A., Hennessy, J.M. 2007b. Evaluating creel survey efficiency for estimating walleye fishery metrics in northern Wisconsin lakes. North American Journal of Fisheries Management 27:707-716.

Hayne, D.W. 1991. The access point creel survey: Procedures and comparison with the roving-clerk survey. Pages 123-138 in D. Guthrie, J.M. Hoenig, M. Holliday, C.M. Jones, M.J. Mills, S.A. Moberly, K.H. Pollock, and D. R. Talhelm, editors. Creel and angler surveys in fisheries management. American Fisheries Society, Symposium 12.

Hoenig, J.M., C.M. Jones, K.H. Pollock, D.S. Robson, and D.L. Wade. 1997. Calculation of catch rate and total catch in roving surveys of anglers. Biometrics 53:306-317.

Jernejcic, F. 1986. Walleye migration through Tygart Dam and angler utilization of the resulting tailwater and lake fisheries. Pgs. 294-300 in G.E. Hall and M.J. Van Den Avyle, editors. Reservoir Fisheries Management: Strategies for the 80's. Reservoir Committee, Southern Division American Fisheries Society 294-300.

Johnson, B. L., D.L. Smith, and R. F. Carline. 1988. Habitat preferences, survival, growth, foods, and harvests of walleyes and walleye X sauger hybrids. North American Journal of Fisheries Management 8:292-304.

Keefe, D.G., R.C. Perry, and J.G. Luther. 2009. A comparison of two methodologies for estimating brook trout catch and harvest rates using incomplete and complete fishing trips. North American Journal of Fisheries Management 29:1058-1064.

Lester, N.P., A. J. Dextrase, R. S. Kushneriuk, M. R. Rawson, P. A. Ryan. 2004. Light and temperature: key factors affecting walleye abundance and production. Transactions of the American Fisheries Society 133:588-605. 
Mallison, C.T. and C.E. Cichra. 2004. Accuracy of angler-reported harvest in roving creel surveys. North American Journal of Fisheries management 24:880-889.

Marchese, V. 2011. Summersville Lake, WV water quality and flushing rate data. United States Army Corps of Engineers.

McEachron, L.W., G.E. Saul, and S.J. Gutreuter. 1986. Accuracy of trip durations reported by marine sport-boat fishermen. North American Journal of Fisheries Management 6:59-62.

Niemuth, W., W. Churchill, and T. Wirth. 1972. Walleye: its life history, ecology, and management. Wisconsin Department of Natural Resources, Publication 227-272.

Olson, D.E. 1958. Statistics of a walleye sport fishery in a Minnesota Lake. Transactions of the American Fisheries Society 87:52-72.

Pierce, B.E. 1977. Reservoir investigations, Summersville Lake study, West Virginia Department of Natural Resources, D-J Report, Project F-11-R-15.

Pollock, K.H., J.M. Hoenig, C.M. Jones, D.S. Robson, C.J. Greene. 1997. Catch rate estimation for roving and access point surveys. North American Journal of Fisheries Management 17:11-19.

Pollock, K.H., C.M. Jones, and T.L. Brown. 1994. Angler survey methods and their applications in fisheries management. American Fisheries Society, Special Publication 25, Bethesda, Maryland. 156-157.

Ramsey, D. and B. Pierce. 1981. Reservoir investigations, Summersville Reservoir study for period of January 1, 1980-December 31 1980, West Virginia Division of Natural Resources, D-J Report, Project F-11-R-19.

Shingleton, M.V. 1992. Reservoir investigations, Summersville Lake study for period of January 1, 1991 - December 31, 1991, West Virginia Department of Natural Resources, D-J Report, Project F-11-R-30.

Shingleton, M.V. 1993. Reservoir investigations, Summersville Lake study for period of January 1, 1992 - December 31, 1992, West Virginia Department of Natural Resources, D-J Report, Project F-11-R-31.

VanDeValk A.J., J.L. Forney, J.R. Jackson, L.G. Rudstom, T.E. Brooking, and S.D. Krueger. 2005. Angler catch rates and catchability of walleyes in Oneida Lake, NY. North American Journal of Fisheries Management 25:1441-1447.

VanDeValk A.J., J.R. Jackson, S.D. Krueger, T.E. Brooking, and L.G. Rudstom. 2007. Influence of party size and trip length on angler catch rates on Oneida Lake, New York. North American Journal of Fisheries Management 27:127-136. 
Wellman, D.I. 2011. Walleye population and stocking density assessment. West Virginia Division of Natural Resources. Federal aid year-end report 2010. Reservoir Project F-11-R. 

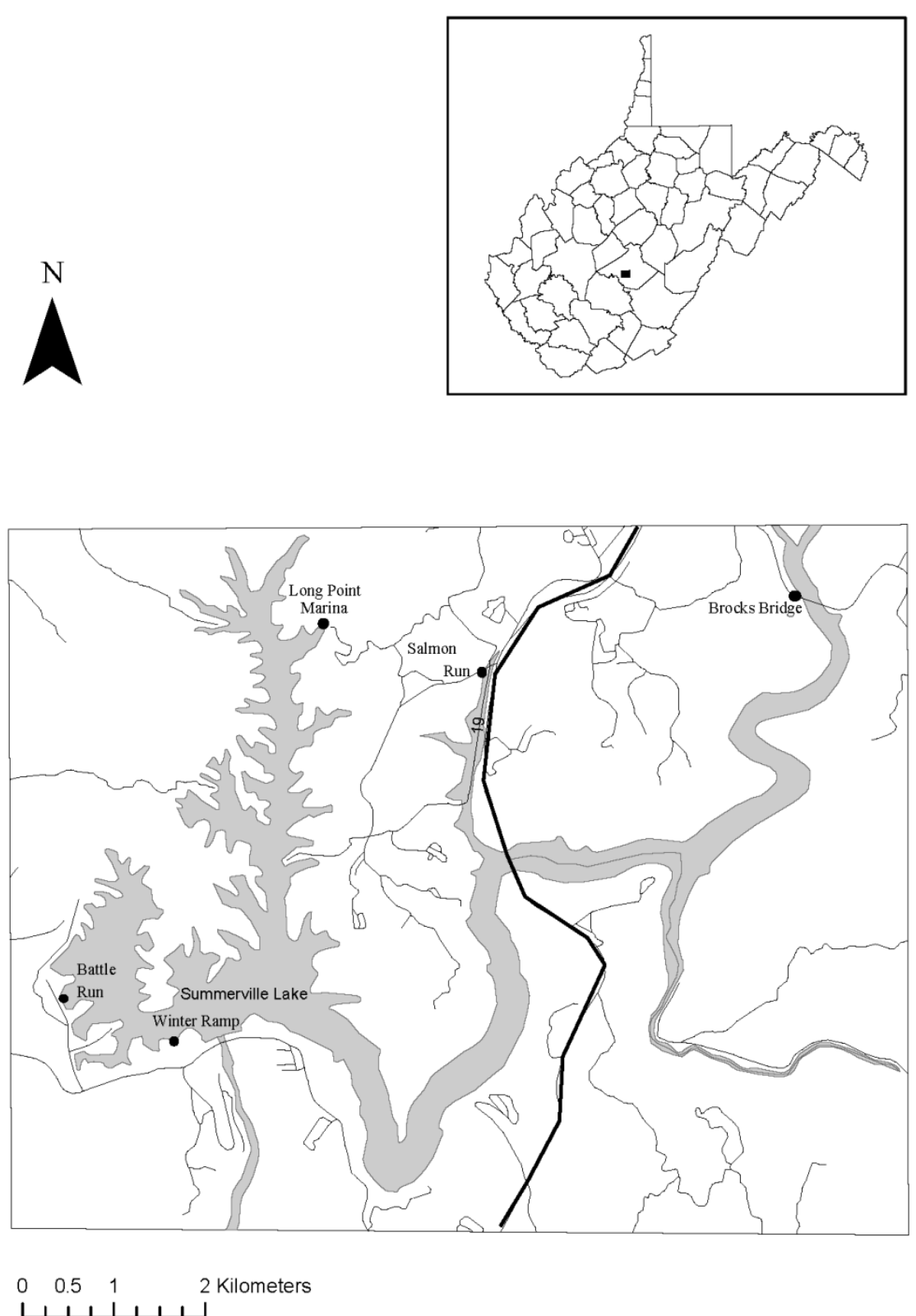

Figure 1. Summersville Reservoir and the locations of access roads and boat ramps. 


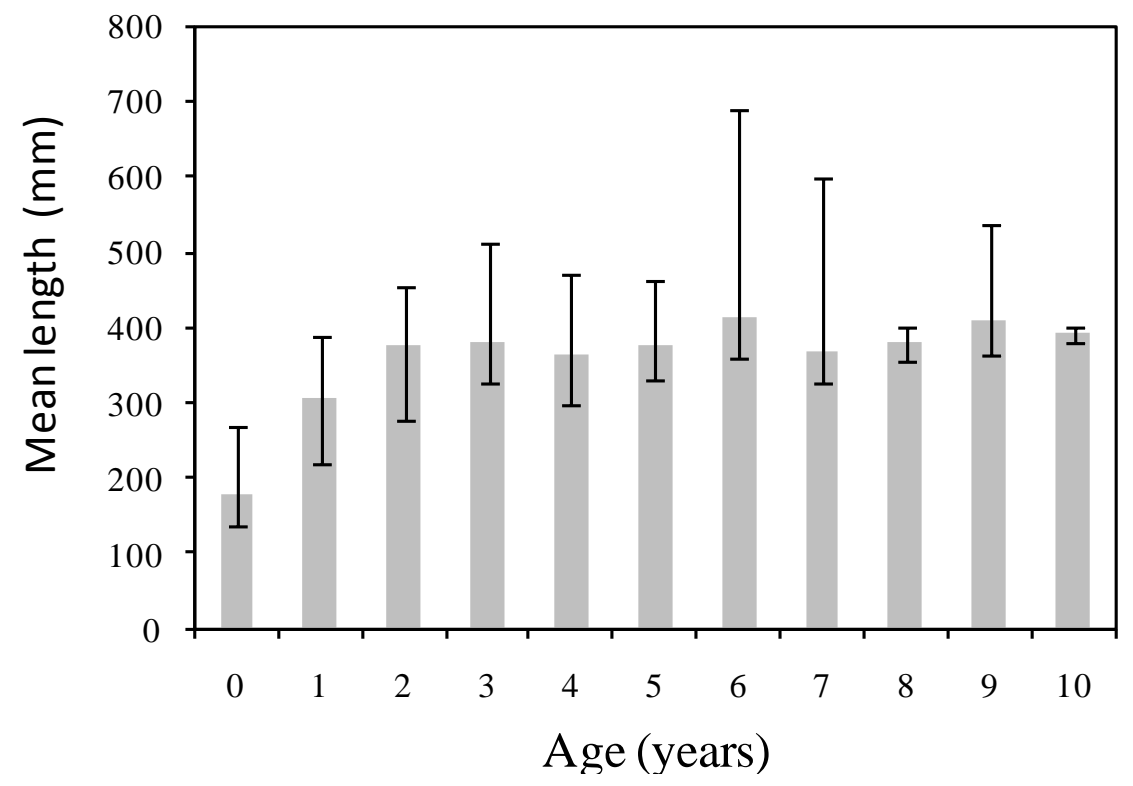

Figure 2. Mean length-at-age data from 2008, 2009, and 2010 walleye assessments of Summersville Reservoir (reprinted from Wellman 2011). 


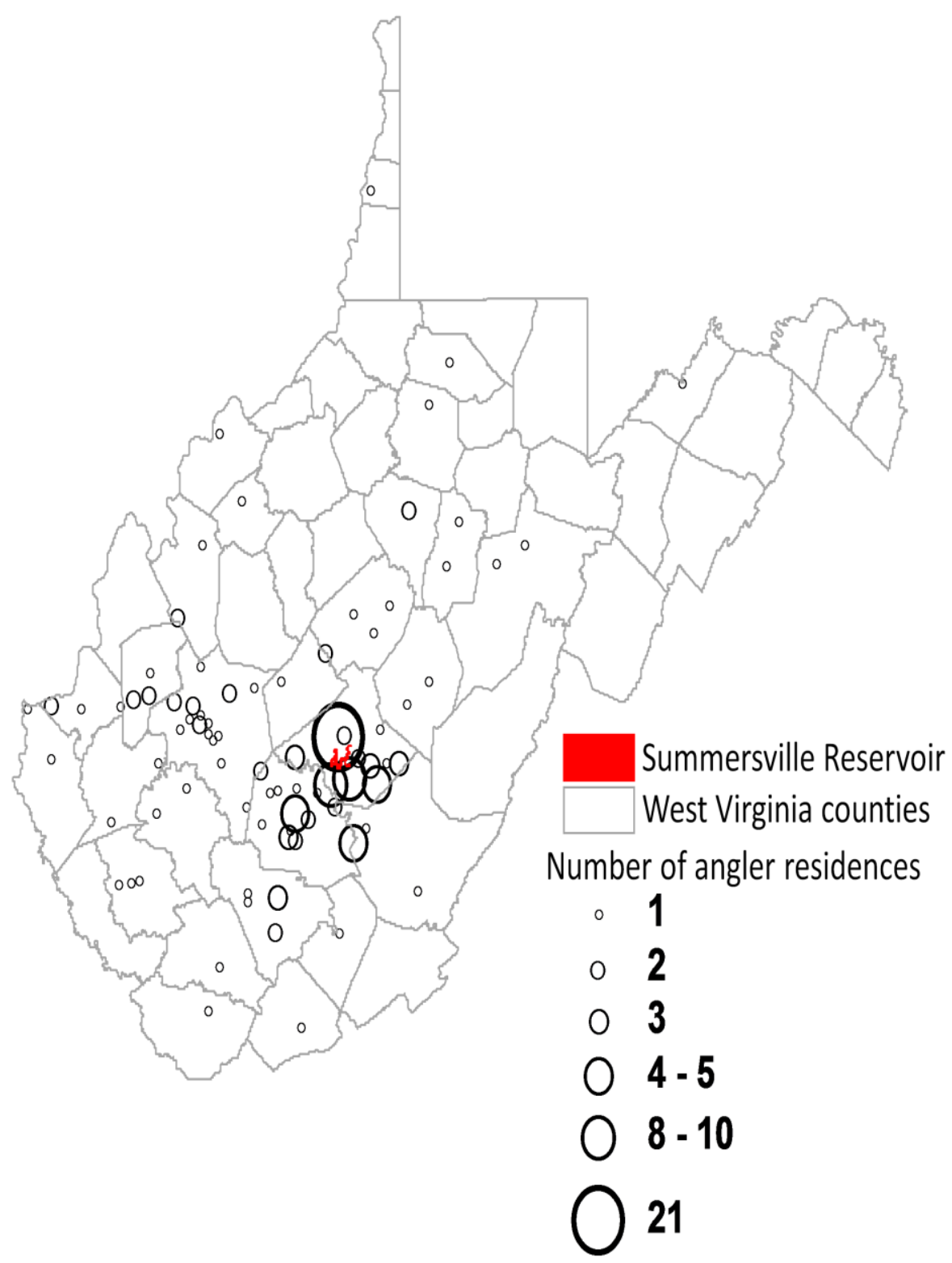

Figure 2. Geographic distribution of angler residences (zip codes). Zip codes of four nonresident anglers were not plotted (Belpre, OH; Elyria, OH; Humble, TX; and Manor, TX). 


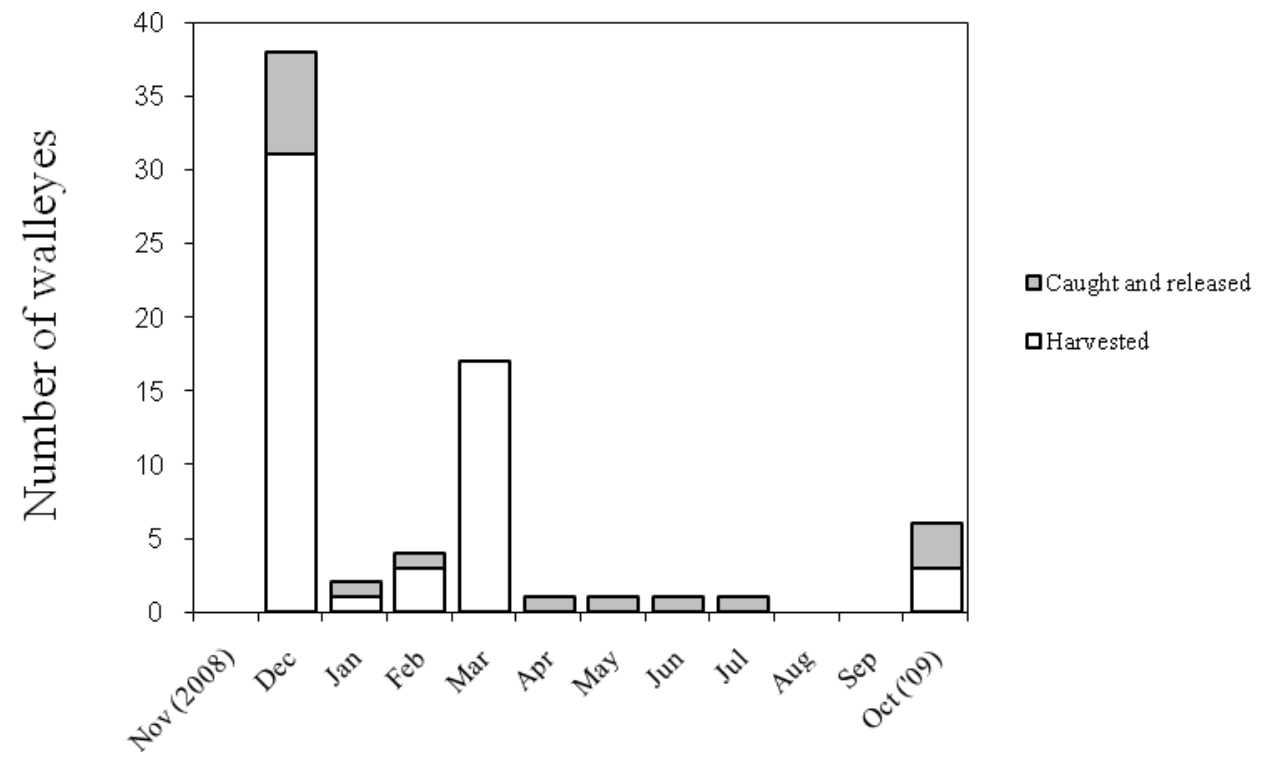

Figure 3. Number of walleyes caught and harvested by month at Summersville Reservoir based on creel and angler surveys. Surveys were not conducted for November and August; no walleyes were reported during September surveys.

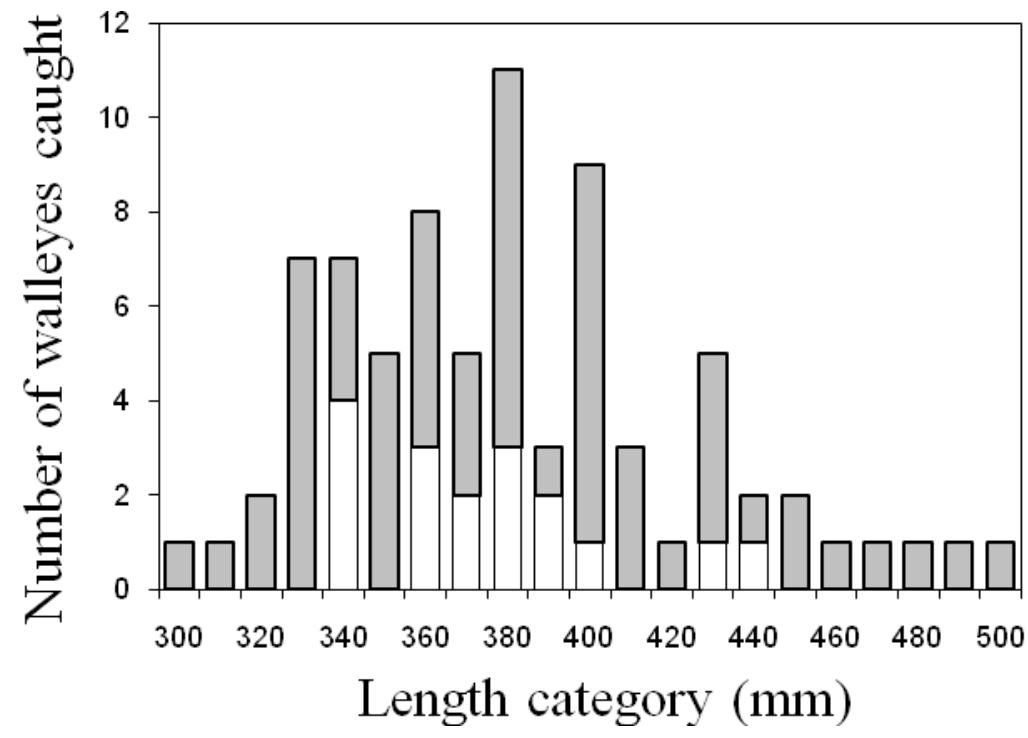

$\square$ B oat anglers

$\square$ Bank anglers

Figure 4. Length frequency of walleyes caught by boat and bank anglers based on fish measured during the creel survey. 


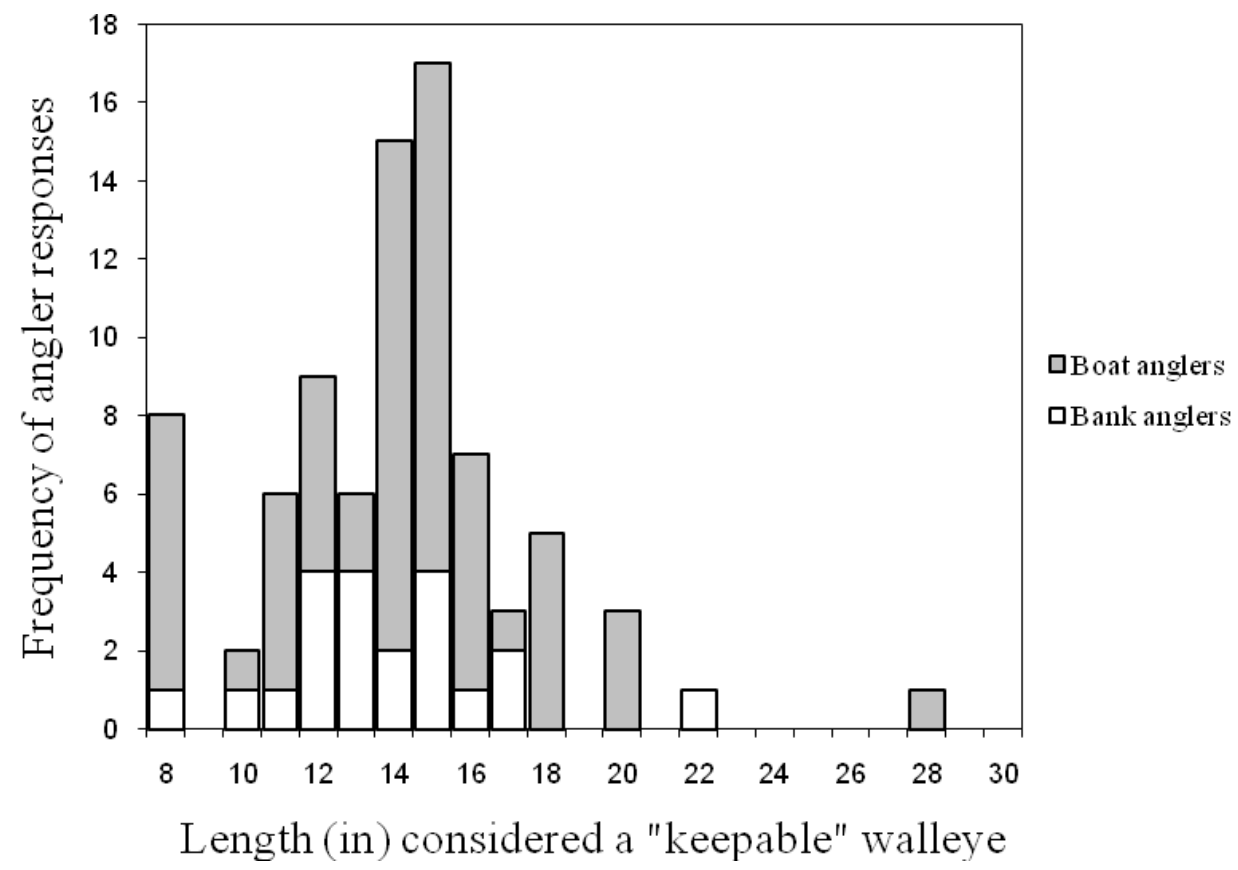

Figure 5. Lengths considered by anglers to be "keepable" walleyes.

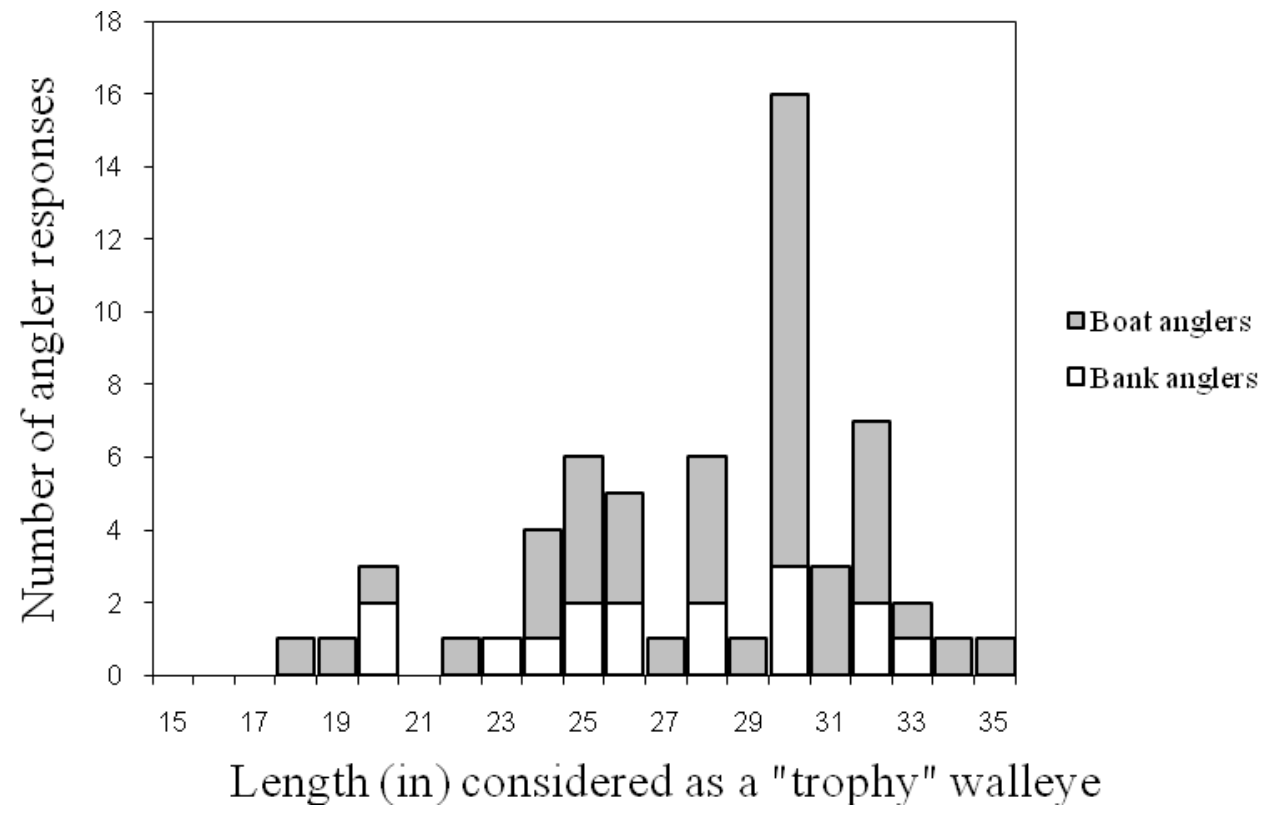

Figure 6. Lengths considered by anglers to be "trophy" walleyes. 
A

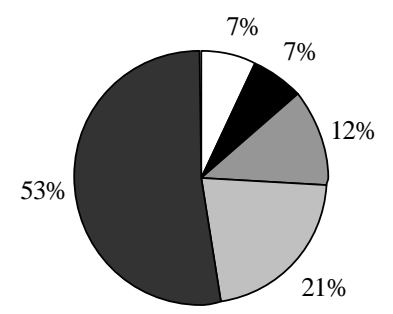

B

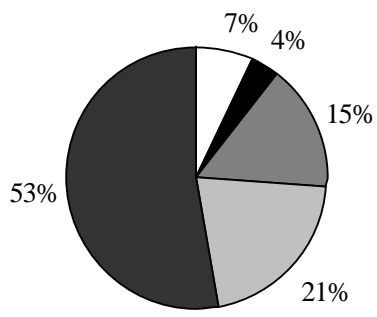

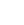

Figure 7. Angler responses to (A) changes in the overall walleye fishery during the last five years, and (B) changes to the size of walleyes during the last five years.

A

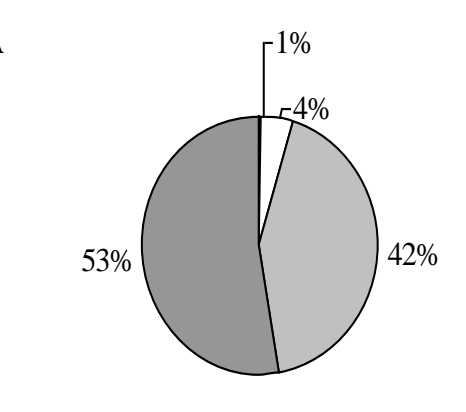

A $\square$ Does not know

- improved

$\square$ Stayed the same

$\square$ Worsened

- No response

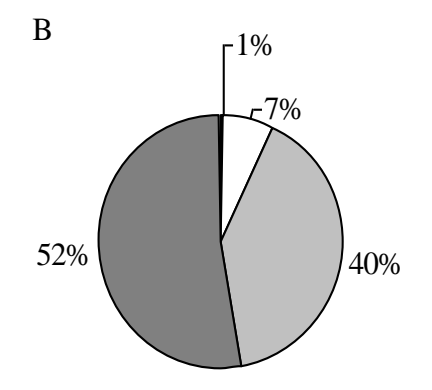

$\mathrm{C}$
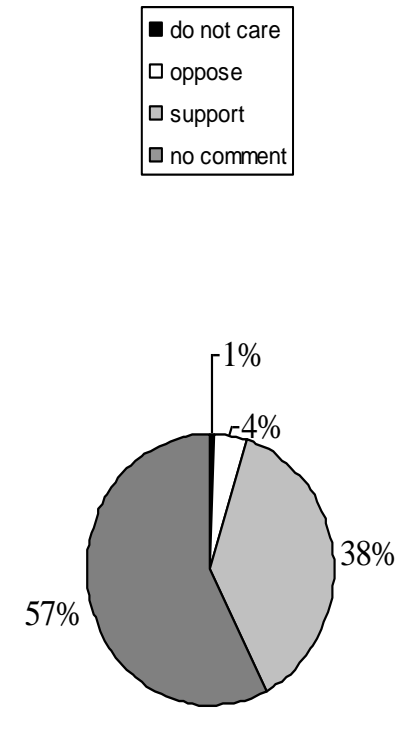

Figure 8. Angler opinions on changes to the walleye fishing regulations, such as (A) size limits, (B) bag limits, and (C) size and bag limits. 


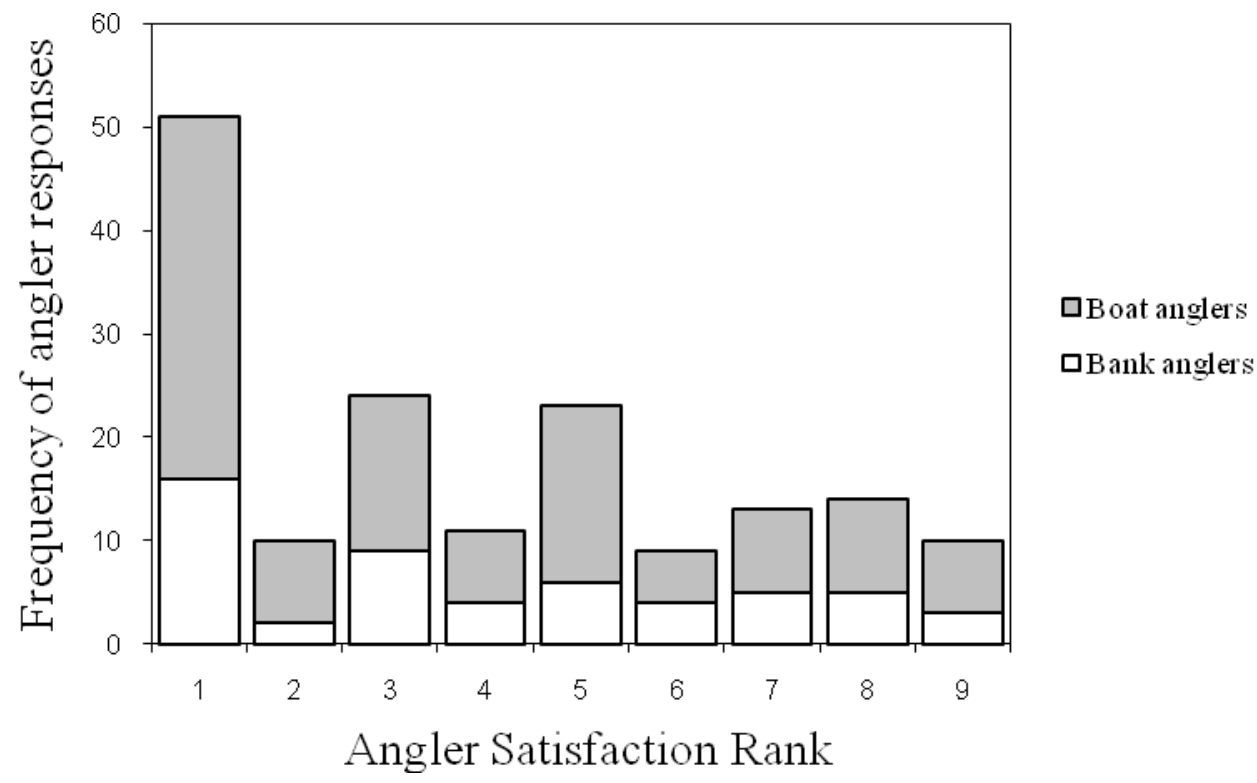

Figure 9. Rank of angler satisfaction of the fishing trip (on the day of interview), where a rank of 1 means extremely dissatisfied and a rank of 9 means extremely satisfied.

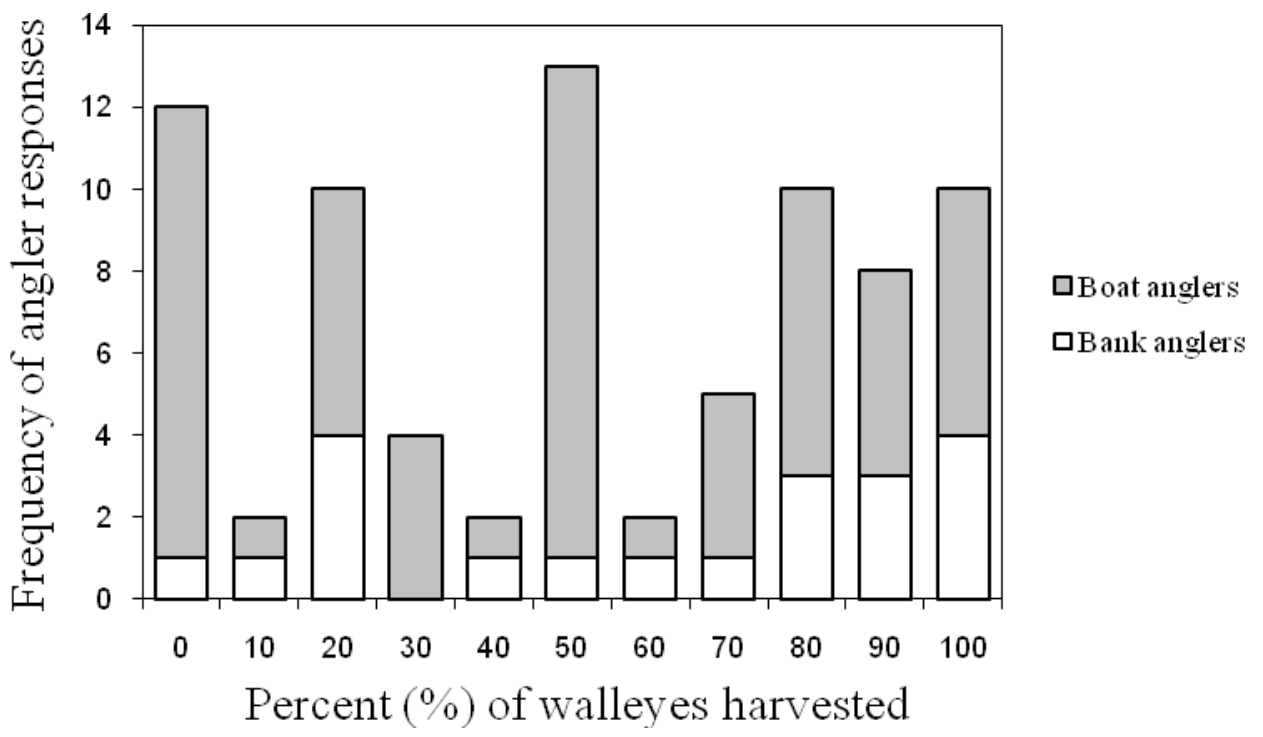

Figure 10. Percent of walleye harvested from all walleye caught. 


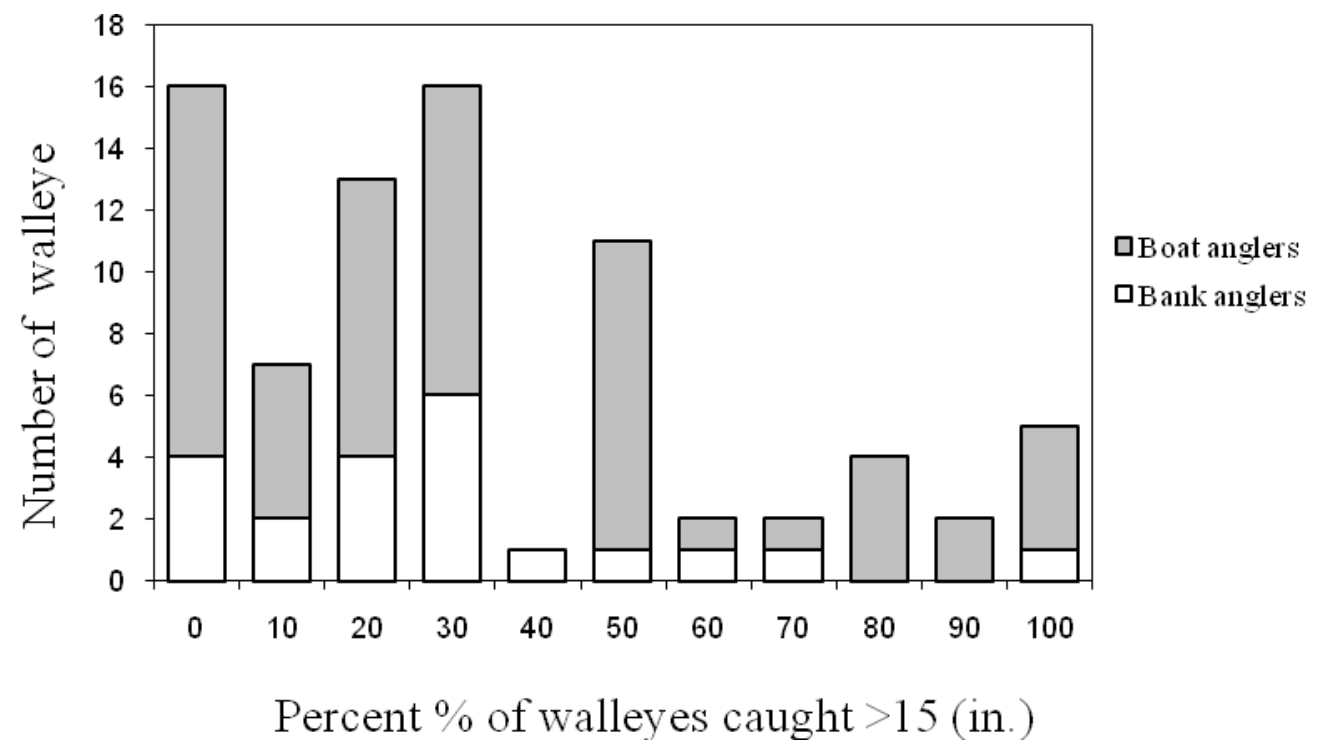

Figure 11. Percent of all walleye caught greater than 15 inches.

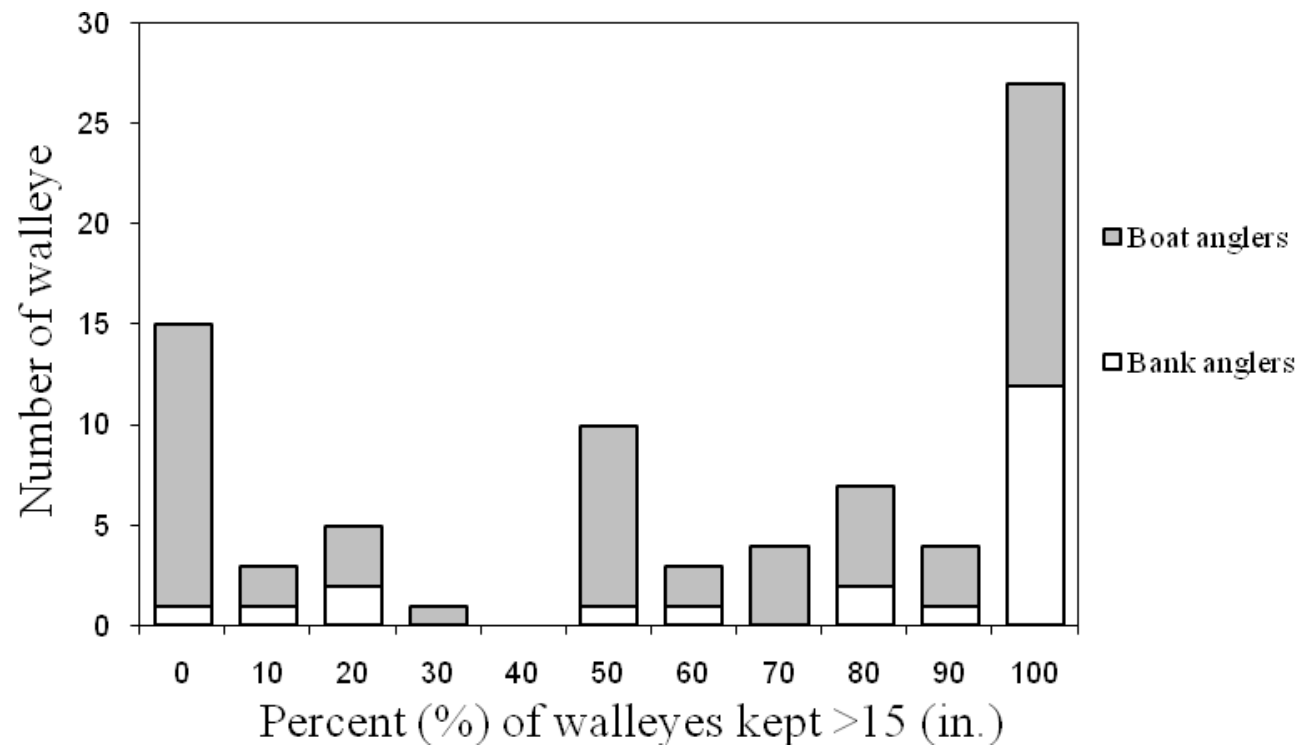

Figure 12. Percent of walleye kept from walleye caught greater than 15 inches. 
Table 1. Residences of surveyed anglers and the estimated time ( $\mathrm{min})$ and distance $(\mathrm{km})$ of travel to Summersville, WV.

\begin{tabular}{|c|c|c|c|}
\hline Town & Time & Kilometers & Frequency \\
\hline Ansted, WV & 28 & 38.6 & 1 \\
\hline Barboursville, WV & 126 & 210.8 & 1 \\
\hline Beckley, WV & 53 & 75.6 & 3 \\
\hline Belle, WV & 80 & 96.5 & 1 \\
\hline Buchannon, WV & 141 & 133.5 & 1 \\
\hline Burnwell, WV & 64 & 80.5 & 1 \\
\hline Cannelton, WV & 61 & 72.4 & 2 \\
\hline Canvas, WV & 12 & 11.3 & 2 \\
\hline Charleston, WV & 88 & 144.8 & 14 \\
\hline Charlton Heights, WV & 50 & 61.1 & 1 \\
\hline Charmco, WV & 47 & 51.5 & 1 \\
\hline Clendenin, WV & 74 & 114.2 & 1 \\
\hline Coal City, WV & 70 & 93.3 & 2 \\
\hline Craigsville, WV & 28 & 27.4 & 1 \\
\hline Culloden, WV & 117 & 188.3 & 1 \\
\hline Danville, WV & 116 & 191.5 & 1 \\
\hline Duck, WV & 49 & 70.8 & 2 \\
\hline Edmond, WV & 30 & 41.8 & 2 \\
\hline Elizabeth, WV & 149 & 173.8 & 1 \\
\hline Elkins, WV & 105 & 117.5 & 1 \\
\hline Elkview, WV & 17 & 127.1 & 2 \\
\hline Fairdale, WV & 72 & 93.3 & 1 \\
\hline Farmington, WV & 122 & 188.3 & 1 \\
\hline Fayetteville, WV & 27 & 40.2 & 5 \\
\hline Fenwick, WV & 36 & 35.4 & 1 \\
\hline Flatwoods,WV & 44 & 66.0 & 1 \\
\hline French Creek, WV & 92 & 117.5 & 1 \\
\hline Gassaway, WV & 44 & 61.1 & 1 \\
\hline Given, WV & 120 & 189.9 & 2 \\
\hline Glen Daniel, WV & 68 & 90.1 & 1 \\
\hline Harts, WV & 144 & 231.7 & 1 \\
\hline Hico, WV & 21 & 29.0 & 1 \\
\hline Hinton, WV & 88 & 128.7 & 1 \\
\hline Holden, WV & 142 & 236.5 & 1 \\
\hline Huntington, WV & 138 & 228.5 & 2 \\
\hline Hurricane, WV & 112 & 185.0 & 2 \\
\hline Kanawha Falls, WV & 47 & 56.3 & 1 \\
\hline Kenova, WV & 141 & 236.5 & 1 \\
\hline Keslers Cross Lanes, WV & 23 & 22.5 & 2 \\
\hline
\end{tabular}


Table 1. Continued.

\begin{tabular}{|c|c|c|c|}
\hline Keyser, WV & 210 & 336.3 & 1 \\
\hline Kincaid, WV & 54 & 67.6 & 1 \\
\hline Leivasy, WV & 29 & 30.6 & 5 \\
\hline Lewisburg, WV & 76 & 91.7 & 1 \\
\hline Lochgelly, WV & 34 & 48.3 & 1 \\
\hline Logan, WV & 143 & 236.5 & 1 \\
\hline Lumberport, WV & 105 & 164.1 & 1 \\
\hline Mabie, WV & 107 & 170.6 & 1 \\
\hline Minden, WV & 38 & 53.1 & 2 \\
\hline Mount Lookout, WV & 16 & 19.3 & 10 \\
\hline Mount Nebo, WV & 12 & 12.9 & 8 \\
\hline Nallen, WV & 26 & 29.0 & 6 \\
\hline Oak Hill, WV & 35 & 51.5 & 3 \\
\hline Parkersburg, WV & 154 & 262.3 & 1 \\
\hline Peytona, WV & 98 & 119.1 & 1 \\
\hline Pineville, WV & 100 & 123.9 & 1 \\
\hline Princeton, WV & 87 & 138.4 & 1 \\
\hline Procious, WV & 79 & 107.8 & 1 \\
\hline Rainelle, WV & 50 & 62.8 & 4 \\
\hline Richwood, WV & 42 & 40.2 & 3 \\
\hline Sandyville, WV & 130 & 215.6 & 1 \\
\hline Scott Depot, WV & 109 & 175.4 & 2 \\
\hline Stollings, WV & 146 & 238.1 & 1 \\
\hline Sumerco, WV & 115 & 177.0 & 1 \\
\hline Summersville, WV & 3 & 1.6 & 21 \\
\hline Sutton, WV & 40 & 57.9 & 1 \\
\hline Swiss, WV & 40 & 35.4 & 3 \\
\hline Upperglade, WV & 48 & 46.7 & 1 \\
\hline Wayne, WV & 164 & 249.4 & 1 \\
\hline Webster Springs, WV & 63 & 64.4 & 1 \\
\hline Welch, WV & 136 & 154.5 & 1 \\
\hline Weston, WV & 73 & 114.2 & 2 \\
\hline Wheeling, WV & 194 & 323.4 & 1 \\
\hline Winfield, WV & 116 & 181.8 & 1 \\
\hline Mean values for $\mathrm{WV}$ & 56.5 & 82.7 & \\
\hline \multicolumn{4}{|l|}{ Out-of-state } \\
\hline Belpre, OH & 156 & 263.9 & 1 \\
\hline Elyria, $\mathrm{OH}$ & 333 & 542.2 & 1 \\
\hline Humble, TX & 1145 & 1950.1 & 1 \\
\hline Manor, TX & 1227 & 2143.2 & 1 \\
\hline
\end{tabular}


Table 2. Percent of anglers that targeted four fisheries (walleye, black bass, crappie, and sunfish) or did not target a specific fishery (Any species) within Summersville Reservoir.

\begin{tabular}{lcc}
\hline Fisheries target & Angler surveys & Percent \\
\hline Walleye & 31 & 18.8 \\
Black Bass & 75 & 45.5 \\
Any species & 53 & 32.1 \\
Crappie & 4 & 2.4 \\
Sunfish & 2 & 1.2 \\
\hline
\end{tabular}

Table 3. Frequency of any species, black bass, and walleye fisheries targeted by month (November 2008-October 2009).The November period represents two survey days. There were no surveys during the month of August.

\begin{tabular}{cccc}
\hline Month & Any species & Black bass & Walleye \\
\hline Nov & 1 & 2 & 1 \\
Dec & 3 & 2 & 3 \\
Jan & 1 & 0 & 1 \\
Feb & 1 & 0 & 2 \\
Mar & 1 & 5 & 7 \\
Apr & 9 & 14 & 3 \\
May & 15 & 25 & 3 \\
June & 9 & 8 & 4 \\
July & 5 & 5 & 3 \\
September & 4 & 3 & 1 \\
October & 4 & 10 & 3 \\
\hline
\end{tabular}


Table 4. Monthly catch rates and harvest rates of anglers targeting walleye estimated from boat (complete trips) and bank (incomplete trips) angler survey data at Summersville Reservoir, WV. Number of interviews followed by standard error are given in parentheses. An asterisk (*) indicates that no anglers were encountered during the survey period.

\begin{tabular}{|c|c|c|c|c|c|c|c|c|}
\hline \multirow[b]{3}{*}{ Month/yr } & \multicolumn{4}{|c|}{ Boat anglers } & \multicolumn{4}{|c|}{ Bank anglers } \\
\hline & \multicolumn{2}{|c|}{ Catch rate } & \multicolumn{2}{|c|}{ Harvest rate } & \multicolumn{2}{|c|}{ Catch rate } & \multicolumn{2}{|c|}{ Harvest rate } \\
\hline & Weekday & Weekend & Weekday & Weekend & Weekday & Weekend & Weekday & Weekend \\
\hline Dec-08 & $0.94(2,0.44)$ & $1.10(3,0.49)$ & $0.58(2,0.30)$ & $0.81(3,0.36)$ & $*$ & $*$ & $*$ & $*$ \\
\hline Jan-09 & $*$ & $0.20(1,3)$ & $*$ & $0.00(1,0.00)$ & $*$ & $0.20(1,0.04)$ & $*$ & $0.20(1,0.04)$ \\
\hline Feb-09 & $0.22(2,0.28)$ & $*$ & $0.00(2,0.00)$ & $*$ & $*$ & $*$ & $*$ & \\
\hline Mar-09 & $*$ & $0.00(2,0.00)$ & $*$ & $0.00(2,0.00)$ & $0.88(2,0.02)$ & $0.26(3,0.53)$ & $0.88(2,0.02)$ & $0.26(3,0.53)$ \\
\hline Apr-09 & $*$ & $0.00(1,0.00)$ & $*$ & $0.00(1,0.00)$ & $*$ & $0.62(2,0.62)$ & $*$ & $0.00(2,0.00)$ \\
\hline May-09 & $0.20(1,1.6)$ & $0.00(2,0.00)$ & $0.00(1,0.00)$ & $0.00(2,0.00)$ & $*$ & $*$ & $*$ & $*$ \\
\hline Jun-09 & $0.00(1,0.00)$ & $0.04(3,0.14)$ & $0.00(1,0.00)$ & $0.00(3,0.00)$ & $*$ & $*$ & $*$ & $*$ \\
\hline Jul-09 & $0.00(1,0.00)$ & $0.00(1,0.00)$ & $0.00(1,0.00)$ & $0.00(1,0.00)$ & $*$ & $0.00(1,0.00)$ & $*$ & $0.00(1,0.00)$ \\
\hline Sep-09 & $*$ & $0.00(1,0.00)$ & $*$ & $0.00(1,0.00)$ & $*$ & $*$ & $*$ & $*$ \\
\hline Oct-09 & $0.00(1,0.00)$ & $0.34(2,0.37)$ & $0.00(1,0.00)$ & $0.26(2,0.32)$ & $*$ & $*$ & $*$ & $*$ \\
\hline
\end{tabular}


Table 5. Monthly catch rates and harvest rates for all anglers estimated from boat (complete trips) and bank (incomplete trips) angler survey data from Summersville Reservoir, WV. Number of interviews followed by standard error are given in parentheses. An asterisk $(*)$ indicates that no anglers were encountered during the survey period.

\begin{tabular}{|c|c|c|c|c|c|c|c|c|}
\hline \multirow[b]{3}{*}{ Month/yr } & \multicolumn{4}{|c|}{ Boat anglers } & \multicolumn{4}{|c|}{ Bank anglers } \\
\hline & \multicolumn{2}{|c|}{ Catch rate } & \multicolumn{2}{|c|}{ Harvest rate } & \multicolumn{2}{|c|}{ Catch rate } & \multicolumn{2}{|c|}{ Harvest rate } \\
\hline & Weekday & Weekend & Weekday & Weekend & Weekday & Weekend & Weekday & Weekend \\
\hline Dec-08 & $0.53(5,0.25)$ & $0.52(7,0.57)$ & $0.46(5,0.28)$ & $0.45(7,0.59)$ & $0.00(1,0.00)$ & $0.00(1,0.00)$ & $0.00(1,0.00)$ & $0.00(1,0.00)$ \\
\hline Jan-09 & $*$ & $0.13(2,2.9)$ & $*$ & $0.07(2,2.3)$ & $*$ & $0.20(1,0.20)$ & $*$ & $0.20(1,0.20)$ \\
\hline Feb-09 & $0.09(3,0.16)$ & $*$ & $0.09(3,0.16)$ & $*$ & $*$ & $*$ & $*$ & $*$ \\
\hline Mar-09 & $*$ & $0.24(8,0.15)$ & $*$ & $0.03(8,0.05)$ & $0.88(2,0.02)$ & $0.26(3,0.53)$ & $0.88(2,0.02)$ & $0.26(3,0.53)$ \\
\hline Apr-09 & $0.00(1,0.00)$ & $0.00(12,0.00)$ & $0.00(1,0.00)$ & $0.00(12,0.00)$ & $0.08(7,0.50)$ & $0.07(5,0.27)$ & $0.00(7,0.00)$ & $0.00(5,0.00)$ \\
\hline May-09 & $0.02(7,0.05)$ & $0.00(26,0.00)$ & $0.08(7,0.00)$ & $0.00(26,0.00)$ & $0.00(2,0.00)$ & $0.00(10,0.00)$ & $0.00(2,0.00)$ & $0.00(10,0.00)$ \\
\hline Jun-09 & $0.00(3,0.00)$ & $0.01(8,0.03)$ & $0.00(3,0.00)$ & $0.00(8,0.00)$ & $0.00(5,0.00)$ & $0.00(6,0.00)$ & $0.00(5,0.00)$ & $0.00(6,0.00)$ \\
\hline Jul-09 & $0.00(1,0.00)$ & $0.00(5,0.00)$ & $0.00(1,0.00)$ & $0.00(5,0.00)$ & $0.00(4,0.00)$ & $0.01(5,0.001)$ & $0.00(4,0.00)$ & $0.01(5,0.001)$ \\
\hline Sep-09 & $0.00(3,0.00)$ & $0.00(3,0.00)$ & $0.00(3,0.00)$ & $0.00(3,0.00)$ & $0.00(2,0.00)$ & $*$ & $0.00(2,0.00)$ & $*$ \\
\hline Oct-09 & $0.00(3,0.00)$ & $0.04(14,0.04)$ & $0.00(3,0.00)$ & $0.02(14,0.03)$ & $*$ & $0.00(1,0.00)$ & $*$ & $0.00(1,0.00)$ \\
\hline
\end{tabular}


Table 6. Total fishing effort and total catch for boat anglers estimated with angler survey data from Summersville Reservoir, WV. Standard errors are given in parentheses. An asterisk $\left(^{*}\right)$ indicates that no anglers were encountered during the survey period.

\begin{tabular}{|c|c|c|c|c|c|c|c|c|c|c|c|c|}
\hline \multirow[b]{3}{*}{ Month/yr } & \multicolumn{6}{|c|}{ Boat Angler Effort (hours) } & \multicolumn{6}{|c|}{ Boat Angler Catch } \\
\hline & \multicolumn{3}{|c|}{ Walleye anglers } & \multicolumn{3}{|c|}{ All anglers } & \multicolumn{3}{|c|}{ Walleye anglers } & \multicolumn{3}{|c|}{ All anglers } \\
\hline & Weekday & Weekend & Total & Weekday & Weekend & Total & Weekday & Weekend & Total & Weekday & Weekend & Total \\
\hline Dec-08 & $625(101.1)$ & $103.3(32.1)$ & $728.3(106.1)$ & $745(64.9)$ & $407.7(112.4)$ & $1152.7(128.2)$ & $587(98.9)$ & $37.5(22.0)$ & $624.5(101.3)$ & $397.7(54.2)$ & $212.1(68.4)$ & $609.8(87.2)$ \\
\hline Jan-09 & $*$ & $37.8(6.5)$ & $37.8(6.5)$ & $*$ & $112.4(23.8)$ & $112.4(23.8)$ & $*$ & $7.6(2.5)$ & $7.6(2.5)$ & $*$ & $15.2(3.2)$ & $15.2(3.2)$ \\
\hline Feb-09 & $259(90.4)$ & $*$ & $259(90.4)$ & $509(536.6)$ & $*$ & $509(536.6)$ & $56.5(20.7)$ & * & $56.5(20.7)$ & $45.5(20.7)$ & $*$ & $45.5(20.7)$ \\
\hline Mar-09 & $*$ & $109(59.2)$ & $109(59.2)$ & $*$ & $509.3(17.3)$ & $509.3(17.3)$ & $*$ & $0.00(0.00)$ & $0.00(0.00)$ & $*$ & $120(19.2)$ & $120(19.2)$ \\
\hline Apr-09 & $*$ & $93.3(93.3)$ & $93.3(93.3)$ & $110.5(110.5)$ & $696.7(45.3)$ & $807.2(58.1)$ & $*$ & $0.00(0.00)$ & $0.00(0.00)$ & $0.00(0.00)$ & $0.00(0.00)$ & $0.00(0.00)$ \\
\hline May-09 & $68.2(11.3)$ & $122.2(113.3)$ & $190.4(113.8)$ & $669.8(61.03)$ & $1359.8(59.4)$ & $2029.6(85.2)$ & $15.2(2.5)$ & $0.00(0.00)$ & $15.2(2.5)$ & $13.5(4.20)$ & $0.00(0.00)$ & $13.5(4.20)$ \\
\hline Jun-09 & $281.2(281.2)$ & $147.3(35.9)$ & $428.5(283.5)$ & $565.6(84.7)$ & $262.5(35.6)$ & $828.1(91.9)$ & $0.00(0.00)$ & $6.1(2.10)$ & $6.1(2.10)$ & $0.00(0.00)$ & $3.5(2.20)$ & $3.5(2.20)$ \\
\hline Jul-09 & $170.5(170.5)$ & $3(3)$ & $173.5(170.5)$ & $170.5(170.5)$ & $402.9(49.3)$ & $573.4(177.5)$ & $0.00(0.00)$ & $0.00(0.00)$ & $0.00(0.00)$ & $0.00(0.00)$ & $0.00(0.00)$ & $0.00(0.00)$ \\
\hline Sep-09 & $*$ & $62.6(62.6)$ & $62.6(62.6)$ & $680.3(43.3)$ & $265.5(35.5)$ & $945.8(55.9)$ & $*$ & $0.00(0.00)$ & $0.00(0.00)$ & $0.00(0.00)$ & $0.00(0.00)$ & $0.00(0.00)$ \\
\hline Oct-09 & $104.6(104.6)$ & $69.5(15.0)$ & $174.1(105.6)$ & $104.6(44.7)$ & $69.5(82.2)$ & $174.1(93.5)$ & $0.00(0.00)$ & $24(8.00)$ & $24(8.00)$ & $0.00(0.00)$ & 30.4 (17.6) & $30.4(17.6)$ \\
\hline
\end{tabular}


Table 7. Total fishing effort and total catch for bank anglers estimated with angler survey data from Summersville Reservoir, WV. Standard errors are given in parentheses. An asterisk $\left(^{*}\right)$ indicates that no anglers were encountered during the survey period.

\begin{tabular}{|c|c|c|c|c|c|c|c|c|c|c|c|c|}
\hline \multirow[b]{3}{*}{ Month/yr } & \multicolumn{6}{|c|}{ Bank Angler Effort (hours) } & \multicolumn{6}{|c|}{ Bank Angler Catch } \\
\hline & \multicolumn{3}{|c|}{ Walleye anglers } & \multicolumn{3}{|c|}{ All anglers } & \multicolumn{3}{|c|}{ Walleye anglers } & \multicolumn{3}{|c|}{ All anglers } \\
\hline & Weekday & Weekend & Total & Weekday & Weekend & Total & Weekday & Weekend & Total & Weekday & Weekend & Total \\
\hline Dec-08 & $*$ & $*$ & $*$ & $21(26.4)$ & $25.3(25.3)$ & $46.3(36.6)$ & $*$ & $*$ & $*$ & $0.00(0.00)$ & $0.00(0.00)$ & $0.00(0.00)$ \\
\hline Jan-09 & $*$ & $16.8(1.9)$ & $16.8(1.9)$ & * & $16.8(1.9)$ & $16.8(1.9)$ & * & $3.4(3.4)$ & $3.4(3.4)$ & * & $3.4(3.4)$ & $3.4(3.4)$ \\
\hline Feb-09 & $*$ & $*$ & $*$ & $*$ & $*$ & $*$ & $*$ & $*$ & $*$ & $*$ & $*$ & $*$ \\
\hline Mar-09 & $67.3(62.1)$ & $13.5(7.8)$ & $80.8(62.7)$ & $67.3(62.1)$ & $13.5(7.8)$ & $80.8(62.6)$ & $59.3(1.9)$ & $3.5(8.5)$ & $62.8(75.8)$ & $59.3(1.9)$ & $3.5(8.5)$ & $62.8(8.7)$ \\
\hline Apr-09 & $*$ & $13.5(13.5)$ & $13.5(13.5)$ & $126.3(21)$ & $33.7(13.9)$ & $52.8(25.2)$ & $*$ & $8.3(12.8)$ & $8.3(12.8)$ & $9.7(64.8)$ & $2.2(9.8)$ & $11.9(65.6)$ \\
\hline May-09 & $*$ & $*$ & $*$ & $33.7(19.4)$ & $80.8(50.1)$ & $114.5(53.7)$ & $*$ & * & $*$ & $0.00(0.00)$ & $0.00(0.00)$ & $0.00(0.00)$ \\
\hline Jun-09 & $*$ & $*$ & $*$ & $84.2(53.2)$ & $40.4(17.4)$ & $124.6(56)$ & $*$ & $*$ & $*$ & $0.00(0.00)$ & $0.00(0.00)$ & $0.00(0.00)$ \\
\hline Jul-09 & $0(0.00)$ & $6.7(2.6)$ & $6.7(2.6)$ & $44.9(22.4)$ & $47.1(16.9)$ & $92(26.7)$ & $*$ & $0.00(0.00)$ & $0.00(0.00)$ & $0.00(0.00)$ & $0.05(0.06)$ & $0.05(0.06)$ \\
\hline Sep-09 & $*$ & $*$ & $*$ & $42.1(42.1)$ & $*$ & $42.1(42.1)$ & $*$ & * & $*$ & $0.00(0.00)$ & $*$ & $0.00(0.00)$ \\
\hline Oct-09 & $*$ & * & $*$ & * & $15.3(14.9)$ & $15.3(14.9)$ & $*$ & * & * & * & $0.00(0.00)$ & $0.00(0.00)$ \\
\hline
\end{tabular}


Table 8. Total fishing effort and total catch for all anglers (boat and bank anglers combined) estimated with angler survey data from Summersville Reservoir, WV. Standard errors are given in parentheses. An asterisk (*) indicates that no anglers were encountered during the survey period.

\begin{tabular}{|c|c|c|c|c|c|c|c|c|c|c|c|c|}
\hline \multirow[b]{3}{*}{ Month/yr } & \multicolumn{6}{|c|}{ Combined boat and bank angler effort (hours) } & \multicolumn{6}{|c|}{ Combined boat and bank angler catch } \\
\hline & \multicolumn{3}{|c|}{ Walleye anglers } & \multicolumn{3}{|c|}{ All anglers } & \multicolumn{3}{|c|}{ Walleye anglers } & \multicolumn{3}{|c|}{ All anglers } \\
\hline & Weekday & Weekend & Total & Weekday & Weekend & Total & Weekday & Weekend & Total & Weekday & Weekend & Total \\
\hline Dec-08 & $625(101.1)$ & $103.3(32.1)$ & $240.4(106.1)$ & $766(70.1)$ & $433(115.2)$ & $1199(134.9)$ & $587(98.9)$ & $37.5(22.0)$ & $624.5(101.3)$ & $397.7(54.2)$ & $212.1(68.4)$ & $609.8(87.2)$ \\
\hline Jan-09 & $*$ & $54.6(6.7)$ & $54.6(6.7)$ & * & $129.2(23.8)$ & $129.2(23.8)$ & $*$ & $11(4.2)$ & $11(4.2)$ & * & $5.2(3.2)$ & $18.6(4.6)$ \\
\hline Feb-09 & $259(90.4)$ & * & $259(90.4)$ & $509(536.5)$ & $*$ & $509(536.5)$ & $56.5(20.7)$ & * & $56.5(20.7)$ & $45.5(20.7)$ & $*$ & 45.5 (20.7) \\
\hline Mar-09 & $67.3(62.1)$ & $122.5(59.7)$ & $189.8(86.2)$ & $67.3(62.1)$ & $522.8(17.3)$ & $590.1(65)$ & $59.3(1.9)$ & $3.5(8.5)$ & $62.8(8.7)$ & $59.3(1.9)$ & $123.5(21)$ & $182.8(21.1)$ \\
\hline Apr-09 & $*$ & $106.8(94.3)$ & $106.8(94.3)$ & $236.8(112.5)$ & 730.4 (47.4) & $966.8(122)$ & $*$ & $8.3(12.8)$ & $8.3(12.8)$ & $9.7(64.8)$ & $2.2(9.8)$ & 11.9 (65.6) \\
\hline May-09 & $68.2(11.3)$ & $122.2(113.3)$ & $190.4(113.8)$ & $703.5(64)$ & $1440.6(77.7)$ & $2144.1(100.6)$ & $15.2(2.5)$ & $0.00(0.00)$ & $15.2(2.5)$ & $13.5(4.20)$ & $0.00(0.00)$ & $13.5(4.20)$ \\
\hline Jun-09 & $281.2(281.2)$ & $147.3(35.9)$ & $428.5(283.5)$ & $649.8(100.1)$ & $302.9(39.7)$ & 952.7 (107.6) & $0.00(0.00)$ & $6.1(2.10)$ & $6.1(2.10)$ & $0.00(0.00)$ & $3.5(2.20)$ & $3.5(2.20)$ \\
\hline Jul-09 & $170.5(170.5)$ & $9.7(7.4)$ & $180.2(170.7)$ & $215.4(172)$ & $450(51.4)$ & $665.4(179.5)$ & $0.00(0.00)$ & $0.00(0.00)$ & $0.00(0.00)$ & $0.00(0.00)$ & $0.5(0.06)$ & $0.5(0.06)$ \\
\hline Sep-09 & $*$ & $62.6(62.6)$ & $62.6(62.6)$ & $722.4(60.4)$ & $265.5(35.5)$ & $987.9(70.1)$ & $*$ & $0.00(0.00)$ & $0.00(0.00)$ & $0.00(0.00)$ & $0.00(0.00)$ & $0.00(0.00)$ \\
\hline Oct-09 & $104.6(104.6)$ & $69.5(15.0)$ & $174.1(105.6)$ & 273.5 (44.7) & 767.1 (83.6) & $1040.6(93.7)$ & $0.00(0.00)$ & $24.0(8.00)$ & $24.0(8.00)$ & $0.00(0.00)$ & 30.4 (17.6) & 30.4 (17.6) \\
\hline
\end{tabular}


Table 9. Comparison of walleye catch and harvest rates for all anglers (boat anglers, bank anglers, weekday and weekend combined) for two West Virginia reservoirs. An asterisk $(*)$ indicates no available information.

\begin{tabular}{|c|c|c|c|c|c|c|c|}
\hline Author(s) of study & Reservoir & Months sampled & Total effort hours (E) & $\begin{array}{l}\text { Walleye } \\
\text { catch }(\mathrm{C})\end{array}$ & $\begin{array}{c}\text { Walleye } \\
\text { harvest }(\mathrm{H})\end{array}$ & $\mathrm{C} / \mathrm{E}$ & $\mathrm{H} / \mathrm{E}$ \\
\hline Ramsey and Pierce (1981) & Summersville & Apr-June 1980 & 60459 & 476 & 412 & 0.008 & 0.007 \\
\hline Wichterman (this thesis) & Summersville & Apr-June 2009 & 4064 & 29 & 1 & 0.007 & 0.000 \\
\hline Shingleton (1992) & Summersville & Apr-Oct 1990 & 36991 & 359 & 238 & 0.010 & 0.006 \\
\hline Shingleton (1992) & Summersville & Apr-Oct 1991 & 35810 & 643 & 523 & 0.018 & 0.015 \\
\hline Shingleton (1993) & Summersville & Apr-Oct 1992 & 32555 & 593 & 517 & 0.018 & 0.016 \\
\hline Wichterman (this thesis) & Summersville & Apr-Oct 2009 & 6758 & 60 & 2 & 0.009 & 0.000 \\
\hline Shingleton(1992) & Summersville & Nov-Mar 1991 & 4167 & 241 & 185 & 0.058 & 0.044 \\
\hline Shingleton (1993) & Summersville & Nov-Mar 1992 & 5671 & 841 & 520 & 0.148 & 0.092 \\
\hline Wichterman (this thesis) & Summersville & Dec 2008-Mar 2009 & 2427 & 857 & 661 & 0.353 & 0.272 \\
\hline Jernejcic (1986) & Tygart & Mar-July & 20,370 & 2051 & $*$ & 0.101 & $*$ \\
\hline Wichterman (this thesis) & Summersville & Mar-July & 5,319 & 212 & 80 & 0.040 & 0.015 \\
\hline
\end{tabular}


Table 10. Expanded effort (hours) estimated from the number of parked vehicles (which also included an unknown proportion of vehicles associated with non-angling activities). The months of August and November were not sampled.

\begin{tabular}{lcccccc}
\hline & \multicolumn{5}{c}{ Effort (angler hours) } \\
\cline { 2 - 7 } Month & Weekday & SE & Weekend & SE & Total & SE \\
\hline January & 25.3 & 15.1 & 30.3 & 23.3 & 55.6 & 27.8 \\
February & 404.0 & 175.0 & 0.00 & 0.00 & 404.0 & 175.0 \\
March & 1230.3 & 160.5 & 1036.0 & 151.7 & 2266.3 & 220.8 \\
April & 3845.2 & 890.9 & 6922.0 & 1485.3 & 10767.7 & 1732.0 \\
May & 8508.0 & 1135.0 & 21205.3 & 2171.5 & 29713.4 & 2450.2 \\
June & 13471.1 & 2291.6 & 8506.9 & 536.8 & 21978.0 & 2353.6 \\
July & 4130.2 & 681.2 & 3149.3 & 998.5 & 7279.5 & 1208.8 \\
September & 3077.7 & 578.7 & 1313.1 & 89.6 & 4390.8 & 585.6 \\
October & 1708.8 & 275.4 & 2940.1 & 1182.4 & 4648.9 & 1214.1 \\
December & 854.7 & 191.9 & 307.7 & 23.0 & 1162.4 & 193.3 \\
\hline
\end{tabular}


Appendix A. Core and additional questions of the angler and creel survey at Summersville Reservoir.

\section{SUMMERSVILLE RESERVOIR ANGLER SURVEY CORE QUESTIONS}

1. WHAT IS YOUR ZIP CODE ? Use 5 digit Zip Codes. This is helpful when determining where anglers live and how far they are willing to travel to fish.

2. WHEN DID YOU START FISHING TODAY ? Only anglers fishing more than 30 minutes should be interviewed. If the angler has been fishing less than 30 minutes, contact later. Record in 24-hour clock

3. HOW MANY ARE FISHING IN YOUR GROUP TODAY ? If several anglers are present in a boat or on shore, use a separate angler interview form for each angler. If the fish are combined (i.e., not on separate stringers), use one angler interview form for all anglers in the group.

4. WHAT FISH SPECIES ARE YOU TRYING TO CATCH TODAY ?

Suggested Directed Effort Groups

$\underline{\text { Any Species }}$ Walleye Black Bass Crappie $\underline{\text { Sunfish }}$

5. HOW MANY FISH HAVE YOU (OR YOUR GROUP) CAUGHT AND KEPT TODAY? Ask this question exactly as written. If they have not caught and kept any fish, record the name of the species sought and caught as 0 .

a. May I See Them ? Identify and count all fish.

b. May I Measure Them ? Measure all walleye. Record the total length to the nearest millimeter.

6. HOW MANY FISH HAVE YOU (OR YOUR GROUP) CAUGHT AND RELEASED TODAY?

a. Ask Angler Approximate Length Of Released Walleye ?

7. HOW OFTEN DO YOU FISH SUMMERSVILLE RESERVOIR FOR WALLEYE ?

8. ON A SCALE OF 1 TO 9, WHERE 1 MEANS EXTREMELY DISSATISFIED AND 9 MEANS EXTREMELY SATISFIED, HOW SATISFIED ARE YOU WITH TODAY'S FISHING TRIP AT THE SUMMERSVILLE RESERVOIR.

9. WHAT WARMWATER FISH SPECIES DID YOU FISH FOR MOST OFTEN IN WEST VIRGINIA? RANK $\underline{1}$ AS MOST OFTEN, TO $\underline{6}$ LEAST OFTEN.

$\begin{array}{llll}\text { Black Bass } \_ & \text {Catfish } \_ & \text {Sunfish } \\ \text { Walleye } & \text { Musky } \_ & \text {Hybrid STB } & \text { Crappie } \\ \text { Any }\end{array}$

10. HAVE YOU BEEN INTERVIEWED BEFORE DURING THIS FISHING SEASON AT SUMMERSVILLE RESERVOIR?

a. If the response is $\underline{\mathbf{Y E S}}$, interview is complete.

b. If the response is $\underline{\mathbf{N O}}$, ask additional questions 


\section{ADDITIONAL QUESTIONS}

(if answer to \#10 is NO)

1. ON AN AVERAGE FISHING TRIP TO SUMMERSVILLE RESERVOIR,

a. What Percent Of All Walleye You Catch Do You Keep:

b. What Percent Of Walleye You Catch Are Greater Than 15 Inches:

c. What Percent Of Walleye Greater than 15-inches You Catch Do You Keep:

2. WHAT LENGTH WOULD YOU CONSIDER A

"Keepable" Walleye:

“Trophy" Walleye:

3. IN THE LAST 5-YEARS, WOULD YOU CONSIDER

a. Overall WALLEYE fishing at Summersville Reservoir has Improved__ Stayed The Same:__ Got Worst: Don't Know:

b. The size of WALLEYE at Summersville Reservoir has Improved Stayed The Same: Got Worst: Don't Know:

4. THE WVDNR IS CONSIDERING FISHING REGULATIONS CHANGES FOR WALLEYE AT SUMMERSVILLE RESERVOIR.

WHAT IS YOUR OPINION OF THESE POTENTIAL CHANGES

\begin{tabular}{|c|c|c|c|}
\hline Size Limit: & Support & Oppose & Do not care \\
\hline Bag Limit: & Support & Oppose & Do not care \\
\hline Both: & Support & Oppose & Do not care \\
\hline
\end{tabular}

5. DO YOU FISH OTHER WEST VIRGINIA WATERS FOR WALLEYE

Rivers:

Reservoirs:

\section{ADDITIONAL INFORMATION WHICH MUST BE RECORDED IUST PRIOR TO IN TERVIEW:}

1. Is This A Completed Trip (i.e. Leaving Reservoir)

2. Was Angler Group Boat Or Bank Fishers

3. Exact Time Of Interview: 24-HOUR CLOCK

4. Location Of Interview: By Reservoir Code

\section{ADDITIONAL INFORMATION WHICH MUST BE RECORDED} AT START OF DAY :

1. Date

2. Weather Conditions

3. Water Conditions

4. Surface Water Temperature

\section{INFORMATION TO BE COLLECTEDTO DETERMINE OVERALL EFFORT 3 TIMES PER SAMPLE PERIOD}

1. Number Of Vehicles At Each Parking Lot

2. Number Of Bank Anglers At Each Access Point

3. Time of information collected 
Appendix B. Data collected prior to each angler survey at Summersville Reservoir.

\begin{tabular}{|c|c|c|c|c|c|c|}
\hline $\begin{array}{l}\text { Survey } \\
\text { Number }\end{array}$ & $\begin{array}{c}\text { Survey } \\
\text { Day }\end{array}$ & Date & $\begin{array}{l}\text { Completed } \\
\text { trip }(\mathrm{Y} / \mathrm{N})\end{array}$ & $\begin{array}{l}\text { Angler } \\
\text { Type }\end{array}$ & $\begin{array}{c}\text { Interview } \\
\text { Time }\end{array}$ & $\begin{array}{l}\text { Interview } \\
\text { Location }\end{array}$ \\
\hline 1 & 1 & 28-Nov & $\mathrm{Y}$ & boat & $13: 15$ & Long Point \\
\hline 2 & 1 & 28-Nov & $\mathrm{N}$ & boat & $16: 00$ & Salmon Run \\
\hline 3 & 1 & 28-Nov & $\mathrm{Y}$ & boat & $16: 30$ & Long Point \\
\hline 4 & 1 & 28-Nov & $\mathrm{Y}$ & boat & $16: 35$ & Long Point \\
\hline 5 & 1 & 28-Nov & $\mathrm{Y}$ & boat & $17: 00$ & Long Point \\
\hline 6 & 4 & 6-Dec & $\mathrm{Y}$ & boat & $16: 42$ & Winter Ramp \\
\hline 7 & 6 & 13-Dec & $\mathrm{Y}$ & boat & $16: 00$ & Winter Ramp \\
\hline 8 & 6 & 13-Dec & $\mathrm{Y}$ & boat & $16: 20$ & Winter Ramp \\
\hline 9 & 6 & 13-Dec & $\mathrm{Y}$ & boat & $16: 30$ & Winter Ramp \\
\hline 10 & 6 & 13-Dec & $\mathrm{N}$ & bank & $17: 00$ & Winter Ramp \\
\hline 11 & 8 & 20-Dec & $\mathrm{N}$ & boat & $12: 15$ & Salmon Run \\
\hline 12 & 8 & 20-Dec & $\mathrm{Y}$ & boat & $16: 20$ & Salmon Run \\
\hline 13 & 8 & 20-Dec & $\mathrm{Y}$ & boat & $16: 56$ & Salmon Run \\
\hline 14 & 10 & 3-Jan & $\mathrm{Y}$ & boat & $12: 10$ & Winter Ramp \\
\hline 15 & 10 & 3-Jan & $\mathrm{Y}$ & bank & $14: 30$ & Winter Ramp \\
\hline 16 & 25 & 26-Feb & $\mathrm{Y}$ & boat & $11: 43$ & Winter Ramp \\
\hline 17 & 25 & 26-Feb & $\mathrm{Y}$ & Boat & $15: 15$ & Winter Ramp \\
\hline 18 & 25 & 26-Feb & $\mathrm{Y}$ & boat & $15: 20$ & Winter Ramp \\
\hline 19 & 30 & 14-Mar & $\mathrm{y}$ & boat & $14: 00$ & Winter Ramp \\
\hline 20 & 30 & 14-Mar & $\mathrm{n}$ & bank & $15: 05$ & Brocks Bridge \\
\hline 21 & 31 & 17-Mar & $\mathrm{n}$ & bank & $13: 10$ & Brocks Bridge \\
\hline 22 & 31 & 17-Mar & $\mathrm{n}$ & bank & $11: 30$ & Brocks Bridge \\
\hline 23 & 32 & 22-Mar & $\mathrm{y}$ & boat & $12: 51$ & Winter Ramp \\
\hline 24 & 32 & 22-Mar & $\mathrm{y}$ & bank & $15: 30$ & Brocks Bridge \\
\hline 25 & 32 & 22-Mar & $\mathrm{y}$ & boat & $13: 50$ & Salmon Run \\
\hline 26 & 32 & 22-Mar & $\mathrm{y}$ & boat & $16: 15$ & Salmon Run \\
\hline 27 & 32 & 22-Mar & $\mathrm{y}$ & boat & $17: 15$ & Winter Ramp \\
\hline 28 & 32 & 22-Mar & $\mathrm{y}$ & boat & $17: 30$ & Winter Ramp \\
\hline 29 & 34 & 28-Mar & $\mathrm{n}$ & bank & $14: 12$ & Brocks Bridge \\
\hline 30 & 34 & 28-Mar & $\mathrm{y}$ & boat & $16: 20$ & Winter Ramp \\
\hline 31 & 34 & 28-Mar & $\mathrm{y}$ & boat & $16: 30$ & Winter Ramp \\
\hline 32 & 35 & 5-Apr & $\mathrm{n}$ & bank & $12: 45$ & Brocks Bridge \\
\hline 33 & 36 & 5-Apr & $\mathrm{n}$ & bank & $9: 25$ & Salmon Run \\
\hline 34 & 38 & 11-Apr & $\mathrm{y}$ & boat & $9: 00$ & Battle Run \\
\hline 35 & 38 & 11-Apr & $\mathrm{y}$ & boat & $14: 08$ & Long Point \\
\hline 36 & 38 & 11-Apr & $\mathrm{y}$ & boat & $14: 16$ & Long Point \\
\hline 37 & 38 & 11-Apr & $\mathrm{y}$ & boat & $14: 28$ & Long Point \\
\hline 38 & 38 & 11-Apr & $\mathrm{y}$ & boat & $14: 32$ & Long Point \\
\hline 39 & 39 & 17-Apr & $\mathrm{n}$ & bank & $12: 47$ & Battle Run \\
\hline
\end{tabular}




\begin{tabular}{|c|c|c|c|c|c|c|}
\hline 40 & 39 & 17-Apr & $\mathrm{y}$ & boat & $12: 50$ & Battle Run \\
\hline 41 & 39 & 17-Apr & $\mathrm{n}$ & bank & $14: 30$ & Salmon Run \\
\hline 42 & 39 & 17-Apr & $\mathrm{n}$ & bank & $14: 35$ & Salmon Run \\
\hline 43 & 40 & 18-Apr & $\mathrm{y}$ & boat & $13: 50$ & Salmon Run \\
\hline 44 & 40 & 18-Apr & $\mathrm{y}$ & boat & $14: 27$ & Salmon Run \\
\hline 45 & 40 & 18-Apr & $\mathrm{y}$ & boat & $16: 10$ & Salmon Run \\
\hline 46 & 40 & 18-Apr & $\mathrm{n}$ & bank & $16: 20$ & Salmon Run \\
\hline 47 & 41 & 20-Apr & $\mathrm{n}$ & bank & $12: 00$ & Battle Run \\
\hline 48 & 41 & 20-Apr & $\mathrm{n}$ & bank & $12: 10$ & Battle Run \\
\hline 49 & 42 & 26-Apr & $\mathrm{y}$ & boat & $10: 15$ & Salmon Run \\
\hline 50 & 42 & 26-Apr & $\mathrm{n}$ & boat & $10: 20$ & Salmon Run \\
\hline 51 & 42 & 26-Apr & $\mathrm{y}$ & boat & 13:00 & Battle Run \\
\hline 52 & 42 & 26-Apr & $\mathrm{y}$ & boat & 13:05 & Battle Run \\
\hline 53 & 42 & 26-Apr & $\mathrm{n}$ & bank & $13: 45$ & Salmon Run \\
\hline 54 & 42 & 26-Apr & $\mathrm{n}$ & bank & $14: 00$ & Salmon Run \\
\hline 55 & 43 & 27-Apr & $\mathrm{Y}$ & bank & $14: 13$ & Battle Run \\
\hline 56 & 43 & 27-Apr & $\mathrm{n}$ & bank & $15: 22$ & Salmon Run \\
\hline 57 & 43 & 27-Apr & $\mathrm{y}$ & boat & $15: 45$ & Salmon Run \\
\hline 58 & 44 & 3-May & $\mathrm{n}$ & bank & $9: 30$ & Salmon Run \\
\hline 59 & 44 & 3-May & $\mathrm{y}$ & boat & $13: 03$ & Long Point \\
\hline 60 & 44 & 3-May & $\mathrm{y}$ & boat & $13: 40$ & Battle Run \\
\hline 61 & 44 & 3-May & $\mathrm{y}$ & boat & $16: 10$ & Battle Run \\
\hline 62 & 44 & 3-May & $\mathrm{y}$ & boat & $16: 20$ & Battle Run \\
\hline 63 & 44 & 3-May & $\mathrm{y}$ & boat & $17: 20$ & Salmon Run \\
\hline 64 & 45 & 7-May & $\mathrm{y}$ & boat & $14: 32$ & Battle Run \\
\hline 65 & 45 & 7-May & $\mathrm{y}$ & boat & $9: 36$ & Battle Run \\
\hline 66 & 45 & 7-May & $\mathrm{y}$ & boat & $12: 31$ & Long Point \\
\hline 67 & 46 & 10-May & $\mathrm{y}$ & boat & $10: 33$ & Salmon Run \\
\hline 68 & 46 & 10-May & $\mathrm{y}$ & boat & $11: 40$ & Battle Run \\
\hline 69 & 46 & 10-May & $\mathrm{y}$ & boat & $13: 50$ & Long Point \\
\hline 70 & 46 & 10-May & $\mathrm{y}$ & boat & $14: 00$ & Long Point \\
\hline 71 & 46 & 10-May & $\mathrm{y}$ & boat & $15: 52$ & Salmon Run \\
\hline 72 & 47 & 11-May & $\mathrm{y}$ & boat & $8: 40$ & Salmon Run \\
\hline 73 & 47 & 11-May & $\mathrm{y}$ & boat & $12: 02$ & Salmon Run \\
\hline 74 & 47 & 11-May & $\mathrm{n}$ & bank & $13: 42$ & Battle Run \\
\hline 75 & 48 & 16-May & $\mathrm{n}$ & boat & $9: 54$ & Salmon Run \\
\hline 76 & 48 & 16-May & $\mathrm{y}$ & boat & $10: 30$ & Battle Run \\
\hline 77 & 48 & 16-May & $\mathrm{y}$ & boat & $11: 46$ & Battle Run \\
\hline 78 & 48 & 16-May & $\mathrm{y}$ & boat & $13: 25$ & Salmon Run \\
\hline 79 & 48 & 16-May & $\mathrm{y}$ & boat & $13: 35$ & Salmon Run \\
\hline 80 & 48 & 16-May & $\mathrm{y}$ & boat & $15: 41$ & Battle Run \\
\hline 81 & 48 & 16-May & $\mathrm{y}$ & boat & $16: 02$ & Battle Run \\
\hline 82 & 48 & 16-Мay & $\mathrm{n}$ & bank & $16: 23$ & Battle Run \\
\hline
\end{tabular}




\begin{tabular}{|c|c|c|c|c|c|c|}
\hline 83 & 49 & 21-May & $\mathrm{y}$ & boat & $10: 30$ & Salmon Run \\
\hline 84 & 49 & 21-May & y & boat & $12: 30$ & Battle Run \\
\hline 85 & 49 & 21-May & Y & bank & $15: 30$ & Salmon Run \\
\hline 86 & 50 & 24-May & Y & boat & $9: 30$ & Salmon Run \\
\hline 87 & 50 & 24-May & y & boat & 10:17 & Long Point \\
\hline 88 & 50 & 24-May & $\mathrm{n}$ & boat & $10: 35$ & Long Point \\
\hline 89 & 50 & 24-May & $\mathrm{n}$ & boat & 11:00 & Long Point \\
\hline 90 & 50 & 24-May & $\mathrm{y}$ & bank & $12: 25$ & Battle Run \\
\hline 91 & 50 & 24-May & $\mathrm{y}$ & bank & $12: 31$ & Battle Run \\
\hline 92 & 50 & 24-May & $\mathrm{n}$ & bank & $13: 38$ & Salmon Run \\
\hline 93 & 50 & 24-May & $\mathrm{y}$ & boat & 14:00 & Salmon Run \\
\hline 94 & 50 & 24-May & $\mathrm{y}$ & boat & $15: 03$ & Long Point \\
\hline 95 & 50 & 24-May & $\mathrm{n}$ & bank & $16: 22$ & Battle Run \\
\hline 96 & 52 & 31-May & $\mathrm{n}$ & bank & 13:00 & Salmon Run \\
\hline 97 & 52 & 31-May & $\mathrm{n}$ & bank & $14: 40$ & Salmon Run \\
\hline 98 & 52 & 31-May & $\mathrm{n}$ & bank & $15: 36$ & Salmon Run \\
\hline 99 & 52 & 31-May & $\mathrm{y}$ & boat & 17:09 & Salmon Run \\
\hline 100 & 52 & 31-May & $\mathrm{y}$ & boat & 18:04 & Long Point \\
\hline 101 & 52 & 31-May & $\mathrm{n}$ & boat & 18:00 & Long Point \\
\hline 102 & 52 & 31-May & $\mathrm{n}$ & bank & 18:56 & Battle Run \\
\hline 103 & 53 & 3-Jun & $\mathrm{y}$ & boat & $14: 15$ & Battle Run \\
\hline 104 & 54 & 7-Jun & $\mathrm{y}$ & boat & $10: 47$ & Salmon Run \\
\hline 105 & 54 & 7-Jun & y & bank & $14: 15$ & Battle Run \\
\hline 106 & 54 & 7-Jun & $\mathrm{y}$ & boat & 18:00 & Salmon Run \\
\hline 107 & 55 & 12-Jun & $\mathrm{y}$ & boat & $9: 38$ & Salmon Run \\
\hline 108 & 55 & 12-Jun & $\mathrm{n}$ & bank & $14: 20$ & Salmon Run \\
\hline 109 & 55 & 12-Jun & $\mathrm{n}$ & bank & $15: 14$ & Salmon Run \\
\hline 110 & 55 & 12-Jun & $\mathrm{n}$ & bank & $15: 18$ & Salmon Run \\
\hline 111 & 56 & 14-Jun & $\mathrm{n}$ & bank & $12: 23$ & Salmon Run \\
\hline 112 & 56 & 14-Jun & $\mathrm{y}$ & boat & $13: 43$ & Battle Run \\
\hline 113 & 56 & 14-Jun & $\mathrm{n}$ & bank & $15: 48$ & Salmon Run \\
\hline 114 & 56 & 14-Jun & $\mathrm{n}$ & bank & $16: 00$ & Salmon Run \\
\hline 115 & 56 & 14-Jun & $\mathrm{n}$ & boat & $17: 03$ & Long Point \\
\hline 116 & 57 & 18-Jun & $\mathrm{y}$ & bank & $11: 17$ & Battle Run \\
\hline 117 & 57 & 18-Jun & y & bank & $16: 22$ & Battle Run \\
\hline 118 & 58 & 20-Jun & y & boat & 11:02 & Battle Run \\
\hline 119 & 58 & 20-Jun & $\mathrm{n}$ & boat & $17: 29$ & Long Point \\
\hline 120 & 58 & 20-Jun & $\mathrm{n}$ & boat & $17: 43$ & Battle Run \\
\hline 121 & 59 & 24-Jun & $\mathrm{y}$ & boat & $16: 17$ & Salmon Run \\
\hline 122 & 60 & 28-Jun & y & boat & $12: 01$ & Battle Run \\
\hline 123 & 60 & 28-Jun & $\mathrm{n}$ & bank & 16:09 & Salmon Run \\
\hline 124 & 60 & 28-Jun & $\mathrm{y}$ & bank & $16: 22$ & Salmon Run \\
\hline 125 & 62 & 5-Jul & $\mathrm{y}$ & bank & $8: 10$ & Salmon Run \\
\hline
\end{tabular}




\begin{tabular}{|c|c|c|c|c|c|c|}
\hline 126 & 62 & 5-Jul & $\mathrm{y}$ & boat & 17:00 & Battle Run \\
\hline 127 & 62 & 5-Jul & $\mathrm{n}$ & bank & $17: 17$ & Battle Run \\
\hline 128 & 62 & 5-Jul & $\mathrm{y}$ & bank & $17: 43$ & Battle Run \\
\hline 129 & 63 & 10-Jul & $\mathrm{y}$ & boat & $10: 43$ & Salmon Run \\
\hline 130 & 63 & 10-Jul & $\mathrm{y}$ & bank & $12: 00$ & Battle Run \\
\hline 131 & 64 & 11-Jul & $\mathrm{y}$ & boat & $9: 30$ & Salmon Run \\
\hline 132 & 65 & 15-Jul & $\mathrm{y}$ & bank & $17: 30$ & Battle Run \\
\hline 133 & 66 & 18-Jul & $\mathrm{y}$ & boat & $10: 25$ & Long Point \\
\hline 134 & 66 & 18-Jul & $\mathrm{N}$ & boat & $15: 00$ & Long Point \\
\hline 135 & 66 & 18-Jul & $\mathrm{y}$ & boat & $15: 04$ & Long Point \\
\hline 136 & 66 & 18-Jul & $\mathrm{n}$ & bank & $15: 50$ & Salmon Run \\
\hline 137 & 66 & 18-Jul & $\mathrm{n}$ & bank & $17: 29$ & Battle Run \\
\hline 138 & 68 & 24-Jul & $\mathrm{n}$ & bank & $9: 45$ & Salmon Run \\
\hline 139 & 68 & 24-Jul & $\mathrm{n}$ & bank & $16: 50$ & Battle Run \\
\hline 140 & 69 & 9-Sep & $\mathrm{n}$ & bank & $12: 25$ & Salmon Run \\
\hline 141 & 69 & 9-Sep & $\mathrm{n}$ & bank & $16: 52$ & Battle Run \\
\hline 142 & 71 & 15-Sep & $\mathrm{y}$ & boat & $12: 53$ & Battle Run \\
\hline 143 & 71 & 15-Sep & $\mathrm{y}$ & boat & 13:00 & Battle Run \\
\hline 144 & 71 & 15-Sep & $\mathrm{y}$ & boat & $15: 20$ & Salmon Run \\
\hline 145 & 72 & 19-Sep & $\mathrm{y}$ & boat & $14: 32$ & Long Point \\
\hline 146 & 72 & 19-Sep & $\mathrm{y}$ & boat & $17: 02$ & Battle Run \\
\hline 147 & 74 & 27-Sep & $\mathrm{n}$ & boat & $10: 22$ & Battle Run \\
\hline 148 & 76 & 3-Oct & $\mathrm{n}$ & boat & 11:04 & Battle Run \\
\hline 149 & 76 & 3-Oct & $\mathrm{y}$ & boat & $15: 00$ & Long Point \\
\hline 150 & 76 & 3-Oct & $\mathrm{y}$ & boat & $16: 03$ & Salmon Run \\
\hline 151 & 78 & $10-\mathrm{Oct}$ & $\mathrm{y}$ & boat & $14: 40$ & Long Point \\
\hline 152 & 78 & $10-$ Oct & $\mathrm{y}$ & boat & $17: 40$ & Battle Run \\
\hline 153 & 79 & $14-\mathrm{Oct}$ & $\mathrm{y}$ & boat & $16: 41$ & Long Point \\
\hline 154 & 80 & 18 -Oct & $\mathrm{y}$ & boat & $14: 28$ & Long Point \\
\hline 155 & 80 & $18-\mathrm{Oct}$ & $\mathrm{y}$ & boat & $14: 45$ & Long Point \\
\hline 156 & 80 & $18-\mathrm{Oct}$ & $\mathrm{y}$ & boat & $15: 00$ & Long Point \\
\hline 157 & 80 & $18-\mathrm{Oct}$ & $\mathrm{y}$ & Boat & $15: 11$ & Long Point \\
\hline 158 & 80 & $18-\mathrm{Oct}$ & $\mathrm{y}$ & Boat & $15: 20$ & Long Point \\
\hline 159 & 81 & 22-Oct & $\mathrm{y}$ & Boat & $11: 27$ & Winter Ramp \\
\hline 160 & 81 & 22-Oct & $\mathrm{y}$ & Boat & $12: 30$ & Long Point \\
\hline 161 & 82 & $25-\mathrm{Oct}$ & $\mathrm{y}$ & Boat & 11:02 & Salmon Run \\
\hline 162 & 82 & $25-\mathrm{Oct}$ & $\mathrm{y}$ & Boat & $15: 53$ & Long Point \\
\hline 163 & 82 & $25-\mathrm{Oct}$ & $\mathrm{y}$ & Boat & $15: 59$ & Long Point \\
\hline 164 & 84 & $31-$ Oct & $\mathrm{n}$ & Bank & $16: 45$ & Long Point \\
\hline 165 & 84 & 31-Oct & $\mathrm{y}$ & Boat & $17: 24$ & Long Point \\
\hline
\end{tabular}


Appendix C. Daily weather and water conditions for angler surveys on Summersville Reservoir $(\mathrm{NM}=$ water temperature not measured $)$.

\begin{tabular}{|c|c|c|c|c|}
\hline $\begin{array}{c}\text { Survey } \\
\text { day } \\
\text { Number }\end{array}$ & Sample & Weather conditions & conditions & $\begin{array}{l}\text { Water } \\
\text { temp } \\
\left({ }^{\circ} \mathrm{C}\right) \\
\end{array}$ \\
\hline 1 & 28-Nov-08 & Clear and Sunny, 7 & Clear & 9 \\
\hline 2 & 29-Nov-08 & Rain, overcast, 8 & Clear & 9 \\
\hline 3 & 1-Dec-08 & Snow, overcast, 1.7 & Stained & 9.5 \\
\hline 4 & 6-Dec-08 & Overcast, 1.7 & Clear & 7.8 \\
\hline 5 & 10-Dec-08 & Rain, 7.2 & Clear & 7.5 \\
\hline 6 & 14-Dec-08 & Clear, 7.2 & Turbid & 7 \\
\hline 7 & 19-Dec-08 & Rain, 14.3 & Turbid & 8.5 \\
\hline 8 & 20-Dec-08 & Overcast, 6.2 & Turbid & 6.2 \\
\hline 9 & 1-Jan-09 & Clear, 2.8 & Clear & 5 \\
\hline 10 & 3-Jan-09 & Clear, 8.3 & Clear & 4.8 \\
\hline 11 & 8-Jan-09 & Rain, 8.3 & Turbid & 4.6 \\
\hline 12 & 10-Jan-09 & Rain, 8.3 & Turbid & 5.2 \\
\hline 13 & 14-Jan-09 & Overcast, -2.8 & Turbid & 4.8 \\
\hline 14 & 17-Jan-09 & Clear, 1.7 & Frozen & NM \\
\hline 15 & 19-Jan-09 & Snow, -3.9 & Frozen & NM \\
\hline 16 & 24-Jan-09 & Snow, 7.2 & Frozen & NM \\
\hline 17 & 26-Jan-09 & Overcast, - 2.8 & Frozen & NM \\
\hline 18 & 1-Feb-09 & Clear, 12.8 & Frozen & NM \\
\hline 19 & 5-Feb-09 & Snow, - 9.4 & Frozen & NM \\
\hline 20 & 8-Feb-09 & Clear, 12.8 & Frozen & NM \\
\hline 21 & 10-Feb-09 & Rain/Sleet, 12.8 & Frozen & NM \\
\hline 22 & 15-Feb-09 & Clear, 1.7 & Clear & 4 \\
\hline 23 & 20-Feb-09 & Clear, -3.9 & Clear & 4.4 \\
\hline 24 & 21-Feb-09 & Clear, -3.9 & Clear & 3.2 \\
\hline 25 & 26-Feb-09 & Overcast, 5 & Clear & 2.5 \\
\hline 26 & 1-Mar-09 & Clear, -3.9 & Clear & 2.4 \\
\hline 27 & 2-Mar-09 & Clear, 7.2 & Clear & 4.8 \\
\hline 28 & 7-Mar-09 & Clear, 18.3 & Clear & 5.5 \\
\hline 29 & 10-Mar-09 & Clear, 12.8 & Clear & 5.8 \\
\hline 30 & 14-Mar-09 & Rain, 6 & Clear & 6.8 \\
\hline 31 & 17-Mar-09 & Partly Cloudy, 16 & Turbid & 5.8 \\
\hline 32 & 22-Mar-09 & Clear, 18.3 & Clear & 12 \\
\hline 33 & 27-Mar-09 & Overcast, 14 & Clear & 11.5 \\
\hline 34 & 28-Mar-09 & Overcast, Rain, 9 & Turbid & 11.3 \\
\hline 35 & 30-Mar-09 & Partly cloudy, 17 & Turbid & 11.4 \\
\hline 36 & 5-Apr-09 & Clear, 23.9 & Stained & 12 \\
\hline
\end{tabular}




\begin{tabular}{|c|c|c|c|c|}
\hline 37 & 6-Apr-09 & Rain, 6 & Stained & 12.2 \\
\hline 38 & 11-Apr-09 & Overcast, 6 & Turbid & 9.7 \\
\hline 39 & 17-Apr-09 & Sunny, 17 & Turbid & 13.8 \\
\hline 40 & 18-Apr-09 & Sunny, 22 & Stained & 14.1 \\
\hline 41 & 20-Apr-09 & Rain, 23.9 & Stained & 23 \\
\hline 42 & 26-Apr-09 & Sunny, 27 & Clear & 24.3 \\
\hline 43 & 27-Apr-09 & Sunny, 33 & Clear & 25.6 \\
\hline 44 & 3-May-09 & Overcast, Rain, 12 & Clear & 23.6 \\
\hline 45 & 7-Мay-09 & Rain, 18.3 & Clear & 22.4 \\
\hline 46 & 10-May-09 & Sunny, 21.4 & Clear & 23.9 \\
\hline 47 & 11-May-09 & Overcast, Drizzle, 23.4 & Clear & 24 \\
\hline 48 & 16-Мay-09 & Sunny, 28 & Clear & 24.5 \\
\hline 49 & 21-May-09 & Sunny, 25 & Clear & 19.3 \\
\hline 50 & 24-May-09 & Sunny, 27.2 & Clear & 25.1 \\
\hline 51 & 26-May-09 & Rain, 20 & Clear & 24.2 \\
\hline 52 & 31-May-09 & Partly Sunny, 23 & Clear & 23.7 \\
\hline 53 & 3-Jun-09 & Sunny, 27 & Clear & 25.3 \\
\hline 54 & 7-Jun-09 & Overcast, 26 & Stained & 23.2 \\
\hline 55 & 12-Jun-09 & Rain, 21 & Clear & 24 \\
\hline 56 & 14-Jun-09 & Sunny, 25 & Clear & 25.3 \\
\hline 57 & 18-Jun-09 & Overcast, 26 & Clear & 25.7 \\
\hline 58 & 20-Jun-09 & Sunny, 27.2 & Clear & 26.2 \\
\hline 59 & 24-Jun-09 & Sunny, 27.9 & Clear & 26.2 \\
\hline 60 & 28-Jun-09 & Sunny, 28 & Clear & 25.8 \\
\hline 61 & 29-Jun-09 & Partly Cloudy & Clear & 25.7 \\
\hline 62 & 5-Jul-09 & Rain, 21 & Stained & 23.3 \\
\hline 63 & 10-Jul-09 & Rain, 26 & Clear & 24.8 \\
\hline 64 & 11-Jul-09 & Sunny, 28.8 & Clear & 25 \\
\hline 65 & 15-Jul-09 & Scattered Thunderstorms, 24 & Clear & 25.5 \\
\hline 66 & 18-Jul-09 & Clear, 21.9 & Clear & 25.9 \\
\hline 67 & 22-Jul-09 & Clear, 30 & Clear & 26.9 \\
\hline 68 & 24-Jul-09 & Rain, 22 & Clear & 26 \\
\hline 69 & 9-Sep-09 & Scattered Thunderstorms, 21 & Clear & 23.2 \\
\hline 70 & 13-Sep-09 & Sunny, 20.0 & Clear & 23.1 \\
\hline 71 & 15-Sep-09 & Partly Cloudy, 23 & Clear & 27.7 \\
\hline 72 & 19-Sep-09 & Sunny, 25 & Clear & 25.1 \\
\hline 73 & 22-Sep-09 & Partly Cloudy, 23. 2 & Clear & 23.7 \\
\hline 74 & 27-Sep-09 & Overcast, Drizzle, 18.3 & clear & 20.1 \\
\hline 75 & 30-Sep-09 & Cloudy, 10 & Stained & 19.2 \\
\hline 76 & 3-Oct-09 & Overcast, 20 & Clear & 18.9 \\
\hline 77 & 9-Oct-09 & Scattered Thunderstorms, 21 & Clear & 19.5 \\
\hline 78 & 10-Oct-09 & Rain, 17.7 & Clear & 19.9 \\
\hline 79 & 14-Oct-09 & Rain, 11.1 & Clear & 19.4 \\
\hline
\end{tabular}




$\begin{array}{llclc}80 & \text { 18-Oct-09 } & \text { Overcast, Windy 8.5 } & \text { Clear } & 17.8 \\ 81 & 22-\text {-Oct-09 } & \text { Partly Cloudy, 19 } & \text { Clear } & 18.4 \\ 82 & 24-\text {-Oct-09 } & \text { Sunny, 15 } & \text { Clear } & 17.8 \\ 83 & 29-\text {-Oct-09 } & \text { Partly Cloudy, 16.6 } & \text { Clear } & 17 \\ 84 & 31 \text {-Oct-09 } & \text { Rain, 12.7 } & \text { Clear } & 16.6 \\ & & & \\ \end{array}$


Appendix D. Counts of vehicles (VC) and bank anglers (BA) from angler surveys at Summersville Reservoir.

\begin{tabular}{|c|c|c|c|c|c|c|c|c|c|}
\hline \multicolumn{10}{|c|}{ Battle Run } \\
\hline \multirow{2}{*}{$\begin{array}{c}\text { Survey } \\
\text { Day }\end{array}$} & \multicolumn{3}{|c|}{ Round 1} & \multicolumn{3}{|c|}{ Round 2} & \multicolumn{3}{|c|}{ Round 3} \\
\hline & time & $\mathrm{VC}$ & BA & time & $\mathrm{VC}$ & BA & time & $\mathrm{VC}$ & BA \\
\hline 38 & $848-930$ & 4 & 0 & $1042-1124$ & 4 & 0 & $1500-1542$ & 1 & 0 \\
\hline 39 & $1030-1112$ & 2 & 0 & $1214-1256$ & 9 & 0 & $1624-1706$ & 4 & 0 \\
\hline 40 & $910-1006$ & 46 & 0 & $1228-1324$ & 52 & 0 & $1651-1747$ & 12 & 0 \\
\hline 41 & $810-906$ & 0 & 1 & $1234-1330$ & 2 & 1 & $1455-1551$ & 2 & 0 \\
\hline 42 & $800-856$ & 11 & 0 & $1223-1319$ & 41 & 0 & $1645-1741$ & 11 & 0 \\
\hline 43 & $811-907$ & 8 & 0 & $1033-1129$ & 3 & 0 & $1353-1449$ & 3 & 1 \\
\hline 44 & $1015-1111$ & 68 & 0 & $1339-1435$ & 77 & 0 & $1600-1656$ & 80 & 0 \\
\hline 45 & $910-1006$ & 8 & 0 & $1333-1429$ & 8 & 0 & $1553-1649$ & 2 & 0 \\
\hline 46 & 911-1007 & 16 & 0 & $1134-1230$ & 28 & 0 & $1655-1751$ & 34 & 0 \\
\hline 47 & $1010-1106$ & 8 & 0 & $1334-1430$ & 7 & 1 & $1656-1752$ & 4 & 0 \\
\hline 48 & 1011-1108 & 60 & 0 & $1108-1204$ & 60 & 0 & $1530-1626$ & 32 & 1 \\
\hline 49 & $911-1007$ & 8 & 0 & $1235-1331$ & 13 & 0 & $1553-1649$ & 5 & 0 \\
\hline 50 & $800-856$ & 70 & 0 & $1220-1316$ & 100 & 2 & $1540-1636$ & 75 & 0 \\
\hline 51 & $912-1008$ & 1 & 0 & $1232-1328$ & 3 & 0 & $1550-1646$ & 3 & 0 \\
\hline 52 & $1210-1306$ & 53 & 0 & $1306-1402$ & 50 & 0 & $1830-1926$ & 20 & 1 \\
\hline 53 & $1111-1207$ & 4 & 0 & $1333-1429$ & 12 & 0 & $1700-1756$ & 4 & 0 \\
\hline 54 & $800-856$ & 10 & 0 & $1326-1422$ & 24 & 1 & $1600-1656$ & 32 & 0 \\
\hline 55 & $1015-1111$ & 10 & 0 & $1111-1207$ & 23 & 0 & $1637-1733$ & 29 & 0 \\
\hline 56 & $912-1008$ & 15 & 0 & $1333-1429$ & 25 & 0 & $1429-1525$ & 41 & 0 \\
\hline 57 & $1015-1112$ & 3 & 0 & $1112-1208$ & 4 & 1 & $1537-1633$ & 4 & 1 \\
\hline 58 & $1015-1111$ & 18 & 0 & $1230-1326$ & 25 & 0 & $1555-1651$ & 30 & 0 \\
\hline 59 & $1014-1110$ & 1 & 0 & $1238-1334$ & 3 & 0 & $1500-1556$ & 8 & 0 \\
\hline 60 & $1014-1110$ & 8 & 0 & $1110-1206$ & 11 & 0 & $1435-1531$ & 24 & 0 \\
\hline 61 & $800-856$ & 4 & 0 & $1225-1321$ & 8 & 0 & $1545-1641$ & 11 & 0 \\
\hline 62 & 911-1007 & 3 & 0 & $1133-1229$ & 5 & 0 & $1656-1752$ & 1 & 2 \\
\hline 63 & 910-1006 & 2 & 0 & $1130-1226$ & 2 & 1 & $1452-1548$ & 6 & 0 \\
\hline 64 & $1014-1110$ & 3 & 0 & $1337-1433$ & 3 & 0 & $1433-1529$ & 7 & 0 \\
\hline 65 & $1015-1111$ & 1 & 0 & $1111-1207$ & 3 & 0 & $1636-1732$ & 2 & 1 \\
\hline 66 & 910-1006 & 9 & 0 & $1330-1426$ & 23 & 0 & $1655-1751$ & 30 & 1 \\
\hline 67 & $800-856$ & 3 & 0 & $1122-1218$ & 2 & 0 & $1600-1656$ & 5 & 0 \\
\hline 68 & $1015-1111$ & 0 & 0 & $1238-1334$ & 1 & 0 & $1604-1700$ & 2 & 1 \\
\hline 69 & $910-1006$ & 2 & 0 & $1330-1426$ & 0 & 0 & $1658-1754$ & 1 & 1 \\
\hline 70 & $1012-1108$ & 1 & 0 & $1235-1331$ & 1 & 0 & $1457-1553$ & 0 & 0 \\
\hline 71 & $910-1006$ & 2 & 0 & $1230-1326$ & 0 & 0 & $1542-1638$ & 1 & 0 \\
\hline 72 & $800-856$ & 1 & 0 & $1123-1219$ & 0 & 0 & $1644-1740$ & 4 & 0 \\
\hline 73 & 910-1006 & 0 & 0 & $1330-1426$ & 0 & 0 & $1642-1738$ & 0 & 0 \\
\hline 74 & $1010-1106$ & 1 & 0 & $1332-1428$ & 2 & 0 & $1652-1748$ & 2 & 0 \\
\hline 75 & 910-1006 & 0 & 0 & $1333-1429$ & 0 & 0 & $1429-1523$ & 0 & 0 \\
\hline 76 & 1011-1107 & 2 & 0 & $1107-1203$ & 2 & 0 & $1630-1726$ & 0 & 0 \\
\hline 77 & $911-1007$ & 1 & 0 & $1337-1433$ & 3 & 0 & $1433-1529$ & 0 & 0 \\
\hline 78 & $800-856$ & 1 & 0 & $1325-1421$ & 0 & 0 & $1648-1744$ & 3 & 0 \\
\hline
\end{tabular}




\begin{tabular}{|c|c|c|c|c|c|c|c|c|c|}
\hline \multicolumn{10}{|c|}{ Brock's Bridge } \\
\hline \multirow{2}{*}{$\begin{array}{c}\text { Survey } \\
\text { Day }\end{array}$} & \multicolumn{3}{|c|}{ Round 1} & \multicolumn{3}{|c|}{ Round 2} & \multicolumn{3}{|c|}{ Round 3} \\
\hline & time & $\mathrm{VC}$ & $\mathrm{BA}$ & time & $\mathrm{VC}$ & $\mathrm{BA}$ & time & $\mathrm{VC}$ & $\mathrm{BA}$ \\
\hline 1 & $1000-1040$ & 0 & 0 & $1330-1410$ & 0 & 0 & & 0 & 0 \\
\hline 2 & $730-826$ & 0 & 0 & $1323-1419$ & 0 & 0 & $1640-1736$ & 0 & 0 \\
\hline 3 & $730-826$ & 0 & 0 & $1205-1301$ & 0 & 0 & $1635-1731$ & 0 & 0 \\
\hline 4 & $806-902$ & 0 & 0 & $1237-1333$ & 0 & 0 & $1333-1429$ & 0 & 0 \\
\hline 5 & 904-1039 & 0 & 0 & $1330-1426$ & 0 & 0 & $1650-1746$ & 0 & 0 \\
\hline 6 & $700-756$ & 0 & 0 & $1135-1231$ & 0 & 0 & $1340-1436$ & 0 & 0 \\
\hline 7 & $700-756$ & 0 & 0 & $1130-1226$ & 0 & 0 & $1345-1441$ & 0 & 0 \\
\hline 8 & $802-858$ & 0 & 0 & $1222-1318$ & 0 & 0 & $1318-1414$ & 0 & 0 \\
\hline 9 & $1030-1126$ & 0 & 0 & $1126-1222$ & 0 & 0 & $1715-1811$ & 0 & 0 \\
\hline 10 & $1012-1106$ & 0 & 0 & $1340-1436$ & 0 & 0 & $1600-1656$ & 0 & 0 \\
\hline 11 & $925-1021$ & 0 & 0 & $1146-1242$ & 0 & 0 & $1350-1446$ & 0 & 0 \\
\hline 12 & $925-1021$ & 0 & 0 & $1150-1246$ & 0 & 0 & $1354-1450$ & 0 & 0 \\
\hline 13 & $812-908$ & 0 & 0 & $1016-1112$ & 0 & 0 & $1542-1638$ & 0 & 0 \\
\hline 22 & $700-756$ & 0 & 0 & $1035-1131$ & 0 & 0 & $420-516$ & 0 & 0 \\
\hline 23 & $700-756$ & 0 & 0 & $1238-1334$ & 0 & 0 & $1442-1538$ & 0 & 0 \\
\hline 24 & $812-908$ & 0 & 0 & $1240-1336$ & 0 & 0 & $1336-1432$ & 0 & 0 \\
\hline 25 & $812-908$ & 0 & 0 & $1230-1326$ & 0 & 0 & $1326-1422$ & 0 & 0 \\
\hline 26 & $1013-1109$ & 0 & 0 & $1338-1434$ & 0 & 0 & $1700-1756$ & 0 & 0 \\
\hline 27 & $700-756$ & 0 & 0 & $1248-1344$ & 0 & 0 & $1344-1441$ & 0 & 0 \\
\hline 28 & $912-1008$ & 0 & 0 & $1138-1234$ & 0 & 0 & $1606-1702$ & 0 & 0 \\
\hline 29 & $700-756$ & 0 & 0 & $1242-1338$ & 0 & 0 & $1338-1434$ & 0 & 0 \\
\hline 30 & $800-856$ & 0 & 0 & $1350-1446$ & 1 & 1 & 1713-1809 & 0 & 0 \\
\hline 31 & $810-906$ & 0 & 0 & $1230-1326$ & 1 & 2 & $1430-1526$ & 1 & 2 \\
\hline 32 & $901-957$ & 0 & 0 & $1124-1220$ & 1 & 0 & $1446-1541$ & 1 & 0 \\
\hline 33 & $910-1006$ & 0 & 0 & $1332-1428$ & 0 & 0 & $1428-1524$ & 0 & 0 \\
\hline 34 & $802-858$ & 0 & 0 & $1026-1122$ & 0 & 0 & $1350-1446$ & 1 & 1 \\
\hline 35 & $801-857$ & 0 & 0 & $1024-1120$ & 0 & 0 & $1346-1442$ & 0 & 0 \\
\hline 36 & $700-756$ & 0 & 0 & $1241-1337$ & 0 & 0 & $1603-1659$ & 0 & 0 \\
\hline 37 & $1024-1120$ & 0 & 0 & $1228-1324$ & 0 & 0 & $1451-1547$ & 0 & 0 \\
\hline
\end{tabular}




\begin{tabular}{|c|c|c|c|c|c|c|c|c|c|}
\hline \multicolumn{10}{|c|}{ Long Point } \\
\hline \multirow{2}{*}{$\begin{array}{c}\text { Survey } \\
\text { Day }\end{array}$} & \multicolumn{3}{|c|}{ Round 1} & \multicolumn{3}{|c|}{ Round 2} & \multicolumn{3}{|c|}{ Round 3} \\
\hline & time & $\mathrm{VC}$ & $\mathrm{BA}$ & time & $\mathrm{VC}$ & $\mathrm{BA}$ & time & $\mathrm{VC}$ & $\mathrm{BA}$ \\
\hline 38 & $750-832$ & 30 & 0 & $1230-1312$ & 64 & 0 & 1404-1446 & 61 & 0 \\
\hline 39 & 934-1016 & 4 & 0 & $1117-1159$ & 7 & 0 & $1450-1532$ & 14 & 0 \\
\hline 40 & $1020-1116$ & 5 & 0 & $1116-1212$ & 5 & 0 & $1440-1536$ & 19 & 0 \\
\hline 41 & $700-756$ & 2 & 0 & $1020-1116$ & 3 & 0 & $1345-1441$ & 3 & 0 \\
\hline 42 & $911-1007$ & 33 & 0 & $1112-1208$ & 64 & 0 & $1433-1529$ & 64 & 0 \\
\hline 43 & 923-1019 & 12 & 0 & $1143-1239$ & 20 & 0 & $1605-1701$ & 9 & 0 \\
\hline 44 & $800-856$ & 8 & 0 & $1229-1325$ & 30 & 0 & $1448-1544$ & 16 & 0 \\
\hline 45 & $1020-1116$ & 12 & 0 & $1221-1317$ & 11 & 0 & $1443-1539$ & 8 & 0 \\
\hline 46 & $800-856$ & 19 & 0 & $1346-1442$ & 35 & 0 & $1442-1538$ & 47 & 0 \\
\hline 47 & $900-956$ & 15 & 0 & $1222-1318$ & 17 & 0 & $1545-1641$ & 17 & 0 \\
\hline 48 & $800-856$ & 12 & 0 & $1219-1315$ & 34 & 0 & $1640-1736$ & 21 & 0 \\
\hline 49 & $800-856$ & 14 & 0 & $1133-1229$ & 20 & 0 & $1703-1759$ & 7 & 0 \\
\hline 50 & $1012-1108$ & 90 & 0 & $1108-1204$ & 98 & 0 & $1430-1526$ & 83 & 0 \\
\hline 51 & $800-856$ & 3 & 0 & $1342-1438$ & 5 & 0 & $1438-1534$ & 6 & 0 \\
\hline 52 & $1000-1056$ & 64 & 0 & $1419-1515$ & 64 & 0 & $1718-1814$ & 33 & 0 \\
\hline 53 & $1222-1318$ & 31 & 0 & $1546-1642$ & 24 & 0 & $1810-1906$ & 14 & 0 \\
\hline 54 & $910-1006$ & 15 & 0 & $1112-1208$ & 27 & 0 & $1450-1546$ & 45 & 0 \\
\hline 55 & $800-856$ & 20 & 0 & $1322-1418$ & 34 & 0 & $1525-1621$ & 36 & 0 \\
\hline 56 & $1024-1120$ & 31 & 0 & $1120-1216$ & 37 & 0 & $1642-1738$ & 52 & 0 \\
\hline 57 & $902-958$ & 6 & 0 & $1224-1320$ & 11 & 0 & $1427-1523$ & 17 & 0 \\
\hline 58 & $901-957$ & 10 & 0 & $1341-1437$ & 25 & 0 & $1704-1800$ & 33 & 0 \\
\hline 59 & $903-959$ & 5 & 0 & $1350-1446$ & 12 & 0 & $1702-1758$ & 16 & 0 \\
\hline 60 & $901-957$ & 13 & 0 & $1323-1419$ & 33 & 0 & $1648-1744$ & 48 & 0 \\
\hline 61 & $1012-1108$ & 5 & 0 & $1337-1433$ & 2 & 0 & $1433-1529$ & 8 & 0 \\
\hline 62 & $1022-1118$ & 4 & 0 & $1235-1331$ & 4 & 0 & $1544-1640$ & 11 & 0 \\
\hline 63 & $800-856$ & 3 & 0 & $1342-1438$ & 2 & 0 & $1342-1438$ & 14 & 0 \\
\hline 64 & $800-856$ & 4 & 0 & $1226-1322$ & 15 & 0 & $1545-1641$ & 9 & 0 \\
\hline 65 & $800-856$ & 6 & 0 & $1222-1318$ & 4 & 0 & $1424-1520$ & 2 & 0 \\
\hline 66 & $1021-1117$ & 15 & 0 & $1117-1213$ & 28 & 0 & $1441-1537$ & 54 & 0 \\
\hline 67 & $1011-1107$ & 8 & 0 & $1346-1442$ & 19 & 0 & $1710-1806$ & 15 & 0 \\
\hline 68 & $800-856$ & 4 & 0 & $1350-1446$ & 1 & 0 & $1715-1811$ & 4 & 0 \\
\hline 69 & $1021-1117$ & 4 & 0 & $1117-1213$ & 0 & 0 & $1544-1640$ & 0 & 0 \\
\hline 70 & $800-856$ & 4 & 0 & $1346-1442$ & 2 & 0 & $1608-1704$ & 3 & 0 \\
\hline 71 & $800-856$ & 4 & 0 & $1340-1426$ & 13 & 0 & $1642-1738$ & 3 & 0 \\
\hline 72 & $1011-1107$ & 6 & 0 & $1335-1431$ & 8 & 0 & $1431-1527$ & 0 & 0 \\
\hline 73 & $800-856$ & 2 & 0 & $1218-1314$ & 2 & 0 & $1430-1526$ & 0 & 0 \\
\hline 74 & $900-956$ & 2 & 0 & $1120-1216$ & 2 & 0 & $1542-1638$ & 3 & 0 \\
\hline 76 & $1020-1116$ & 1 & 0 & $1222-1318$ & 1 & 0 & $1540-1636$ & 1 & 0 \\
\hline 77 & $800-856$ & 4 & 0 & $1320-1416$ & 3 & 0 & $1416-1512$ & 3 & 0 \\
\hline 78 & $1012-1108$ & 7 & 0 & $1225-1321$ & 5 & 0 & $1646-1742$ & 5 & 0 \\
\hline 79 & $912-1008$ & 2 & 0 & $1113-1209$ & 0 & 0 & $1436-1532$ & 4 & 0 \\
\hline 81 & $800-856$ & 4 & 0 & 1123-1219 & 6 & 0 & $1547-1643$ & 2 & 0 \\
\hline 82 & $800-856$ & 94 & 0 & $1330-1426$ & 92 & 0 & $1440-1536$ & 0 & 0 \\
\hline 83 & 1013-1109 & 3 & 0 & $1237-1333$ & 6 & 0 & $1439-1535$ & 4 & 1 \\
\hline 84 & 910-1006 & 10 & 0 & $1111-1208$ & 10 & 0 & $1542-1638$ & 6 & 0 \\
\hline 85 & $900-956$ & 2 & 0 & $1343-1439$ & 4 & 0 & $1707-1803$ & 0 & 0 \\
\hline 86 & $800-856$ & 4 & 0 & $1318-1414$ & 2 & 0 & $1641-1737$ & 3 & 1 \\
\hline
\end{tabular}




\begin{tabular}{|c|c|c|c|c|c|c|c|c|c|}
\hline \multirow{2}{*}{$\begin{array}{c}\text { Survey } \\
\text { Day }\end{array}$} & \multicolumn{3}{|c|}{ Round 1} & \multicolumn{3}{|c|}{ Round 2} & \multicolumn{3}{|c|}{ Round 3} \\
\hline & time & $\mathrm{VC}$ & BA & time & $\mathrm{VC}$ & BA & time & $\mathrm{VC}$ & BA \\
\hline 1 & $820-900$ & 0 & 0 & $1155-1235$ & 0 & 0 & $1515-1555$ & 1 & 0 \\
\hline 2 & $836-932$ & 0 & 0 & $1057-1153$ & 1 & 0 & $1425-1521$ & 2 & 0 \\
\hline 3 & $941-1037$ & 0 & 0 & $1311-1407$ & 0 & 0 & $1530-1626$ & 0 & 0 \\
\hline 4 & $700-756$ & 0 & 0 & $1023-1119$ & 2 & 0 & $1435-1531$ & 0 & 0 \\
\hline 5 & $840-936$ & 0 & 0 & $1046-1142$ & 0 & 0 & $1430-1526$ & 1 & 0 \\
\hline 6 & 914-1010 & 0 & 0 & $1238-1334$ & 3 & 3 & $1600-1656$ & 0 & 0 \\
\hline 7 & $806-902$ & 0 & 0 & $1026-1122$ & 0 & 0 & $1450-1546$ & 0 & 0 \\
\hline 8 & $700-756$ & 0 & 0 & $1120-1216$ & 0 & 0 & $1605-1701$ & 2 & 0 \\
\hline 9 & $800-856$ & 0 & 0 & $1230-1326$ & 0 & 0 & $1453-1549$ & 0 & 0 \\
\hline 10 & 911-1007 & 0 & 0 & $1113-1209$ & 0 & 0 & $1700-1756$ & 0 & 0 \\
\hline 11 & $702-758$ & 0 & 0 & $1248-1344$ & 0 & 0 & $1452-1548$ & 0 & 0 \\
\hline 12 & $701-757$ & 0 & 0 & $1251-1347$ & 0 & 0 & $1615-1711$ & 0 & 0 \\
\hline 13 & 915-1011 & 0 & 0 & $1118-1214$ & 0 & 0 & $1440-1537$ & 0 & 0 \\
\hline 22 & $810-906$ & 0 & 0 & $1136-1232$ & 0 & 0 & $1400-1456$ & 0 & 0 \\
\hline 23 & 923-1019 & 0 & 0 & $1019-1115$ & 0 & 0 & $140-236$ & 0 & 0 \\
\hline 24 & $915-1011$ & 0 & 0 & $1137-1233$ & 0 & 0 & $1600-1656$ & 0 & 0 \\
\hline 25 & 913-1009 & 0 & 0 & $1009-1105$ & 0 & 0 & $1548-1644$ & 0 & 0 \\
\hline 26 & 911-1007 & 0 & 0 & $1237-1333$ & 0 & 0 & $1440-1536$ & 0 & 0 \\
\hline 27 & 923-1019 & 0 & 0 & $1145-1241$ & 0 & 0 & $1604-1700$ & 0 & 0 \\
\hline 28 & $700-756$ & 0 & 0 & $1240-1336$ & 2 & 0 & $1503-1559$ & 0 & 0 \\
\hline 29 & 923-1019 & 2 & 0 & $1136-1232$ & 3 & 0 & $1600-1656$ & 4 & 0 \\
\hline 30 & $902-958$ & 0 & 0 & $1126-1222$ & 0 & 0 & 1611-1708 & 0 & 0 \\
\hline 31 & 911-1007 & 0 & 0 & $1007-1103$ & 0 & 0 & $1330-1426$ & 3 & 0 \\
\hline 32 & $800-856$ & 1 & 0 & $1345-1441$ & 7 & 0 & $1546-1642$ & 7 & 0 \\
\hline 33 & $1011-1108$ & 0 & 0 & $1108-1204$ & 0 & 0 & $1651-1747$ & 1 & 0 \\
\hline 34 & $700-756$ & 2 & 0 & $1249-1345$ & 3 & 0 & $1450-1546$ & 0 & 0 \\
\hline 35 & $700-756$ & 1 & 0 & $1245-1341$ & 2 & 0 & $1448-1544$ & 0 & 0 \\
\hline 36 & $920-1016$ & 4 & 1 & $1140-1236$ & 4 & 0 & $1502-1558$ & 4 & 0 \\
\hline 37 & $800-856$ & 0 & 0 & $1126-1222$ & 0 & 0 & $1552-1648$ & 0 & 0 \\
\hline 38 & $945-1027$ & 2 & 0 & $1317-1359$ & 2 & 0 & $1559-1641$ & 2 & 0 \\
\hline 39 & $847-929$ & 5 & 0 & $1404-1446$ & 15 & 0 & $1537-1619$ & 7 & 0 \\
\hline 40 & $800-856$ & 2 & 0 & $1340-1436$ & 4 & 0 & $1541-1637$ & 9 & 1 \\
\hline 41 & $920-1016$ & 1 & 0 & $1122-1218$ & 1 & 0 & 1606-1702 & 0 & 0 \\
\hline 42 & $1012-1108$ & 28 & 1 & $1333-1429$ & 26 & 2 & $1534-1630$ & 17 & 0 \\
\hline 43 & $700-756$ & 4 & 0 & $1245-1341$ & 7 & 0 & $1505-1601$ & 2 & 1 \\
\hline 44 & 903-959 & 1 & 1 & $1128-1224$ & 1 & 1 & $1710-1806$ & 2 & 0 \\
\hline 45 & $800-856$ & 3 & 0 & $1120-1216$ & 4 & 0 & $1706-1802$ & 1 & 0 \\
\hline 46 & $1024-1120$ & 9 & 0 & $1246-1342$ & 13 & 0 & $1543-1639$ & 15 & 0 \\
\hline 47 & $800-856$ & 4 & 0 & $1121-1217$ & 9 & 0 & $1444-1540$ & 12 & 0 \\
\hline 48 & $900-956$ & 8 & 0 & $1320-1416$ & 13 & 0 & $1416-1512$ & 15 & 0 \\
\hline 49 & $1022-1118$ & 9 & 0 & $1345-1441$ & 12 & 0 & $1441-1537$ & 10 & 0 \\
\hline 50 & $911-1007$ & 20 & 0 & $1330-1426$ & 25 & 1 & $1652-1748$ & 17 & 0 \\
\hline
\end{tabular}




\begin{tabular}{cccccccccc}
51 & $1023-1119$ & 0 & 0 & $1119-1215$ & 2 & 0 & $1700-1756$ & 3 & 0 \\
52 & $1100-1156$ & 15 & 1 & $1520-1616$ & 45 & 2 & $1616-1712$ & 29 & 2 \\
53 & $1000-1056$ & 11 & 0 & $1445-1541$ & 12 & 0 & $1911-2007$ & 9 & 0 \\
54 & $1011-1107$ & 9 & 0 & $1214-1310$ & 15 & 0 & $1712-1808$ & 17 & 0 \\
55 & $902-958$ & 6 & 0 & $1222-1318$ & 17 & 0 & $1423-1519$ & 19 & 3 \\
56 & $800-856$ & 4 & 0 & $1221-1317$ & 12 & 1 & $1540-1636$ & 32 & 2 \\
57 & $800-856$ & 2 & 0 & $1325-1421$ & 5 & 0 & $1647-1743$ & 9 & 0 \\
58 & $800-856$ & 4 & 0 & $117-1213$ & 6 & 0 & $1443-1539$ & 12 & 0 \\
59 & $800-856$ & 0 & 0 & $1126-1222$ & 5 & 0 & $1610-1706$ & 18 & 0 \\
60 & $800-856$ & 2 & 0 & $1222-1318$ & 11 & 0 & $1546-1642$ & 16 & 2 \\
61 & $910-1006$ & 1 & 0 & $1114-1210$ & 3 & 0 & $1654-1750$ & 3 & 0 \\
62 & $800-856$ & 0 & 1 & $1347-1443$ & 3 & 0 & $1443-1539$ & 4 & 0 \\
63 & $1020-1116$ & 2 & 0 & $1231-1337$ & 3 & 0 & $1603-1659$ & 5 & 0 \\
64 & $902-958$ & 4 & 0 & $1125-1221$ & 9 & 0 & $1646-1742$ & 11 & 0 \\
65 & $903-959$ & 1 & 0 & $1323-1419$ & 2 & 0 & $1525-1621$ & 2 & 0 \\
66 & $800-856$ & 2 & 0 & $1218-1314$ & 9 & 0 & $1543-1639$ & 14 & 1 \\
67 & $910-1006$ & 2 & 0 & $1245-1341$ & 0 & 0 & $1446-1542$ & 4 & 0 \\
68 & $902-958$ & 4 & 1 & $1127-1223$ & 2 & 0 & $1452-1548$ & 3 & 0 \\
69 & $800-856$ & 1 & 0 & $1218-1314$ & 3 & 1 & $1441-1537$ & 1 & 0 \\
70 & $901-957$ & 2 & 0 & $1124-1220$ & 3 & 0 & $1709-1805$ & 0 & 0 \\
71 & $1021-1117$ & 2 & 0 & $1117-1213$ & 1 & 0 & $1431-1527$ & 16 & 0 \\
72 & $910-1006$ & 2 & 0 & $1234-1330$ & 8 & 0 & $1532-1628$ & 2 & 0 \\
73 & $1021-1117$ & 3 & 0 & $1117-1213$ & 2 & 0 & $1531-1627$ & 2 & 0 \\
74 & $800-856$ & 2 & 0 & $1221-1317$ & 2 & 0 & $1441-1537$ & 2 & 0 \\
75 & $800-856$ & 5 & 0 & $1121-1217$ & 5 & 0 & $1641-1737$ & 0 & 0 \\
76 & $900-956$ & 0 & 0 & $1218-1314$ & 0 & 0 & $1517-1613$ & 1 & 0 \\
77 & $800-856$ & 3 & 0 & $1113-1209$ & 2 & 0 & $1545-1641$ & 0 & 2 \\
78 & $1012-1108$ & 0 & 0 & $1214-1310$ & 0 & 0 & $1537-1633$ & 2 & 0 \\
79 & $900-956$ & 0 & 0 & $1224-1320$ & 0 & 0 & $1446-1542$ & 0 & 0 \\
80 & $1021-1117$ & 3 & 0 & $1117-1213$ & 0 & 0 & $1541-1637$ & 0 & 0 \\
81 & $911-1007$ & 2 & 0 & $1338-1434$ & 1 & 0 & $1700-1756$ & 0 & 0 \\
82 & $1011-1106$ & 3 & 0 & $1213-1309$ & 0 & 3 & $1644-1740$ & 0 & 0 \\
83 & $800-856$ & 0 & 0 & $1121-1217$ & 1 & 0 & $1606-1702$ & 0 & 0 \\
84 & $900-956$ & 2 & 0 & $1217-1313$ & 2 & 0 & $1540-1636$ & 0 & 0 \\
\hline
\end{tabular}

Winter Ramp 


\begin{tabular}{|c|c|c|c|c|c|c|c|c|c|}
\hline \multirow{2}{*}{$\begin{array}{c}\text { Survey } \\
\text { Day }\end{array}$} & \multicolumn{3}{|c|}{ Round 1} & \multicolumn{3}{|c|}{ Round 2} & \multicolumn{3}{|c|}{ Round 3} \\
\hline & time & $\mathrm{VC}$ & BA & time & $\mathrm{VC}$ & BA & time & $\mathrm{VC}$ & BA \\
\hline 1 & $730-810$ & 5 & 0 & $1100-1140$ & 0 & 0 & $1425-1505$ & 10 & 0 \\
\hline 2 & $946-1042$ & 1 & 0 & $1207-1303$ & 1 & 0 & $1533-1629$ & 0 & 0 \\
\hline 3 & $835-931$ & 0 & 0 & $1050-1146$ & 0 & 0 & $1420-1516$ & 0 & 0 \\
\hline 4 & $917-1013$ & 3 & 0 & $1127-1223$ & 2 & 0 & $1545-1641$ & 0 & 0 \\
\hline 5 & $730-826$ & 1 & 0 & $1157-1253$ & 1 & 0 & $1540-1636$ & 5 & 1 \\
\hline 6 & $805-901$ & 1 & 0 & $1025-1121$ & 2 & 0 & $1450-1546$ & 0 & 0 \\
\hline 7 & $917-1013$ & 0 & 0 & $1236-1332$ & 0 & 0 & $1600-1656$ & 0 & 0 \\
\hline 8 & $915-1011$ & 1 & 0 & $1011-1107$ & 1 & 0 & $1500-1556$ & 5 & 0 \\
\hline 9 & $910-1006$ & 0 & 0 & $1341-1437$ & 1 & 0 & $1604-1700$ & 0 & 0 \\
\hline 10 & $800-856$ & 0 & 0 & $1227-1324$ & 2 & 1 & $1450-1546$ & 1 & 1 \\
\hline 11 & $814-910$ & 0 & 0 & $1035-1131$ & 0 & 0 & $1605-1701$ & 0 & 0 \\
\hline 12 & 813-909 & 0 & 0 & $1040-1136$ & 0 & 0 & $1507-1603$ & 0 & 0 \\
\hline 13 & $700-756$ & 0 & 0 & $1230-1326$ & 0 & 0 & $1326-1424$ & 0 & 0 \\
\hline 22 & $917-1013$ & 0 & 0 & $1250-1346$ & 0 & 0 & $1510-1606$ & 0 & 0 \\
\hline 23 & $812-908$ & 0 & 0 & $1126-1222$ & 0 & 0 & $1552-1648$ & 0 & 0 \\
\hline 24 & $700-756$ & 0 & 0 & $1025-1121$ & 0 & 0 & $1446-1542$ & 0 & 0 \\
\hline 25 & $700-756$ & 2 & 0 & $1120-1216$ & 5 & 0 & $1437-1533$ & 5 & 0 \\
\hline 26 & $800-856$ & 0 & 0 & $1125-1221$ & 0 & 0 & $1550-1646$ & 0 & 0 \\
\hline 27 & $812-908$ & 0 & 0 & $1033-1129$ & 0 & 0 & $1455-1551$ & 0 & 0 \\
\hline 28 & $810-906$ & 2 & 0 & 1024-1121 & 6 & 0 & $1350-1446$ & 5 & 0 \\
\hline 29 & $812-908$ & 2 & 0 & $1033-1129$ & 2 & 0 & $1450-1546$ & 3 & 0 \\
\hline 30 & $1015-1111$ & 4 & 0 & $1238-1334$ & 5 & 0 & $1500-1556$ & 4 & 0 \\
\hline 31 & $700-756$ & 1 & 0 & $1118-1214$ & 4 & 0 & $1540-1636$ & 0 & 0 \\
\hline 32 & $1012-1108$ & 5 & 0 & $1235-1331$ & 8 & 0 & $1558-1754$ & 6 & 0 \\
\hline 33 & $800-856$ & 0 & 0 & $1220-1316$ & 2 & 0 & $1540-1636$ & 4 & 0 \\
\hline 34 & $904-1010$ & 2 & 0 & $1137-1233$ & 4 & 0 & $1600-1656$ & 3 & 0 \\
\hline 35 & $912-1008$ & 1 & 0 & $1135-1231$ & 1 & 0 & $1600-1656$ & 0 & 0 \\
\hline 36 & $810-906$ & 5 & 0 & $1030-1124$ & 8 & 0 & $1351-1447$ & 0 & 0 \\
\hline 37 & $912-1008$ & 0 & 0 & $1341-1437$ & 0 & 0 & $1702-1748$ & 0 & 0 \\
\hline 79 & $1011-1107$ & 0 & 0 & $1335-1431$ & 0 & 0 & $1700-1754$ & 0 & 0 \\
\hline 80 & $910-1006$ & 3 & 0 & $1218-1314$ & 0 & 0 & $1652-1748$ & 2 & 0 \\
\hline 81 & $800-856$ & 1 & 0 & $1126-1222$ & 1 & 0 & $1550-1646$ & 0 & 0 \\
\hline 82 & $800-856$ & 1 & 0 & $1336-1432$ & 0 & 0 & $1432-1528$ & 2 & 0 \\
\hline 83 & $1010-1106$ & 0 & 0 & $1232-1328$ & 0 & 0 & $1455-1551$ & 0 & 0 \\
\hline 84 & $1010-1106$ & 1 & 0 & $1106-1202$ & 1 & 0 & $1430-1526$ & 3 & 0 \\
\hline
\end{tabular}

John H. Virginia University Libraries, 